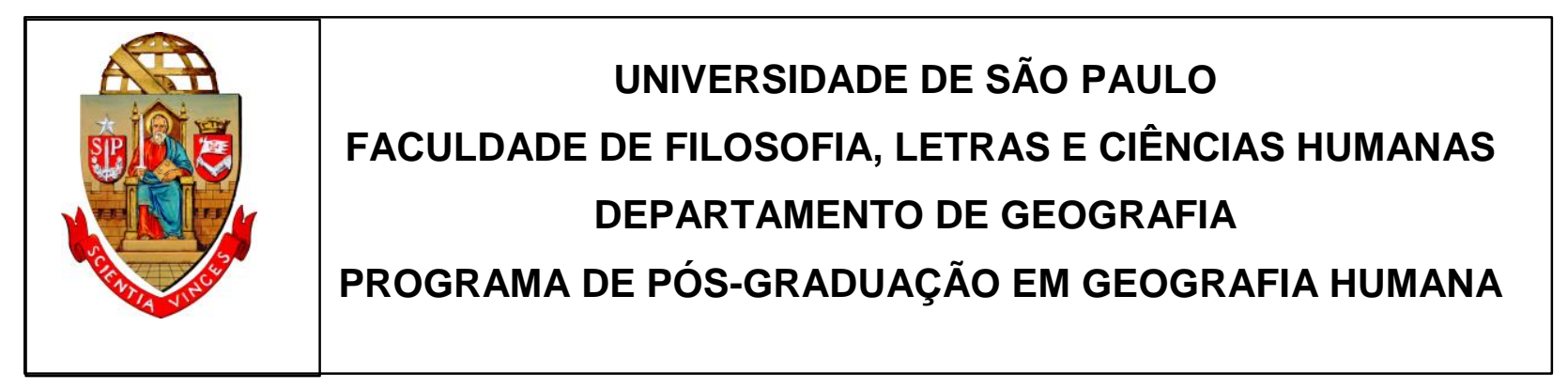

Fabiano Leite da Silva

METRÓPOLE CORPORATIVA E FRAGMENTADA: A URBANIZAÇÃO DA PENÍNSULA DO RIBEIRÃO COCAIA, GRAJAÚ, EM SÃO PAULO

Versão corrigida

SÃO PAULO

2016 
Fabiano Leite da Silva

\title{
METRÓPOLE CORPORATIVA E FRAGMENTADA: A URBANIZAÇÃO DA PENÍNSULA DO RIBEIRÃO COCAIA, GRAJAÚ, EM SÃO PAULO
}

\author{
Versão corrigida
}

Dissertação apresentada ao Programa de PósGraduação em Geografia Humana do Departamento de Geografia da Faculdade de Filosofia, Letras e Ciências Humanas da Universidade de São Paulo, para obtenção do título de Mestre em Geografia.

Área de concentração: Geografia Humana

Orientador: Prof. Dr. Fabio Betioli Contel

SÃO PAULO

2016 
Autorizo a reprodução e divulgação total ou parcial deste trabalho, por qualquer meio convencional ou eletrônico, para fins de estudo e pesquisa, desde que citada a fonte.

Catalogação na Publicação

Serviço de Biblioteca e Documentação

Faculdade de Filosofia, Letras e Ciências Humanas da Universidade de São Paulo

Silva, Fabiano Leite da

Metrópole corporativa e fragmentada: a urbanização da Península do Ribeirão Cocaia, Grajaú, em São Paulo / Fabiano Leite da Silva ; orientador Fabio Betioli Contel. - São Paulo, 2016.

$149 \mathrm{f}$.

Dissertação (Mestrado) - Faculdade de Filosofia, Letras e Ciências Humanas da Universidade de São Paulo. Departamento de Geografia. Área de concentração: Geografia Humana.

1. CH732.5 - Urbanização. 2. CE530.1.20.1.11.1 Mananciais. 3. CE530.1.20.1.11 - Recursos hídricos. 4. CH732.3 - Planejamento territorial urbano. 5. CH732.3.20.1 - Loteamento clandestino. I. Contel, Fabio Betioli, orient. II. Título. 
LEITE, F. L. da. Metrópole corporativa e fragmentada: a urbanização da Península do Ribeirão Cocaia, Grajaú, em São Paulo. Dissertação apresentada à Faculdade de Filosofia, Letras e Ciências Humanas da Universidade de São Paulo para obtenção do título de Mestre em Geografia.

Aprovado em: 21 de setembro de 2016

Banca examinadora

Prof. Dr. Fabio Betioli Contel (Orientador)

Julgamento:

Prof. Dr. Ricardo Mendes Antas Junior

Julgamento:

Prof. Dr. Vicente Eudes Lemos

Julgamento:
Instituição: Departamento de Geografia FFLCH - USP

Assinatura:

Instituição: Departamento de Geografia FFLCH - USP

Assinatura:

Instituição: Instituto de Geografia da Unicamp

Assinatura: 
Dedico este trabalho a todos aqueles que têm o desejo de conhecer a sociedade em que vivem, compreendê-la e transformá-la em um lugar melhor. $\mathrm{E}$ a todos que acreditam e lutam por mais justiça social. 


\section{Agradecimentos}

A Deus, por existir. Aos meus pais, Ursina e Luiz, por me fazerem acreditar no caminho do estudo. À minha querida esposa Tereza Cristina, pelo amor, pela paciência infinita e por todos os incentivos recebidos durante a realização desta obra. Aos filhos, Fabio e Juan, pelo apoio, pela solidariedade e compreensão. A Fernando Vedovate, pela amizade e generosidade inquestionáveis. Ao meu orientador, por acreditar nesta ideia e por ter-me dado a oportunidade para elaborar este trabalho.

Aos entrevistados: Cleide, presidente da Associação de Moradores do Grajaú; Maria Vilani, escritora e moradora do Grajaú; Claudio Canõn, presidente da Associação de Moradores do Parque Residencial Cocaia; Marcelo, professor coordenador da CEU EMEF Cantinho do Céu; Renato Rosseti, técnico da Cetesb; Márcia Nascimento, arquiteta, técnica da Secretaria de Recursos Hídricos; funcionários da Secretaria do Verde e Meio Ambiente da Prefeitura Municipal de São Paulo: Diego, geógrafo, diretor do Parque Natural do Itaim; Alice, bióloga, gestora da Área de Proteção Ambiental Bororé-Colônia; Ricardo, gestor ambiental do Parque Municipal Bororé; Fernando (Flash), Ocupação Anchieta Grajaú; Anderson Fernandes, Ocupação Anchieta Grajaú; Sandro Mambelli, presidente da Associação de Moradores do Cantinho do Céu; Josiane, líder comunitária do Cantinho do Céu; Joana, líder comunitária da Comunidade Sucupira no Grajaú, e Jaí, do coletivo Imargem/Ecoativa. A todos vocês, muito obrigado pela confiança. 


\section{Resumo}

LEITE, F. L. da. Metrópole corporativa e fragmentada: a urbanização da Península do Ribeirão Cocaia, Grajaú, em São Paulo. Dissertação (Mestrado) — Faculdade de Filosofia, Letras e Ciências Humanas, Universidade de São Paulo, São Paulo, 2016.

O presente trabalho tem por objetivo discutir e problematizar a ocupação de uma área de manancial inserida na Zona Sul da cidade de São Paulo, a Península do Ribeirão Cocaia. Para a discussão desse processo, trabalhou-se com a relação entre diferentes escalas, associando processos mais gerais da metropolização da cidade de São Paulo e a constituição da metrópole corporativa e mostrando como isso refletiu de forma decisiva nesse importante lugar da cidade, que havia sido, em um determinado momento, concebido como um importante espaço estratégico de conservação dos recursos hídricos, mas que veio a se transformar em um espaço principalmente de moradia de trabalhadores de baixa renda. Em que pesem as transformações recentes com a melhoria de alguns bairros na Península do Ribeirão Cocaia, ainda existem áreas de grande precariedade nessa região. Dessa maneira, realizou-se um recorte espacial de três bairros que constituem a Península: o Grajaú, no período da instalação da Cohab Bororé, nos anos 1970; o Parque Residencial Cocaia, com base em loteamentos clandestinos nos anos 1980; e o Cantinho do Céu, com a intensificação da ocupação a partir dos anos 1990. Este trabalho problematiza a questão do uso e da ocupação de áreas de mananciais, refletindo como se deu esse processo e o que tem sido feito até agora, procurando chamar a atenção das autoridades e da população para esse fato tão preocupante.

Palavras chave: Mananciais, Urbanização, Península do Ribeirão Cocaia, Grajaú, Cantinho do Céu, Parque Residencial Cocaia, Ocupação Anchieta, Parque Linear, Espoliação Urbana, Espoliação Ambiental. 


\begin{abstract}
LEITE, Fabiano Leite da. Metrópole corporativa e fragmentada: a urbanização da Península do Ribeirão Cocaia, Grajaú, em São Paulo. Dissertação (Mestrado) - Faculdade de Filosofia, Letras e Ciências Humanas, Universidade de São Paulo, São Paulo, 2016.
\end{abstract}

This paper discuss the occupation of a watershed area that is inserted in the South Zone of São Paulo, Ribeirão Cocaia Peninsula. To discuss this process sought to work with the relation between different scales, relating more general process of expansion of the city of São Paulo, and the establishment of corporate metropolis and how it reflected in this important area of the city, which had been considered as an important strategic area of conservation of water resources and that turned into a mostly housing low-income workers. Despite the recent changes with the improvement of parts of some neighborhoods in Ribeirão Cocaia peninsula, there are still areas of great precariousness in this space of the city. In this way we tried to make a spatial area three districts that make up the Peninsula: The Grajaú, during the installation of Cohab Bororé in the 70s; the Cocaia Residential Park, based in illegal settlements in the 1980s, and the Corner of Heaven, where the occupancy gains strength in the 1990s. This paper discusses the question of the use and occupation of watershed areas, reflecting on how this process took place, and what has been done so far, trying to draw attention to this issue.

Key Words: Spring, Urbanization, Península of Cocaia's Stream, Grajaú, Cantinho do Céu, Parque residencial Cocaia, Anchieta's Occupation, Parque Linear, Urban Exploitation, Environmental Exploitation. 
Lista de figuras

Figura 1 - Região Metropolitana de São Paulo 16

Figura 2 - Divisão de subprefeituras do município de São Paulo 16

Figura 3 - Represa Billings, em São Paulo 17

Figura 4 - Modelo tridimensional da Península do Ribeirão Cocaia, Parque Residencial Cocaia, Parque Recanto Cocaia, Grajaú, Cantinho do Céu e adjacências 20

Figura 5 - Palácio dos Campos Elíseos 26

Figura 6 - Brás: antiga Ladeira do Carmo (atual Rangel Pestana) 26

Figura 7 - Ponte sobre o rio Grande, em Santo Amaro 28

Figura 8 - Antigo Mercado Municipal de Santo Amaro 30

Figura 9 - Obras durante a construção da barragem do reservatório Gurapiranga 37

Figura 10 - Usina Elevatória de Pedreira 38

Figura 11 - Pedra inaugural da Usina Hidrelétrica Henry Borden, localizada no sopé da Serra do Mar, em Cubatão $\quad 40$

Figura 12 - Conjunto Presidente Getúlio Vargas, Deodoro, Rio de Janeiro 43

Figura 13 - Veículo de abastecimento de água na Cohab Bororé 67

Figura 14 - Linha de ônibus Grajaú 69

Figura 15 - Rua São José do Rio Preto, no Grajaú $\quad 70$

Figura 16 - Caminhão da Cobal

Figura 17 - Ônibus da Viação Bola Branca, no Grajaú 72

Figura 18 - Prédios da Cohab Grajaú $\quad 73$

Figura 19 - População absoluta dos distritos de São Paulo - 1970

Figura 20 - Cantinho do Céu e Represa Billings $\quad 80$

Figura 21 - População absoluta dos distritos de São Paulo - 1980

Figura 22 - População absoluta dos distritos de São Paulo - 1991

Figura 23 - População absoluta dos distritos de São Paulo - 2000

Figura 24 - População absoluta dos distritos de São Paulo - 2014

Figura 25 - Cantinho do Céu 95

Figura 26 - Cantinho do Céu 96

Figura 27 - Morador de rua dormindo em praça do Grajaú $\quad 97$

Figura 28 - Construções próximas da estação de trem da CPTM do Grajaú 100

Figura 29 - Comunidade Sucupira $\quad 102$

Figura 30 - Esgoto a céu aberto na Comunidade Sucupira 106

Figura 31 - Foco de contaminação em córrego da Comunidade Sucupira 106

Figura 32 - Ocupação Anchieta $\quad 110$

$\begin{array}{ll}\text { Figura } 33 \text { - Parque linear } & 118\end{array}$ 
Lista de tabelas

Tabela 1. Aumento absoluto da população da Subprefeitura da Capela do Socorro em relação a São Paulo (1950-2010)

Tabela 2. Relação das taxas de crescimento populacional entre o Município $\begin{array}{ll}\text { de São Paulo e o Subdistrito de Grajaú (1960-2010) } & 19\end{array}$

Tabela 3. População da cidade de São Paulo

Tabela 4. Distribuição dos domicílios segundo o tipo de ocupação na cidade de São Paulo (1920-2010)

Tabela 5. Domicílios ligados ou não à rede de esgoto - 2010

Tabela 6. Cantinho do Céu: população segundo faixas etárias

Lista de gráficos

Gráfico 1 - População do Município de São Paulo - 1872-2016

Gráfico 2 - Evolução do salário mínimo (em R\$̣)

Gráfico 3 - Perfil de investimentos de prefeitos de São Paulo 


\section{Lista de siglas}

APM Área de Proteção de Mananciais

CDHU Companhia de Desenvolvimento Habitacional e Urbano do Estado de São Paulo

CETESB Companhia de Tecnologia de Saneamento Ambiental

COHAB Companhia Metropolitana de Habitação

COHAB-SP Companhia Metropolitana de Habitação de São Paulo

CPTM Companhia Paulista de Trens Metropolitanos

EMPLASA Empresa de planejamento do Governo do Estado de São Paulo

FCP Fundação Casa Popular

IAPS Instituto de Aposentadorias e Pensões

MMV Minha Casa Minha Vida

OMS Organização Mundial da Saúde

PMDI Plano Metropolitano de Desenvolvimento Integrado

SEADE Fundação Sistema Estadual de Análise de Dados

SMA Secretaria do Meio Ambiente

SMDU Secretária Municipal de Desenvolvimento Urbano

SUS Sistema Único de Saúde 


\section{Sumário}

Introdução.

Objetivos da pesquisa e pressupostos teórico-metodológicos ........................................................... 21

Capítulo 1: Crescimento da cidade de São Paulo e expansão para a Zona Sul .....................................25

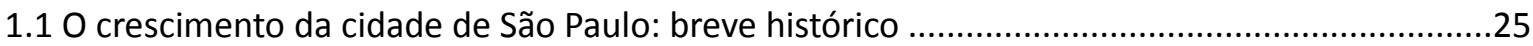

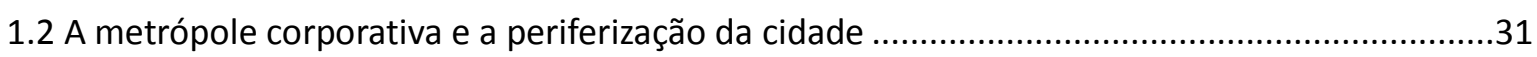

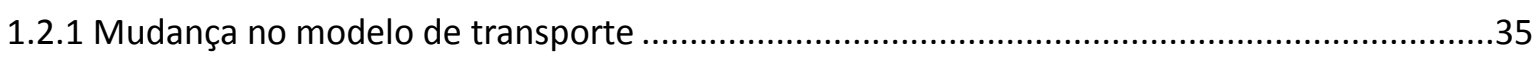

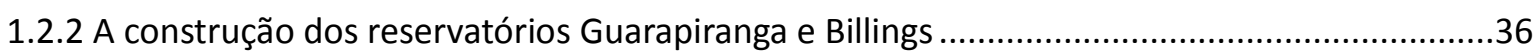

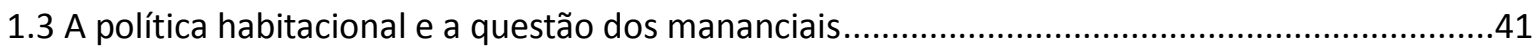

1.3.1 A questão da habitação no período anterior aos anos 1970 ..................................................

1.3.2 As alternativas habitacionais dos anos 1970 e a ocupação das áreas de proteção aos

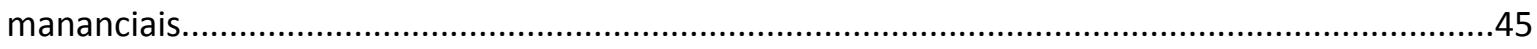

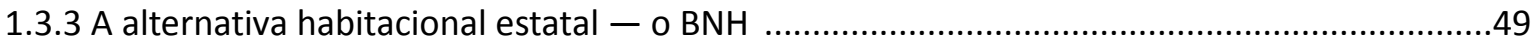

1.4 As áreas de proteção de mananciais: normas e formas de ocupação ...........................................51

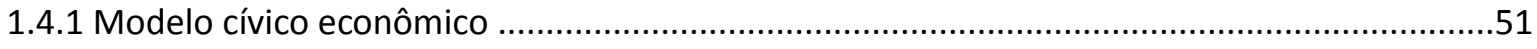

1.4.2 A questão da normatização dos anos 1970 com as leis específicas de áreas de proteção aos

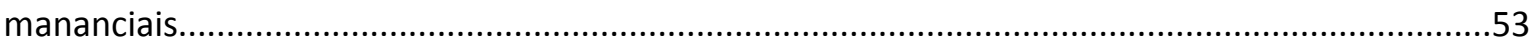

1.4.3 As duas agendas políticas que "não se encontram" ................................................................56

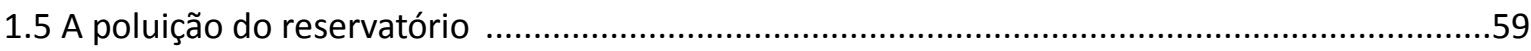

Capítulo 2: Urbanização, políticas habitacionais e formação da Península do Ribeirão Cocaia .......65

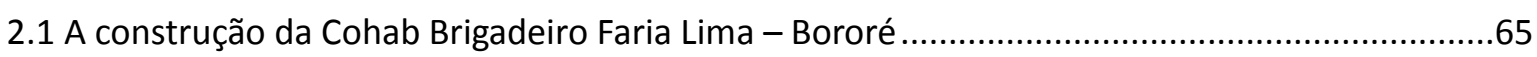

2.2 A formação dos bairros Parque Residencial Cocaia e Cantinho do Céu .......................................73

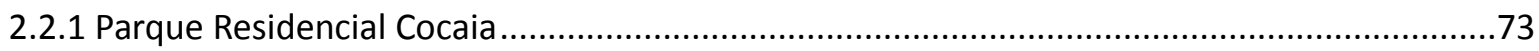

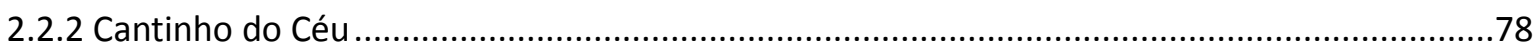

2.3 Década de 1990: agudização dos problemas urbanos na periferia ...........................................83

Capítulo 3: Equipamentos urbanos e condições de vida na Península do Ribeirão Cocaia ...............92

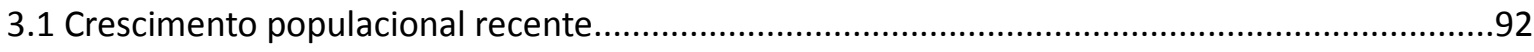

3.2 Condições de saúde, habitação e saneamento urbano ............................................................98

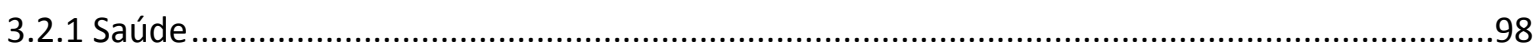

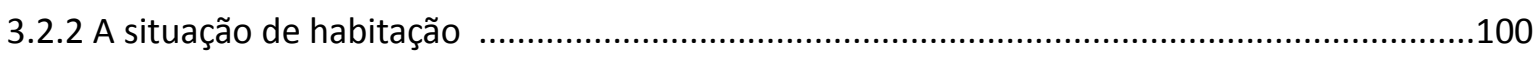

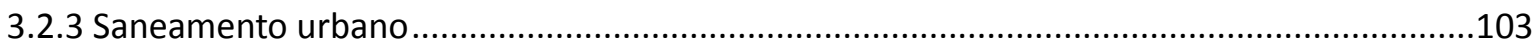

3.3 Contradições recentes na organização do espaço nas áreas de proteção de mananciais: Ocupação Anchieta e parque linear Cantinho do Céu ...............................................................108

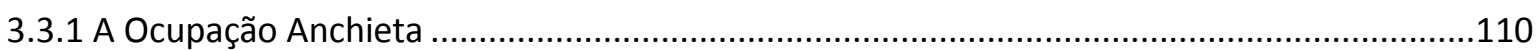

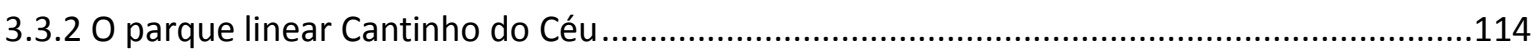


Considerações finais

Referências bibliográficas

Anexos

LEI no 898, de 18 de dezembro de 1975

LEI no 898, de 18 de dezembro de 1975 


\section{Introdução}

O presente trabalho visa discutir como se deu o processo de urbanização da cidade de São Paulo, com destaque para seu avanço nas áreas de proteção aos mananciais, com foco específico na Península do Ribeirão Cocaia, subdistrito do Grajaú, que apresentou as maiores taxas de crescimento de toda a cidade nos anos 1990, apesar das proibições legais impostas por uma legislação extremamente restritiva de uso e ocupação do solo nas áreas de proteção aos mananciais.

Esse processo de crescimento só pode ser compreendido dentro de um contexto maior que envolve a urbanização brasileira, e, dentro desta, a formação da metrópole corporativa fragmentada (SANTOS, 1990) desde os anos 1950, que significou a construção de uma metrópole organizada para satisfazer principalmente às necessidades das grandes empresas multinacionais, com a estruturação de um espaço funcional de circulação das mercadorias e não necessariamente voltada aos cidadãos.

A maior parte da população metropolitana nunca consistiu de fato na principal preocupação dos planos governamentais, passando pelo modelo cívico econômico instituído a partir de 1964, até meados dos anos 1980 - um modelo que castrava as liberdades políticas e se baseava no crescimento econômico e na concentração de renda - , até desembocarmos na reestruturação produtiva e nas políticas neoliberais dos anos 1990. Essas políticas de reestruturação, por sua vez, tiveram um efeito nocivo para os habitantes mais pobres da cidade, culminando num maior incremento de população na área de estudo, desprovida dos equipamentos públicos mínimos necessários a uma vida urbana digna.

Ao analisar o processo de metropolização de São Paulo, GROESTEIN (et al., 2001, p. 11) concluíram que "não houve, ao longo do século $X X$, nenhuma mudança que pudesse ser definida como uma ruptura do modelo, ou seja, uma reversão no processo espoliativo da urbanização metropolitana". Isso torna mais urgente a necessidade de repensar o modelo de cidade que estamos construindo e a questão do direito à cidade, edificado com base no diálogo das agendas urbana e ambiental, pois os problemas ambientais não serão resolvidos sem a solução dos problemas sociais. 
Passados trinta anos da publicação da obra A cidade invade as águas: qual é a questão das áreas de mananciais? (SÓCRATES et al., 1985), que pode ser considerado um marco em relação ao debate da questão do futuro e do que fazer em relação às áreas de mananciais da Região Metropolitana de São Paulo, ainda nos perguntamos quais são as perspectivas atuais para o entendimento dessas áreas. Esse livro é fruto de um enorme esforço de pesquisadores, de especialistas sobre o assunto e de diversos órgãos públicos, que apresentou todas as informações possíveis reunidas até 1985, num tempo em que se haviam passado dez anos da promulgação das Leis no 898/75 e no 1.172/76, que representavam, na época, a grande esperança de parte dos quadros técnico e político para a preservação e contenção da ocupação dessas áreas.

Nesse momento, procurava-se uma reflexão sobre quais haviam sido os "progressos" alcançados durante a década de vigência dessas leis, além da lei federal do parcelamento do solo, Lei Lehmann no 6.766/79, que também restringia o uso e a ocupação das áreas de proteção de mananciais, cujo parágrafo único e inciso $\mathrm{V}$ indicam, respectivamente, que:

\footnotetext{
Parágrafo único: Não será permitido o parcelamento do solo:

$\mathrm{V}$ - em áreas de preservação ecológica ou naquelas onde a poluição impeça condições sanitárias suportáveis, até a sua correção.
}

De acordo com MARTINS (2006, p. 57), um dos objetivos dessa lei era "a interdição de registro em cartório de propriedades em loteamentos irregulares", algo que na prática não se efetivou.

A área eleita para a realização desta pesquisa leva o nome de Península do Ribeirão Cocaia e localiza-se no extremo sul do munícipio de São Paulo, na Subprefeitura da Capela do Socorro, distrito do Grajaú, em um dos braços da represa Billings, denominado braço do Ribeirão Cocaia, que possui uma área de aproximadamente $19,29 \mathrm{~km}^{2}$. 
Figura 1. Região Metropolitana de São Paulo

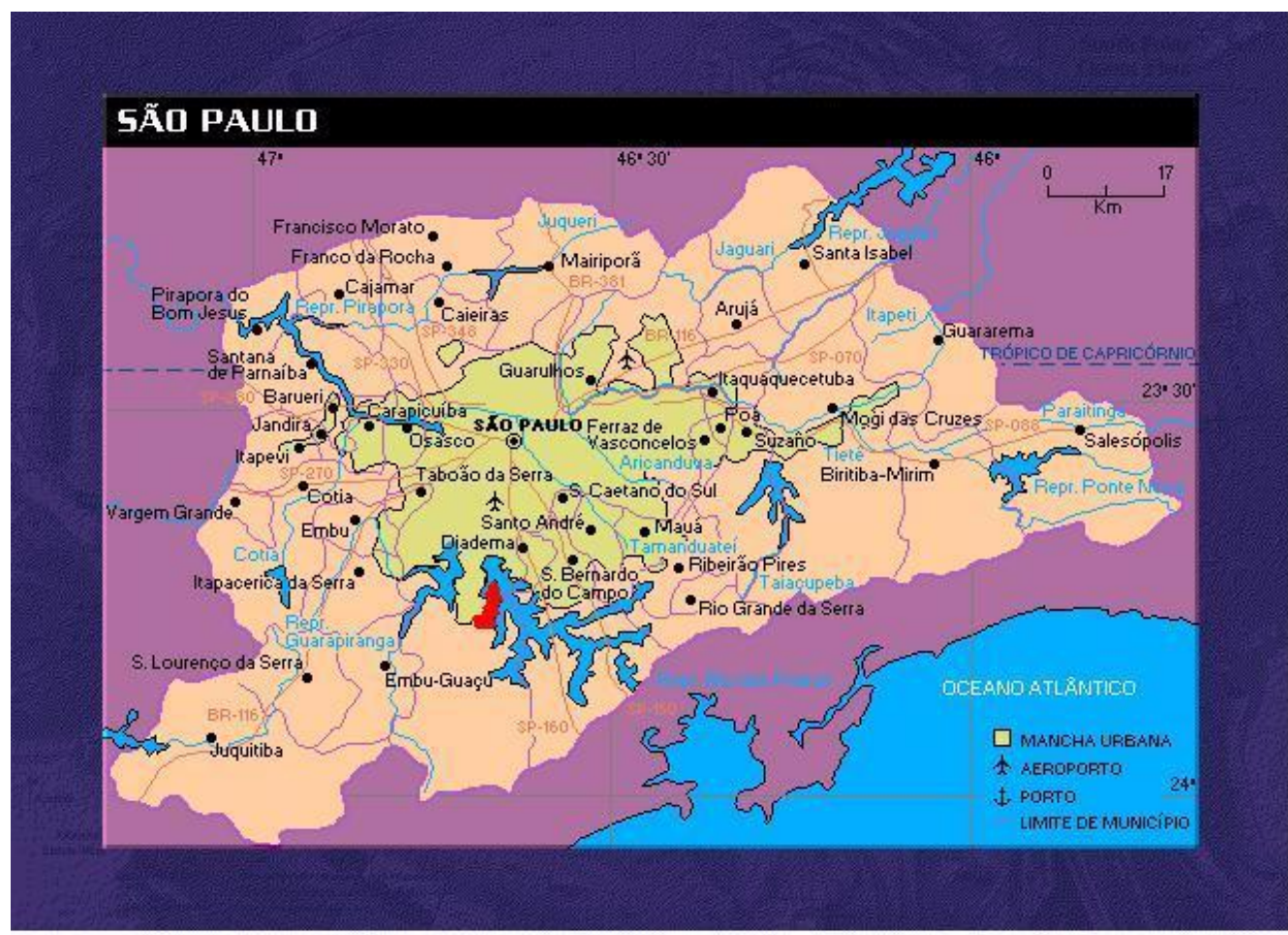

Fonte: Atlas geográfico ATR, 1994.

Figura 2. Divisão de subprefeituras do município de São Paulo

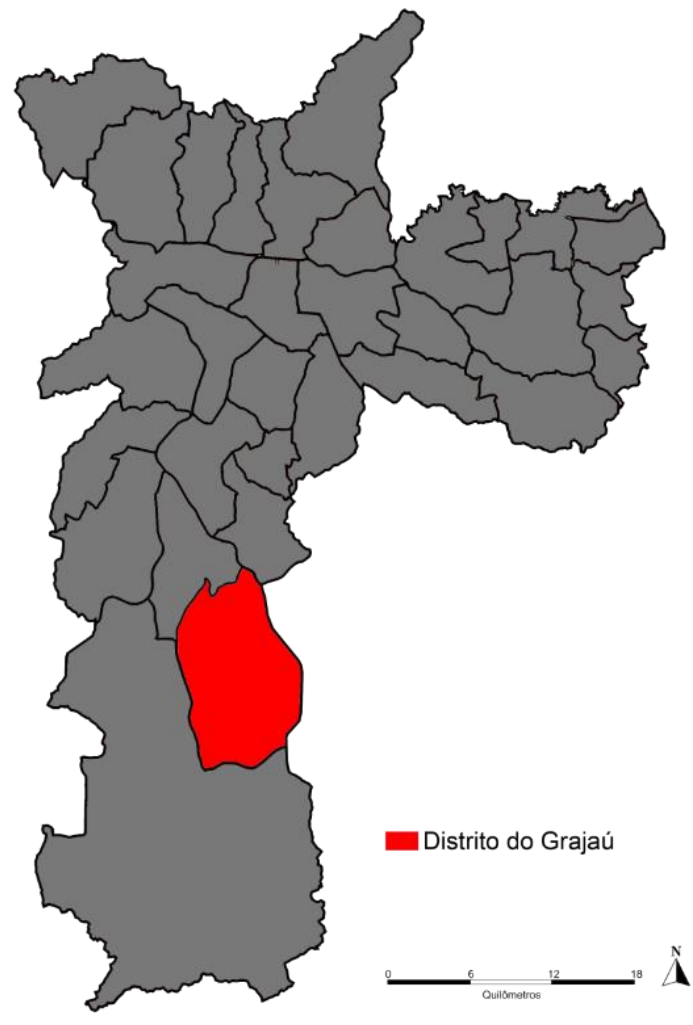

Fonte: Mapa base Sempla, 2014. 
O reservatório Billings, onde se localiza a sub-bacia do Ribeirão Cocaia, é resultante do barramento de diversos rios na região do bairro de Pedreira, localizado na Zona Sul do município de São Paulo.

A principal função desse reservatório era gerar energia elétrica para o sistema Henry Borden, localizado em Cubatão. Hoje, a represa encontra-se cercada pela mancha urbana que se expandiu em várias direções no município de São Paulo, especialmente para essa área do Ribeirão Cocaia.

Figura 3. Represa Billings, em São Paulo

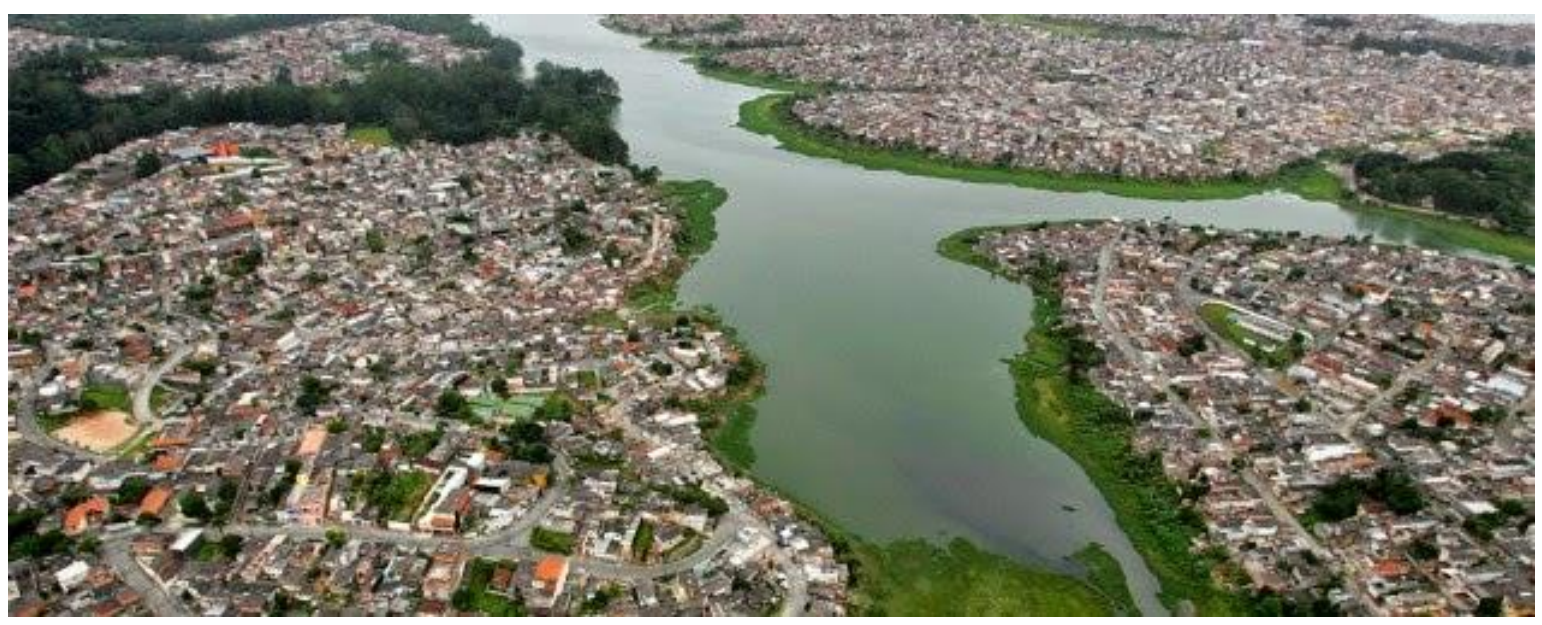

A Península do Ribeirão Cocaia abrange vários bairros, entre eles: Grajaú, Parque Residencial Cocaia, Parque Recanto Cocaia, Lago Azul e Cantinho do Céu, que apresentam um enorme adensamento populacional, conforme vemos na imagem acima.

Fonte: <amdro2003.blogspot.com.br>, 2014.

Atualmente, os dados mais recentes da Fundação Sistema Estadual de Análise de Dados (SEADE, 2014) mostram que o distrito do Grajaú conta com 372.467 habitantes, sendo o mais populoso da cidade. De qualquer forma, o problema não reside exatamente no adensamento populacional, mas onde a população está adensada e o motivo que a obrigou a instalar-se nesse local. 
Tabela 1. Aumento absoluto da população da Subprefeitura da Capela do Socorro em relação a São Paulo (1950-2010)

\begin{tabular}{|c|c|c|c|c|c|c|c|}
\hline \multirow{2}{*}{$\begin{array}{c}\text { Unidade } \\
\text { Territorial }\end{array}$} & \multicolumn{7}{|c|}{ População } \\
\cline { 2 - 8 } & $\mathbf{1 9 5 0}$ & $\mathbf{1 9 6 0}$ & $\mathbf{1 9 7 0}$ & $\mathbf{1 9 8 0}$ & $\mathbf{1 9 9 1}$ & $\mathbf{2 0 0 0}$ & $\mathbf{2 0 1 0}$ \\
\hline $\begin{array}{c}\text { Município de } \\
\text { São Paulo }\end{array}$ & 2.151 .313 & 3.667 .899 & 5.924 .615 & 8.493 .226 & 9.646 .185 & 10.434 .252 & 11.253 .503 \\
\hline $\begin{array}{c}\text { Capela do } \\
\text { Socorro }\end{array}$ & 6.583 & 19.347 & 103.793 & 281.029 & 405.769 & 563.922 & 594.930 \\
\hline $\begin{array}{c}\text { Cidade Dutra } \\
\text { Grajaú }\end{array}$ & $\mathbf{3 . 1 4 5}$ & 7.781 & 45.168 & 122.990 & 168.821 & 191.389 & 196.360 \\
\hline Gra & $\mathbf{8 . 9 8 9}$ & $\mathbf{4 3 . 6 6 4}$ & $\mathbf{1 1 7 . 3 0 1}$ & $\mathbf{1 9 3 . 7 5 4}$ & $\mathbf{3 3 3 . 4 3 6}$ & $\mathbf{3 6 0 . 7 8 7}$ \\
\hline
\end{tabular}

Fonte: IBGE. Censos demográficos. Organizado pelo autor.

O crescimento da cidade em direção às áreas de proteção de mananciais tem se tornado um grande problema ao longo de décadas. Apesar de haver uma legislação federal e municipal que regulamente o uso do solo, e de uma legislação específica estadual criada para a regulamentação da ocupação e proteção dessas áreas durante os anos 1970, o problema tem se agravado cada vez mais, ao passo que hoje se reconhece que a legislação não foi suficiente para diminuir - quanto mais frear - a ocupação dessas áreas. Vários autores, em diferentes momentos, evidenciaram essa falha:

As leis de proteção aos mananciais não conseguiram reverter o rápido e intenso crescimento populacional e urbano da RMSP, e o resultado contradiz seus objetivos: o território foi ocupado de forma mais adensada, irregular e precária, tendendo a uma população que não se encaixava nas alternativas de moradia oferecidas pelo mercado de terras formal. O poder público não soube gerir o crescimento urbano, não se preparou para fiscalizar intensamente de forma a evitar novas ocupações e, em último grau, considerando o grande número e área ocupada, não conseguiu intervir, provendo de saneamento e condições de boa habitabilidade, na mesma velocidade que se formava o quadro de degradação. (WHATELY et al. 2008, p. 42).

Para SÓCRATES et al. (1985, p. 29), "os problemas emergentes da ocupação das represas Billings e Guarapiranga têm demonstrado que a lei em si não foi capaz de conter completamente a ocupação dessas áreas". 
Nesse sentido, é de evidente importância a observação de VENTURI (2004, p. 248) de que "não se trata de incrementar o instrumental legal, mas de torná-lo viável a uma realidade que se impõe".

Conforme mencionado, ao observarmos o incremento recente da população no município de São Paulo, percebe-se que as taxas de crescimento vêm diminuindo (para algo em torno de 0,8\% ao ano), o que nos permite nos contrapormos às teorias mais conservadoras que indicavam que a cidade iria "explodir" em decorrência de seu enorme crescimento populacional. Em contrapartida, porém, o crescimento na área de estudo elevou-se a taxas acima de $6 \%$ ao ano durante os anos 1990, e ainda hoje é um pouco superior à média da cidade de São Paulo.

Tabela 2. Relação das taxas de crescimento populacional entre o Município de São Paulo e o Subdistrito de Grajaú (1960-2010)

\begin{tabular}{|c|c|c|c|c|c|c|}
\hline Ano & $\mathbf{1 9 6 0}$ & $\mathbf{1 9 7 0}$ & $\mathbf{1 9 8 0}$ & $\mathbf{1 9 9 1}$ & $\mathbf{2 0 0 0}$ & $\mathbf{2 0 1 0}$ \\
\hline Município de São Paulo & $5,48 \%$ & $4,91 \%$ & $3,67 \%$ & $1,16 \%$ & $0,88 \%$ & $0,76 \%$ \\
\hline Bairro Grajaú & $9,16 \%$ & $17,12 \%$ & $10,39 \%$ & $4,67 \%$ & $6,22 \%$ & $0,79 \%$ \\
\hline
\end{tabular}

Fonte: Fundação Seade, 2015.

Esses dados nos dão condições para estabelecer as primeiras aproximações sobre o entendimento da urbanização na Península do Ribeirão Cocaia e nos fazem intuir que o problema não é mais exatamente o do crescimento da cidade de São Paulo, mas definir exatamente "onde" ela cresce de forma mais acelerada e o "porquê" desse crescimento.

Certamente parte da solução dos problemas das áreas de proteção aos mananciais está em buscar respostas, e não em criminalizar a população que reside nesses locais, como tem sido feito ao longo de décadas. Enquanto se discutiam as leis - se seriam flexibilizadas ou não - em função das ocupações, a cidade crescia, se fazia e refazia, também dentro das áreas de preservação. 
Em um momento em que se discute a crise da água como se fosse um problema recente, a mídia, em geral, acaba por não abordar as reais causas da escassez hídrica, e suas matérias não têm caráter propositivo, no sentido de fornecerem subsídios ao debate ou encaminhamentos para resolver o problema da falta de água na cidade de São Paulo.

Os meios de comunicação, na verdade, acabam por criar um clima de forte oposição entre as pessoas que não moram em áreas de mananciais e a população que reside nesses locais, criminalizando as práticas desta última, em vez de discutir o problema ligando-o ao modelo de cidade que se foi construindo ao longo do tempo: uma cidade excludente que praticamente exilou boa parte da população mais pobre para regiões muito distantes, fazendo com que fossem morar em áreas impróprias, com grande fragilidade ambiental, como é o casa das áreas de mananciais.

SILVA (2001) mostra, por meio de um modelo tridimensional de terreno, construído com mais de 850 pontos de altitude cotados, a área de estudo possuidora de um relevo bastante movimentado e próxima do reservatório, o que dificulta sua ocupação por causa de questões relacionadas à alta declividade, à salubridade e ao risco de inundação por existirem lugares muito próximos quando não dentro da própria borda do reservatório.

Figura 4. Modelo tridimensional da Península do Ribeirão Cocaia, Parque Residencial Cocaia, Parque Recanto Cocaia, Grajaú, Cantinho do Céu e adjacências

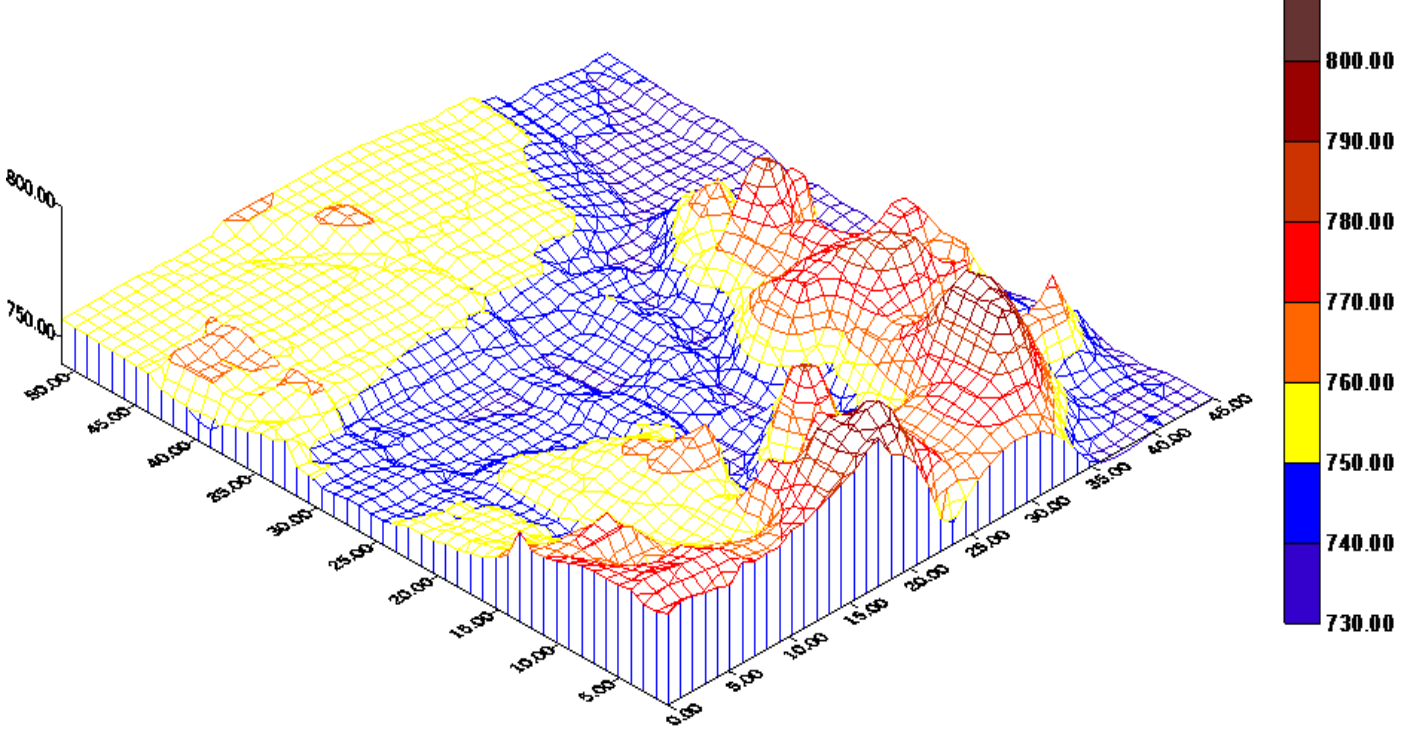

Fonte: Silva (2001, p. 66). 
O que se tem notado é que parece que não se quer resolver o problema, mas apenas evitar um colapso do capital, pois, pela primeira vez, a questão da água em São Paulo coloca em risco as condições para realizar a acumulação de capital. Como enfatiza Harvey:

O direito a cidade está, por isso, além de um acesso àquilo que já existe: é um desejo de mudar a cidade mais de acordo com o nosso desejo íntimo. A liberdade para nos refazermos, assim como as nossas cidades, é um dos mais preciosos, ainda que dos mais negligenciados, dos nossos direitos humanos. (HARVEY, 2009, p. 9).

\section{Objetivos da pesquisa e pressupostos teórico-metodológicos}

Na metrópole corporativa paulistana, a quantidade de água é a mesma e a população aumenta, principalmente, nas áreas de preservação ambiental. Em face do problema da ocupação da área de mananciais que põe em risco a qualidade das águas superficiais da RMSP e do perigo de sua escassez, esse trabalho servirá para entender as principais características da gênese da ocupação e os problemas socioambientais mais significativos da área estudada.

A pesquisa tem também o objetivo de discutir a lógica de ocupação da Península do Ribeirão Cocaia, que compreende os bairros do Grajaú, Parque Recanto Cocaia, Parque Residência Cocaia, Jardim Gaivotas e Cantinho do Céu, sendo necessário para isso identificar e compreender as principais determinações do processo de expansão da mancha urbana, que levou à ocupação das áreas de proteção aos mananciais no munícipio de São Paulo.

Desse modo, não se trata de fazer apenas uma história do espaço recorrendo a todos os eventos da urbanização de São Paulo, mas, sim, de focar especialmente nessa área localizada no extremo da Zona Sul da cidade de São Paulo, investigando os principais processos que levaram à urbanização precária dessa área, com o intuito de identificar os processos fundamentais que levaram àquela configuração metropolitana, assim como definir quais os agentes sociais envolvidos mais importantes, como donos de terra, Estado, população e movimentos sociais que atuam na área da pesquisa. 
Com relação ao método, um dos principais pressupostos que assumimos é o de que o espaço é uma instância social, pois, segundo Villaça:

\begin{abstract}
Provavelmente o maior avanço ocorrido no campo da ciência da geografia em todos os tempos tenha sido a consciência e a recente difusão da ideia (Lefèbvre, Harvey, Gottdiener e tantos outros) de que o espaço social no nosso caso, o espaço urbano - é socialmente produzido, ou seja, não é dado pela natureza, mas é produto produzido pelo trabalho humano. (VILLAÇA, 2011, p. 37).
\end{abstract}

Portanto, concordando com CARLOS (2007, p. 51), não consideramos o espaço como palco, como algo inerte, mas como "movimento e processo realizando-se na tríade condição, meio e produto da produção/reprodução da sociedade".

Ademais, SANTOS (2004) concebe o espaço como um "processo indissociável de sistema de objetos e ações" que é gerado pela sociedade e ao mesmo tempo produz esta sociedade numa relação dialética.

Ao estudarmos a produção do espaço no subdistrito do Grajaú, que atualmente encontra-se inserida na área de proteção aos mananciais, isso fica bem evidente na medida em que, após a instalação da Cohab Faria Lima (1973-1975), muda significativamente a produção do espaço da área de estudo.

Assim, definindo o espaço como um sistema indissociável de objetos e ações em conjunto, podemos pensar os espaços contidos na metrópole com o que Milton Santos (1998) designou de Espaços Luminosos e Espaços Opacos.

A produção específica deste espaço, principalmente nos anos 1980 e intensificada a partir do auge do neoliberalismo na América Latina durante os anos 1990, criou cada vez mais marcas na cidade como uma cidade fragmentada e polarizada, com áreas muito abastadas e outras de grande precariedade.

O conceito de espoliação urbana, tratado por Kowarick (2009), ao retomar em seus Escritos urbanos as ideias desenvolvidas no livro $A$ espoliação urbana, de 1979, convida-nos a repensar esse conceito, pois, para esse autor, o termo significa: 
A somatória de extorsões que se opera pela inexistência ou precariedade de serviços de consumo coletivo, que, juntamente com o acesso à terra e à moradia, apresentam-se como socialmente necessários para a reprodução dos trabalhadores e aguçam ainda mais a dilapidação decorrente da exploração do trabalho, ou, o que é pior, da falta deste. (KOWARICK, 2000, p. 22).

Esse conceito é muito pertinente para ajudar a explicar o contexto da área de estudo formada em grande parte pela expropriação da classe trabalhadora. Porém, essa população, além de pauperizada, também está, em grande parte, em um sítio urbano extremamente desfavorável, ou seja, em uma área que apresenta grande fragilidade ambiental, seja por riscos de contaminação pela água, riscos de enchentes e de deslizamento. Por isso, consideramos muito importante acrescentar a dimensão ambiental ao problema da espoliação urbana.

Conforme mostra a legislação, os direitos ao urbano dizem respeito ao ambiente físico, como está escrito na Constituição brasileira que declara em seu Caput que:

Art. 225. Todos têm direito ao meio ambiente ecologicamente equilibrado, bem de uso comum do povo e essencial à sadia qualidade de vida, impondo-se ao Poder Público e à coletividade o dever de defendê-lo e preservá-lo para as presentes e futuras gerações.

Vários são os estudos (ALVES, 2006; MARTINS, 2007) que têm demonstrado uma relação extremamente perversa, e não casual, da localização da população mais pobre às áreas que elas ocupam na cidade como as áreas de maior de fragilidade ambiental. Nesse sentido, assumimos o conceito de vulnerabilidade socioambiental proposto por Alves em que ele define como:

A coexistência ou sobreposição espacial entre grupos sociais muito pobres e com alta privação (vulnerabilidade social), em áreas de risco ou de degradação ambiental (vulnerabilidade ambiental). Neste sentido estamos considerando que é justamente a combinação destas duas dimensões que caracteriza uma situação de vulnerabilidade socioambiental. (ALVES, 2006, p. 44). 
Não é por acaso que os mais pobres estão morando nas piores áreas do ponto de vista urbano-ambiental nas grandes cidades brasileiras. Isso se deve ao fato de que São Paulo foi estruturada, em grande parte, para a realização da maisvalia, banindo os pobres das áreas mais valorizadas da cidade e os jogando nas áreas de maior fragilidade ambiental. Esse problema deve-se também a um Estado patrimonialista, que defende a propriedade privada em detrimento da função social da propriedade. Por isso sua ação na área de estudo é importante objeto de análise para compreender a situação atual. 


\section{Capítulo 1: Crescimento da cidade de São Paulo e expansão para a Zona Sul}

\subsection{0 crescimento da cidade de São Paulo: breve histórico}

A cidade de São Paulo, nos seus três primeiros séculos até 1870, era muito pequena. Segundo BARBOSA (1987, p. 267), "o raio do círculo que continha a área construída não ultrapassava de 1 km".

O crescimento da cidade de São Paulo ocorreu somente a partir do final do século XIX, quando os capitais oriundos da economia cafeeira precipitaram um rápido crescimento populacional da cidade, conforme mostra a tabela abaixo.

Tabela 3. População da cidade de São Paulo

\begin{tabular}{|c|c|c|}
\hline Anos & População & $\begin{array}{c}\text { Taxa de crescimento } \\
\text { ( \%) }\end{array}$ \\
\hline 1872 & 31.385 & 4,1 \\
\hline 1890 & 64.934 & 14,0 \\
\hline 1900 & 289.820 & \\
\hline
\end{tabular}

Fonte: <http://smdu.prefeitura.sp.gov.br/historico_demografico/tabelas.php>. Acesso em: fev. 2016.

Em um intervalo de apenas dezoito anos a população cresceu nove vezes, tornando-se o primeiro grande crescimento populacional da história da cidade de São Paulo.

Até a década de 1870, com exceção das chácaras periféricas, quase não havia diferenças funcionais de um ponto a outro da cidade. As residências dos mais abastados e da classe alta muitas vezes localizavam-se no próprio "triângulo" central, junto ao comércio e às oficinas. (MATOS :1958, p. 58).

A partir de 1880 começa, ainda que lento, o processo de segregação socioespacial, com o surgimento de bairros residenciais ricos para elite, como Campos Elísios, e bairros operários, como Santa Efigênia e Brás, ainda relativamente próximos ao centro. 
Figura 5. Palácio dos Campos Elíseos

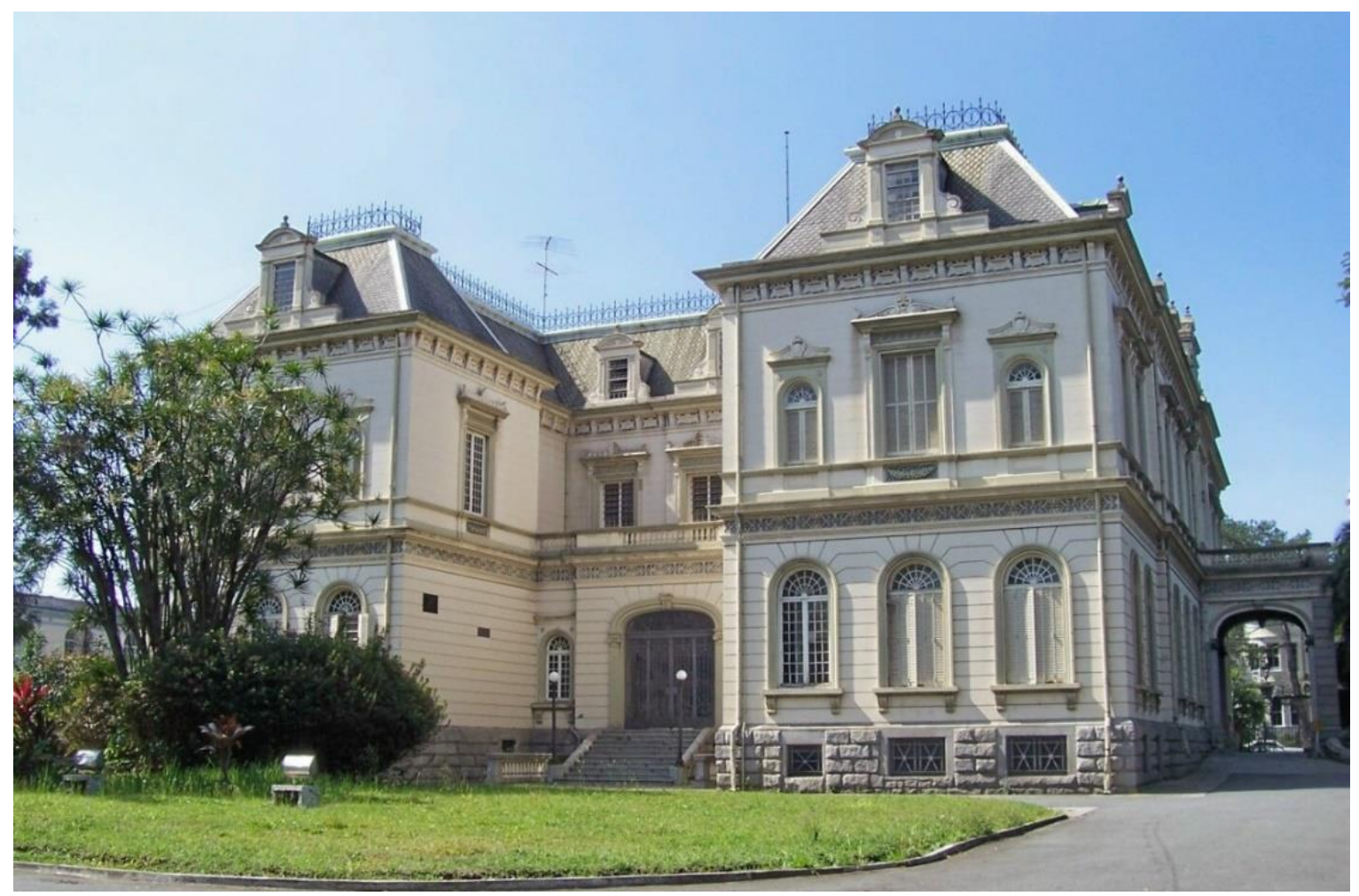

Palácio dos Campos Elíseos, no bairro de Campos Elíseos, em São Paulo, SP. Edifício do século XIX foi também sede do governo de São Paulo. Foto: Regina Kalmann, 3 de setembro de 2006.

Figura 6. Brás: antiga Ladeira do Carmo (atual Rangel Pestana)

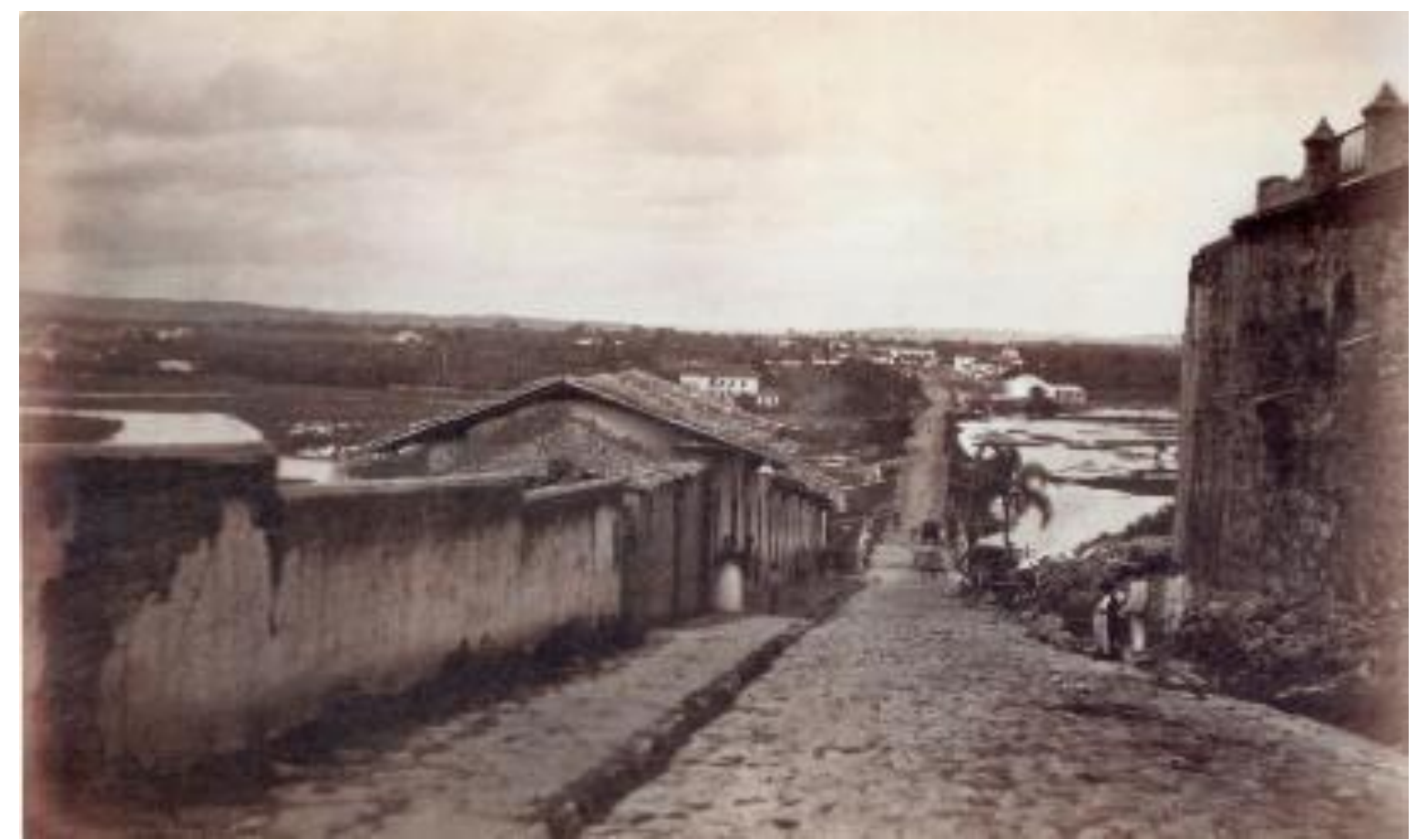

$\mathrm{Na}$ foto ainda se pode observar, ao fundo, o rio Tamanduateí num período de cheia. Foto de Militão Augusto de Azevedo, 1862. Acervo PMSP/SMC/DPH/DIM. 
A solução para a população de baixa renda, nesse período, foram as vilas operárias construídas por alguns empresários, das quais a mais famosa foi a Vila Maria Zélia, descrita amplamente na literatura. Entretanto, como elas eram em pequeno número, não foram suficientes para abarcar toda a demanda do período, e a população trabalhadora viu-se obrigada a encontrar uma alternativa viável para o problema habitacional da época, que foi a dos cortiços, a única possibilidade de moradia encontrada em uma cidade em plena expansão.

Paralelamente a esse processo inicial de crescimento, a cidade de São Paulo começa a exercer influência em cidades vizinhas, entre elas Santo Amaro.

Santo Amaro surgiu de um aldeamento indígena, que era chefiado por Caiubi, um dos dois chefes da tribo dos índios guaianases, juntamente com Tibiriçá. Segundo PONCIANO (2001): "Em 12 de agosto de 1560, os padres jesuítas tomaram posse oficial de duas léguas de terras junto à margem esquerda do rio Jeribatiba ou Jurubatuba, que em tupi significa 'muitos jerivás' - um tipo de palmeira de porte médio comum na região e que chegou a identificar o rio". Sobre isso, BERARDI (1984) fala que "as terras foram doadas aos jesuítas pelo Capitão Francisco de Morais, em nome do padre Luís da Grã Província da Companhia de Jesus, em 26 de maio do mesmo ano".

Essas aldeias haviam sido atingidas pelos jesuítas graças aos "rios da bacia do Tietê, que eram utilizados como meio de transporte e comunicação dos jesuítas em suas peregrinações de missionários pelas aldeias indígenas disseminadas pelos arredores, a uma, duas e três léguas por água, e que os padres iam se estabelecendo à margem dos rios sempre que possível". (BERARDI, 1984).

Anteriormente à colonização portuguesa, a região era conhecida como "Campo do Ibirapuera" ou "Virapuera" (que vem do tupi ybi-ra-qüera e significa "madeira podre" ou "árvore velha"). O bairro recebeu ao longo dos séculos nomes como Virapuera, Jeribatiba, Ibirapeuera, Santo Amaro de Virapeuera e, finalmente, Santo Amaro. PONCIANO (2001, p. 182). 
O nome Santo Amaro deve-se à doação que o casal João Paes e Suzana Rodrigues fez de uma pequena imagem de madeira do Santo com o mesmo nome para uma pequena capelinha erguida no novo núcleo recém-criado. Santo Amaro é conhecido como o padroeiro dos agricultores e dos carroceiros.

Era uma região de relevo brando, com lindas e extensas campinas. $O$ morro da barra, no fim de uma cadeia de colinas, estava bem na confluência dos rios Jurubatuba (ou Geraibatiba) e Guarapiranga. Nas várzeas desses dois rios havia matas cerradas, que em alguns pontos mais afastados tomavam aspecto de sertão bravio. (BERARDI, 1984).

Figura 7. Ponte sobre o rio Grande, em Santo Amaro

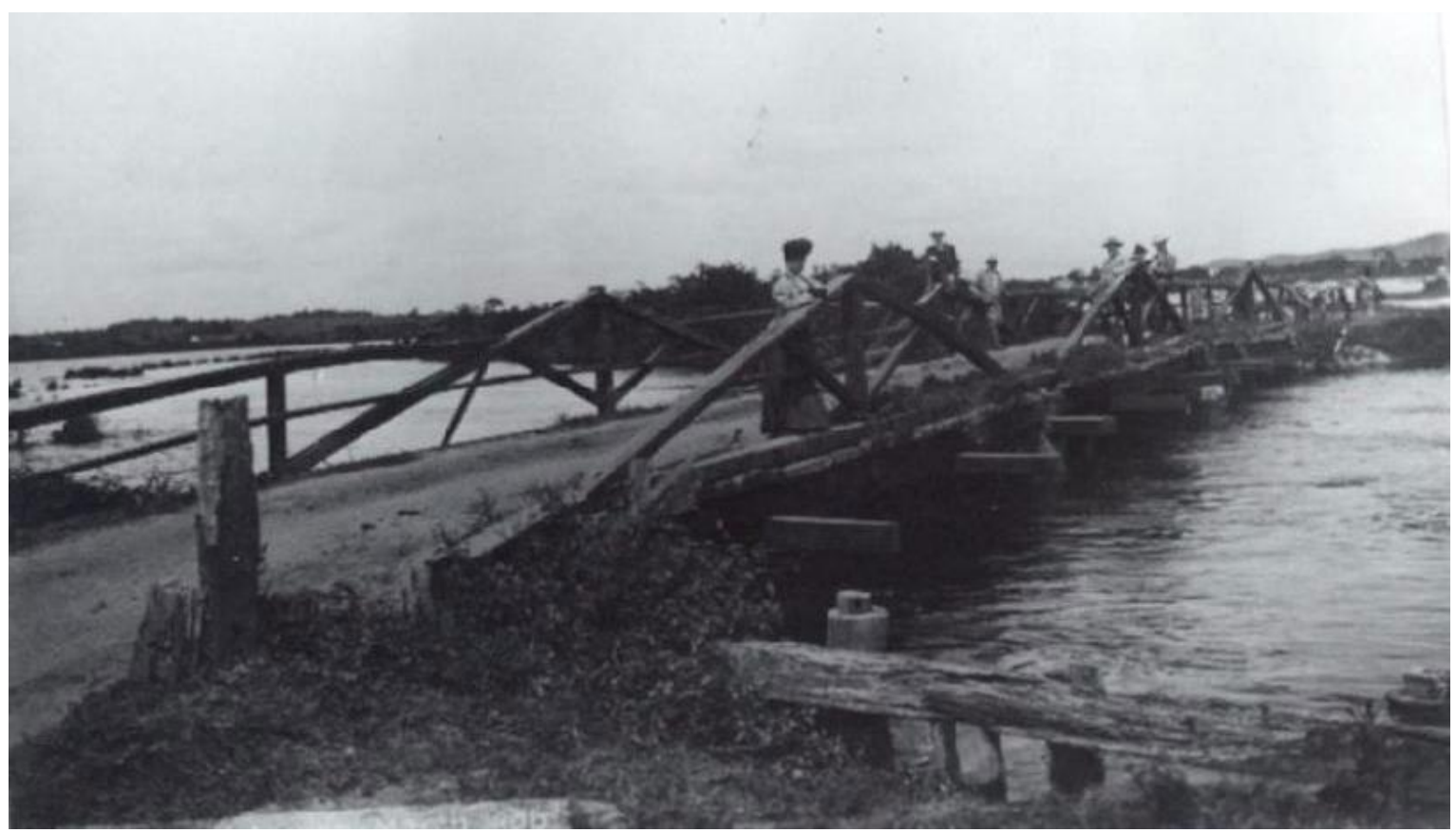

A foto de 1906 mostra boa parte das características da área descritas por Berardi.

Santo Amaro, que havia se constituído de um antigo núcleo de colonização jesuíta, torna-se munícipio em 10 de julho de 1832. Um decreto da Regência transformou em vila várias freguesias da Província de São Paulo, entre elas Santo Amaro. Na época, não havia registro de movimentos separatistas de grande consistência em Santo Amaro. O que se dava era um descontentamento nacional e regional devido ao centralismo exacerbado do imperador do Brasil Dom Pedro I, que, entre outros fatores, o conduziu à renúncia. O país passou então para um 
regime de regência trina permanente, em que um dos regentes foi o ministro Padre Feijó, do Partido Liberal, que estava sendo pressionado por várias câmaras para conceder mais autonomia a diversas províncias e a emancipação a outras. Nesse bojo, Santo Amaro consegue sua autonomia. Tal fato torna-se evidente com os relatos da época.

A notícia de que Santo Amaro agora era um município foi recebida com $T e$ Deum, música e luminárias... Padre Antônio Benedito dava graças a Deus pelo progresso da terra. Não havia sede da municipalidade, porém o padre Benedito cedeu um cômodo da matriz para que ali se fizessem as reuniões até a construção de uma casa de câmara. (BERARDI, 1984).

Cabe lembrar que até então São Paulo era uma cidade muito modesta, limitada praticamente na sua colina histórica e as suas relações com as cidades vizinhas eram à época muito acanhadas. Todavia, a partir das últimas três décadas do século XIX, São Paulo passa por grandes transformações e isso vai se refletir diretamente no papel e na configuração espacial das cidades ao redor, especialmente de Santo Amaro.

No final do século XIX, Santo Amaro passa a participar do processo do crescimento de São Paulo, de maneira complementar como fornecedor de matérias, e fica conhecido nesse período como celeiro da capital. Segundo LAGENBUCH (1971, p. 198), "Santo Amaro respondia por 100\% da produção de batatas e de marmelada de toda a província de São Paulo, destacando-se ainda no fornecimento de itens como: milho, farinha de mandioca, carne, madeira, areia e pedras de cantaria".

Devido à importância da produção de gêneros alimentícios para abastecer a população da cidade de São Paulo, é construído em 1895 o Mercado Municipal de Santo Amaro. 
Figura 8. Antigo Mercado Municipal de Santo Amaro

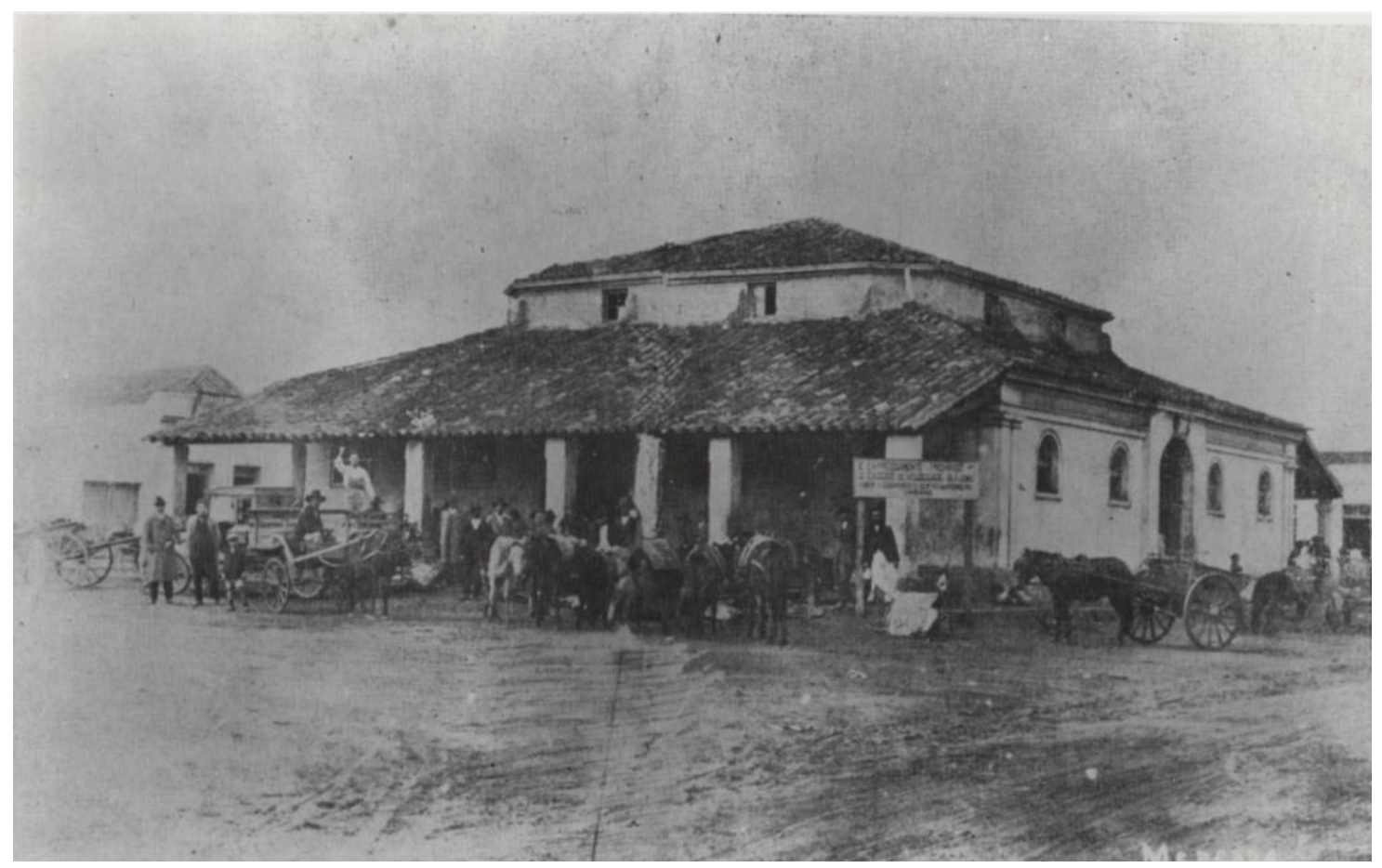

Antigo Mercado Municipal de Santo Amaro, 1900. Foto do Arquivo Municipal da Prefeitura Municipal de São Paulo.

Em 14 de março de 1886 é inaugurada a via férrea Ferro Carrilis. Segundo OLIVEIRA (1996, p. 53): "A estrada de ferro que ligava São Paulo a Santo Amaro, internalizando neste último, uma nova tecnologia, a do vapor, tinha no matadouro e no abastecimento da Capital uma de suas razões principais".

Entre 1886 e 1900, a companhia Carris de Ferro de São Paulo S. A. monopolizou o fluxo das principais produções de Santo Amaro, a carne e a madeira, sofrendo apenas a concorrência dos carros de boi, que sob certas circunstâncias Ihes eram complementares.

Além de ser considerado como o celeiro da capital entre o final do século XIX e o início do século XX, Santo Amaro teve outro relevante papel que foi desempenhado a partir da construção de dois imensos lagos artificiais durante as primeiras décadas do século XX. Trata-se da represa Guarapiranga e do reservatório Billings, que ocupam grande área do antigo município de Santo Amaro, hoje Zona Sul da cidade de São Paulo. Com o desenvolvimento desses sistemas técnicos, a represa Guarapiranga (1906-1909) e Billings (1925-1927), Santo Amaro passa a ser extremante importante, fornecendo água e energia elétrica para o 
desenvolvimento de São Paulo, que viria a se constituir como metrópole a partir da década de 1950. Dada a importância estratégica para o crescimento da cidade de São Paulo, Santo Amaro foi anexada à capital paulista em 22 de fevereiro de 1935.

\subsection{A metrópole corporativa e a periferização da cidade}

SANTOS (1990, p. 94) discute a formação da metrópole corporativa, o que significa uma cidade e seu espaço estruturados "muito mais preocupados com a eliminação das deseconomias urbanas do que com a produção de serviços sociais e com o bem-estar coletivo". Uma metrópole que foi totalmente estruturada para a facilitação dos fluxos e acumulação e produção de riquezas para as empresas, especialmente para as multinacionais que vieram definitivamente para o Brasil a partir de meados dos anos 1950, com toda a força durante o governo de Juscelino Kubitschek. Para Santos:

\footnotetext{
$\mathrm{Na}$ cidade corporativa, o essencial do esforço de equipamento é primordialmente feito para serviço das empresas hegemônicas; o que porventura interessa às demais empresas e a grosso da população é praticamente residual na elaboração dos orçamentos públicos. Isso obedece à mais estrita racionalidade capitalista, em nome do produto nacional, da capacidade de exportação, etc. (SANTOS, 1990, p. 95).
}

Dessa forma, a cidade é produzida não para os cidadãos, mas para satisfazer às necessidades das grandes empresas, principalmente as multinacionais, e os investimentos nas áreas sociais não passam de um parco detalhe. E quando são feitos, muitas vezes acabam mais por agravar a situação dos mais pobres do que realmente resolver o problema, conforme veremos no caso do Banco Nacional de Habitação (BNH), apresentado como proposta de solução habitacional adotada durante o Regime Militar (1964-1986).

Assim sendo, a instalação de uma série de objetos técnicos como estradas, portos, aeroportos, construções de grandes parques industriais, represas, grandes conjuntos habitacionais em áreas precárias vieram corroborar para estruturar essa metrópole. 
Santo Amaro, em virtude das transformações apresentadas pela metrópole paulista, mais uma vez também modificará sua função, que vinha se desenhando até a década de 1940, que era de subúrbio residencial, e passara, paulatinamente, a partir dos anos 1950, a apresentar a característica de periferia industrial de São Paulo, principalmente após o espraiamento urbano do município de São Paulo, ocorrido entre as décadas de 1940 e 1970.

Diversos são os fatores responsáveis pelo grande espraiamento da cidade de São Paulo a partir dos anos 1940. E entre os principais fatores estão a construção e modernização de grandes avenidas e a opção pelo modelo rodoviário como modelo prioritário de transportes; a instalação maciça das multinacionais a partir dos anos 1950; a instituição de normas ligadas ao urbanismo e à questão habitacional brasileira da época que vão rebater no espaço e direcionar o crescimento para áreas de fragilidade ambiental, para onde a cidade não deveria crescer, entre outros.

É de grande importância a força das normas como articuladoras/desarticuladoras do espaço social e mais precisamente do espaço urbano metropolitano. Silveira propõe o conceito de concretude territorial como um:

Processo de construção de um meio perfeito, povoado de híbridos, na forma de objetos, ações e normas, e que é simultâneo a outras instâncias da sociedade. A concretude territorial resulta ao mesmo tempo da convergência entre funções planejadas e as funções desenvolvidas nos lugares. (SILVEIRA, 1997, p. 43).

A mesma autora (1997, p. 36) ressalta que "algumas normas antecedem a modernização material". Então, devemos ficar atentos ao efeito de suas aplicações sobre as diferentes porções do espaço, aos lugares onde são aplicadas. Antes de falar propriamente das áreas de proteção de mananciais na cidade de São Paulo e das normas propriamente ditas, que são exclusivas de aplicação nessas áreas, cabe interrogar: por que essas áreas cresceram e foram ocupadas? E, para responder a essa questão, faz-se necessária uma breve reflexão sobre os motivos do crescimento da cidade de São Paulo. Para compreender esse processo, passaremos a analisar brevemente duas normas e as suas consequências socioespaciais que levaram ao espraiamento da cidade de São Paulo. 
A lei do inquilinato, de 1942, é um fator pouco relacionado à questão do crescimento da ocupação de áreas de proteção aos mananciais, mas que pode se constituir como um embrião do que viria a acontecer, no Brasil e especialmente na cidade de São Paulo.

Essa lei tinha a função de regulamentar os alugueis e para isso os congelava. Isso aparentemente favorecia os trabalhadores, mas acabou por desestimular a construção de moradias para locação e fez com que existisse uma grande crise por habitação especialmente na cidade de São Paulo, sendo que:

A regulamentação do mercado de aluguéis a partir de 1942, ano em que os aluguéis foram congelados, constitui uma das principais causas da transformação das formas de provisão habitacional no Brasil e em São Paulo, desestimulando a produção rentista e transferindo para o Estado e para os próprios trabalhadores o encargo de produzir moradias. (BONDUKI, 2004, p. 209).

Um fato muito relevante que se deve levar em consideração são os efeitos econômicos e socioespaciais causados por essa lei. Se analisarmos os dados da década de 1920 na cidade de São Paulo, cerca de 79\% dos domicílios eram ocupados por locatários, e 19\% por proprietários. Já no início da década de 1940, o número de locatários havia tido uma queda para $67 \%$, enquanto o de proprietários havia aumentado também para $25 \%$, aumento de apenas $8 \%$ em vinte anos. Mas, após a aplicação da lei entre os anos de 1950 e 1970, acontece a grande inversão desses números, pois em 1950 o número de locatários já era de 58\% e passa em 1970 para 38\%. Já o número de proprietários que era de 37\% em 1950 passa para $54 \%$ em 1970, tendência que se matém até hoje. 
Tabela 4. Distribuição dos domicílios segundo o tipo de ocupação na cidade de São Paulo (1920-2010)

\begin{tabular}{|l|c|c|c|c|c|c|c|}
\hline Condição de ocupação & 1920 & 1940 & 1950 & 1970 & 1991 & 2000 & 2010 \\
\hline $\begin{array}{l}\text { Ocupados por locatários } \\
79 \%\end{array}$ & $67 \%$ & $58 \%$ & $38 \%$ & $28,75 \%$ & $21,6 \%$ & $25,25 \%$ \\
\hline $\begin{array}{l}\text { Ocupados por } \\
\text { proprietários }\end{array}$ & $19 \%$ & $25 \%$ & $37 \%$ & $54 \%$ & $63,57 \%$ & $63,57 \%$ & $70,41 \%$ \\
\hline
\end{tabular}

Fonte: IBGE. Organizado pelo autor.

Segundo os dados mais recentes do IBGE Censo 2010, a cidade de São Paulo contava com 3.573.509 de domicílios no total, desses 2.221.257 são próprios e 831.181 alugados, o que perfazem um percentual de $62,1 \%$ dos domicílios próprios na cidade, enquanto o percentual de domicílios alugados é de apenas $6,5 \%$.

Optou-se por não colocar outros tipos de ocupação, já que o foco principal são as moradias alugadas ou próprias. Mas quais foram as consequências do ponto de vista da economia e do ponto de vista espacial desta lei? Do ponto de vista da economia poderíamos destacar que houve um desestímulo da produção habitacional rentista, através da:

Queda acentuada da rentabilidade na locação imobiliária devido a controles institucionais e grande incentivo de aplicação de capital em atividades industriais. [...] além de ser um incentivo para reduzir o custo de reprodução da força de trabalho. (BONDUKI, 2004, p. 244-245).

O resultado desse processo na década de 1970 é o da constatação que Francisco de Oliveira fez na época ao realizar uma pesquisa sobre habitação popular nas cidades de Cubatão e Santos, sendo que a maior parte das habitações era própria. Nas palavras do autor:

[...] alguma coisa está errada. Isso não é um país socialista, então deve ter alguma coisa errada [...] eu diria que a industrialização brasileira foi sustentada por duas fortes vertentes. A primeira foi a vertente estatal, pela qual o Estado transferia renda de certos setores e subsidiava a implantação industrial. E a segunda eram os recursos da própria classe 
trabalhadora, em que autoconstruía sua habitação e com isso rebaixava o custo de reprodução [...]. Quando os governos, para orientar a política econômica, calculam o salário mínimo, o custo da habitação desaparece e influencia na fixação do valor. É isso que tem o efeito de rebaixar o salário. O círculo se fechava. O capital se reproduz com o rebaixamento do custo da força de trabalho ou, em outras palavras, com o rebaixamento do salário. Desse ponto de vista, a autoconstrução era estranhamente um mecanismo de acumulação primitiva, pois a casa construída daquela forma não se transformava em capital. (OLIVEIRA, 2006, p. 68).

Mais do que a solução para os problemas da classe trabalhadora, a lei do inquilinato foi uma maneira encontrada para resolver a questão da industrialização do capitalismo brasileiro. Esse fato teve enormes consequências socioespaciais para as cidades brasileiras. No caso de São Paulo, a cidade se espraia, pois não havia oferta de moradias para locação a baixos preços em áreas centrais ou próximas ao centro fazendo com que a população começasse a ocupar as áreas cada vez mais distantes. É o início da formação das periferias paulistanas.

Esse processo ocorre concomitantemente a novas normas na legislação urbana como, a Lei no 5.261, de 1957, sancionada pelo prefeito Adhemar de Barros, que tinha uma postura favorável ao espraiamento da cidade, inspirado nos modelos de subúrbios norte-americanos. Essa lei propõe que não poderiam ser construídos prédios com áreas que fossem quatro vezes maiores que a do terreno. Isso fez com que áreas centrais que poderiam alocar mais moradores acabassem sendo subutilizadas, fato que contribuiu ainda mais para acentuar o mecanismo de espraiamento da cidade.

\subsubsection{Mudança no modelo de transporte}

A mudança do modelo de transporte também foi decisiva para o espraiamento urbano, na medida em que a cidade era servida pelas linhas de bondes. Era difícil que ela crescesse muito, pois o custo de levar o transporte até os trabalhadores era muito alto, inviabilizando a dispersão espacial para áreas muito distantes do centro da cidade como conhecemos hoje. Mas, por meio do prefeito Prestes Maia, aos poucos esse problema foi sendo resolvido, já que ele é precursor das avenidas de fundo de vale, como a Nove de Julho, e a Vinte e Três de Maio, que mais tarde resultariam em problemas dos quais hoje somos tributários como grandes 
enchentes, que as cidades vivem principalmente nos períodos do verão devido ao sufocamento dos rios.

Com a abertura das avenidas de fundo de vale e a renúncia ao investimento de obras como as do metrô - isso do ponto de vista mais específico da cidade, juntamente com a chegada das grandes montadoras ao país -, o espaço urbano torna-se um caminho amplo para a implantação definitiva do modelo viário do automóvel e para a implementação urbana do novo modelo de transporte de massa sobre pneus, o ônibus "um sistema de baixa densidade e alta capilaridade" Bonduki (2004, p. 285). Esse modelo de transporte foi um dos fatores decisivos para a formação da enorme periferia paulistana. Ele contribuiu muito para reforçar o processo de especulação imobiliária, uma vez que poderia atender às pessoas em áreas cada vez mais distantes, permitindo que grandes glebas de terra ficassem apenas à espera de melhor oportunidade para a valorização, favorecendo os vazios nas cidades, acentuando, assim, a especulação imobiliária, com isso a cidade começa a alcançar as áreas das represas Billings e Guarapiranga, que haviam sido construídas nas primeiras décadas do século XX.

\subsubsection{A construção dos reservatórios Guarapiranga e Billings}

Os reservatórios Guarapiranga e Billings foram construídos nas primeiras décadas do século $\mathrm{XX}$, com uma característica espacial muito interessante, pois ambos se localizam, em grande parte, no antigo munícipio de Santo Amaro, que atualmente faz parte da Zona Sul da cidade de São Paulo. Ambos foram construídos com intervenções decisivas da empresa multinacional canadense Light and Power Company, que entrou no Brasil em 1899 demostrando sua enorme influência na configuração espacial desse espaço da cidade. 
A construção do reservatório Guarapiranga só pode ser compreendida em função do processo de modernização que passava a cidade de São Paulo.

O contexto de intensa urbanização e industrialização demandou o aumento de infraestrutura urbana e de geração de energia. Esta necessidade foi suprida com a construção do lago artificial da Guarapiranga (de 1906 a 1909) pela Light e constitui uma das primeiras grandes mudanças na região. Para fazer o lago, a Light adquiriu as terras que seriam inundadas com desapropriações, sob protestos dos proprietários, pois naquele momento as propriedades não eram valorizadas. (WHATELY, FERRARA, SANTORO, 2008, p. 34).

A ideia básica da construção de Guarapiranga era a regularização da vazão na usina hidrelétrica inaugurada em Santana do Parnaíba em 1910 a jusante do rio Tiete, do qual o Pinheiros é tributário. Com isso, a vazão poderia ser regularizada a jusante com as águas da represa recém-construída, no caso, a Guarapiranga; entretanto, havia uma necessidade enorme de água para o abastecimento público, o que fez com que, em 1928, a Guarapiranga fosse utilizada para esse fim, constituindo-se, nesse mesmo ano, no principal reservatório para o abastecimento público da cidade de São Paulo.

Figura 9. Obras durante a construção da barragem do reservatório Guarapiranga

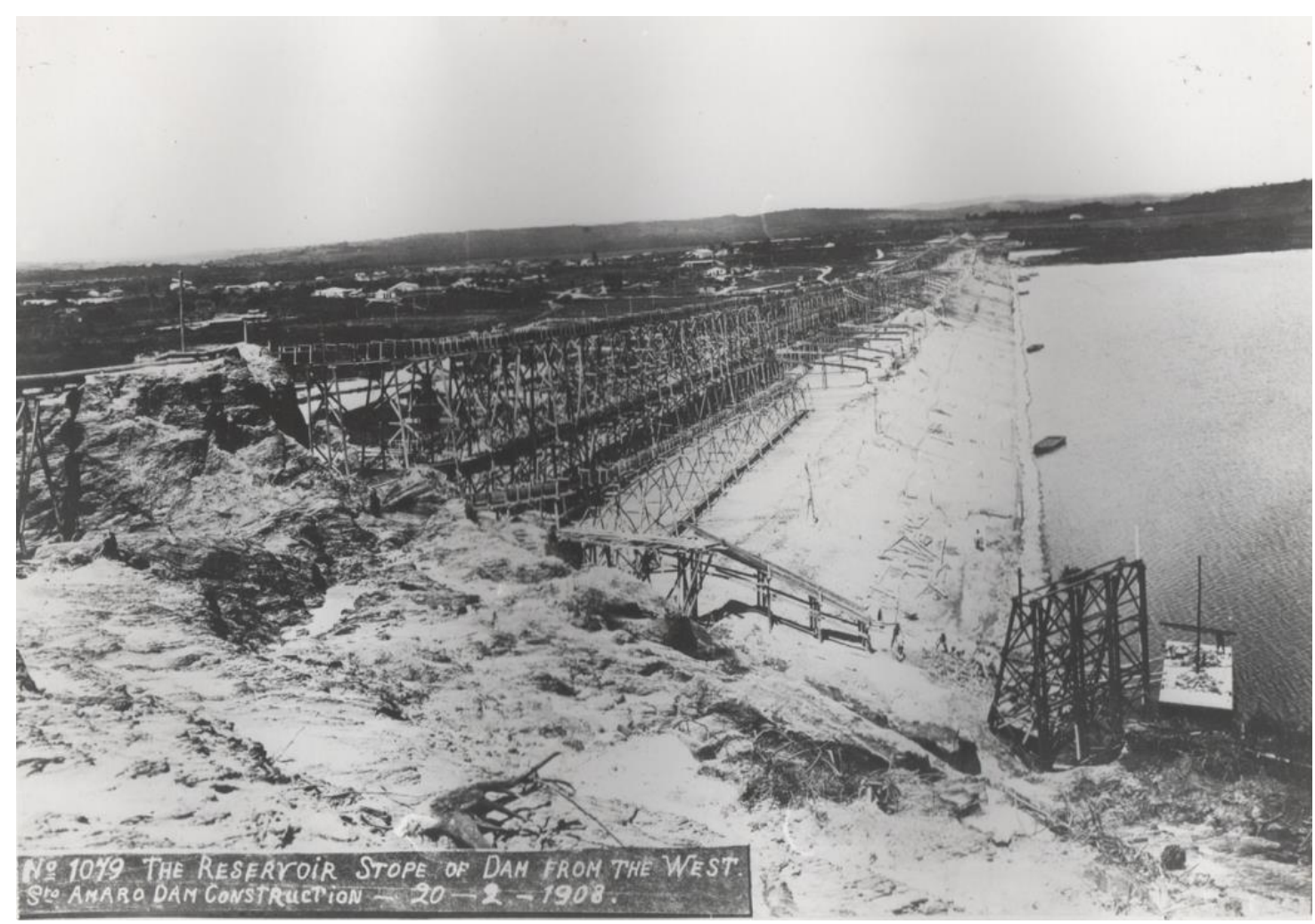

Foto: Construção da barragem do reservatório Guarapiranga em 1908. Fonte: Prefeitura Municipal de São Paulo (PMSP). Arquivo da Biblioteca Prestes Maia. 
É também desse período o surgimento de novas técnicas para tratamento de água e a obrigatoriedade de cloração da água, o que ocorre em 1926, demostrando a importância desse elemento para uma cidade que estava em pleno processo de desenvolvimento.

O conjunto de intervenções da Cia. Light em Santo Amaro não se limitou aos impactos provocados pela construção da represa de Guarapiranga. O ritmo veloz do crescimento de São Paulo, desde as primeiras décadas deste século, torna imperativa a ampliação do complexo produtor de uma das mercadorias essenciais a este ritmo de crescimento: a energia elétrica. (OLIVEIRA, 1996, p. 61).

Assim, foi necessário construir outro reservatório, muito maior que o de Guarapiranga: o reservatório Billings.

A represa Billings recebeu essa denominação oficial em 1949, em homenagem ao seu idealizador, o engenheiro Asa Kenney Billings. Ela é um imenso lago artificial resultante do barramento do rio Pinheiros, na altura de Pedreira, represando os seguintes rios: Grande (ou Jurubatuba), Pequeno, Capivari, Taquacetuba, Ribeirão Bororé, Ribeirão Cocaia, Córrego dos Alvarengas, entre outros de menor porte. (CETESB, 1997, p. 10).

Figura 10. Usina Elevatória de Pedreira

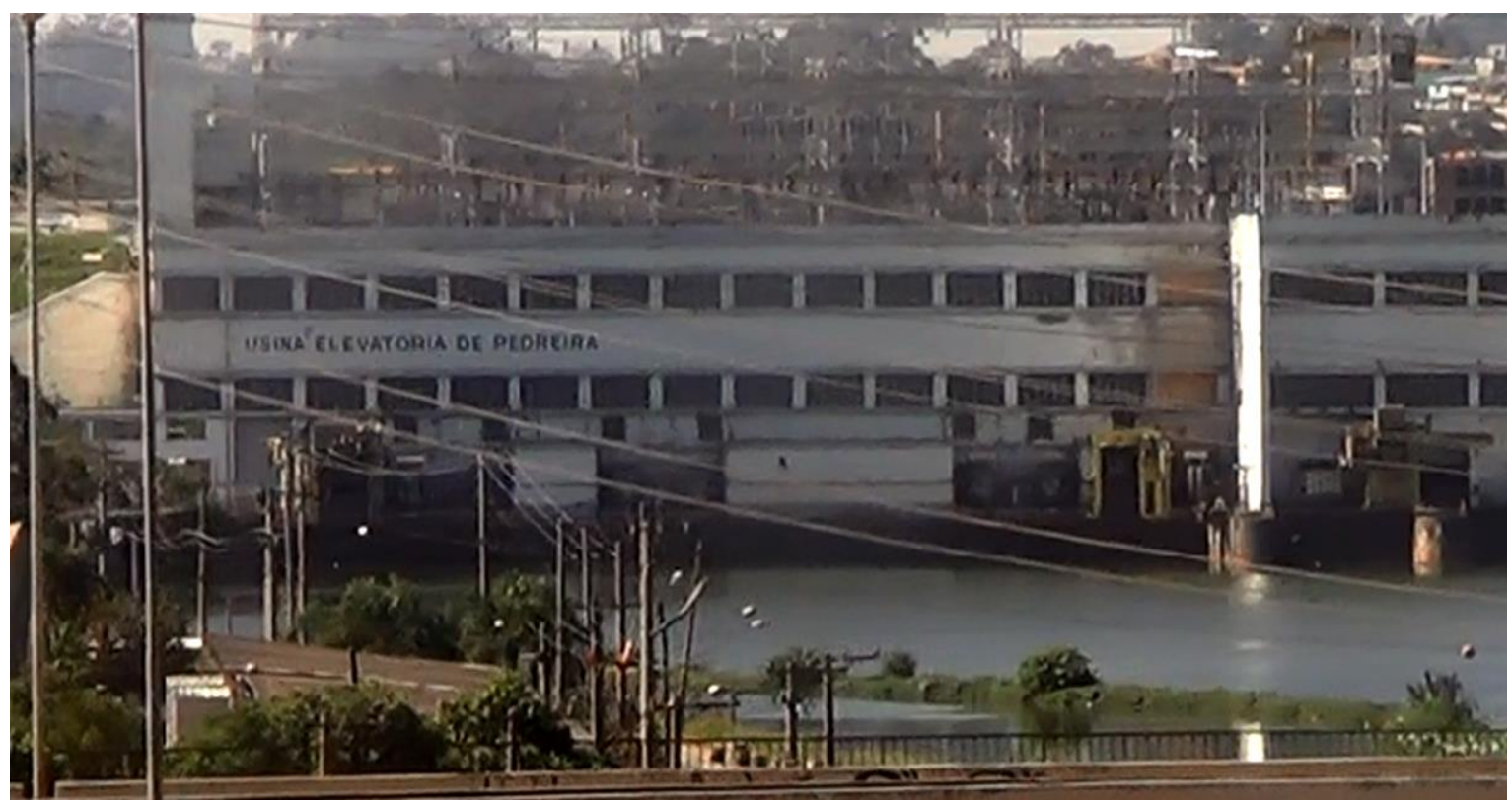

Vista da Usina Elevatória de Pedreira, 30 de abril de 2016. Foto do autor. 
Esse reservatório foi construído no período de 1925 a 1937, apresenta uma "área inundada de $127 \mathrm{~km}^{2}$ e o volume represado é de 1.200 milhões de metros cúbicos de água, a uma elevação de $728 \mathrm{~m}$ (com nível mínimo de água) a 746,5 m (com nível máximo de água) em relação ao nível do mar". (CETESB, 1997, p. 10).

Sua principal função era servir para a geração de energia elétrica ao sistema Henry Borden, que entraria em funcionamento na década de 1950. Além da construção do reservatório, fez parte desse grande projeto a retificação do rio Pinheiros e a construção de um novo canal por onde correria o leito do rio.

\footnotetext{
Cabe lembrar que a questão era de uma racionalidade muito avançada: era a compressão de que as obras em projeto ao mesmo tempo que integravam o circuito de capital produtivo de energia na sua forma material permaneciam fixados no espaço da cidade: alteravam substancialmente as possibilidades de uso da terra. (SEABRA, 1987, p. 168).
}

Foram realizadas várias desapropriações para a retificação do canal dos rios Tietê e Pinheiros. Nesse período, final da década de 1940, a urbanização ainda estava distante das bacias Guarapiranga e Billings, mas, segundo BUENO (1994, p. 74), "a permissão para a Light canalizar o Pinheiros e sanear as terras de sua várzea iria proporcionar a expansão da ocupação urbana na direção sul".

Isso não significou que poluição também estivesse distante do reservatório, uma vez que, ao contrário do que se apregoa comumente de que é urbanização da bacia que causa a poluição neste caso em especifico, foi um pouco diferente, pois a poluição chegou antes mesmo da urbanização da bacia. Tão logo o sistema de geração de energia da Usina Hidrelétrica de Henry Borden entrou em funcionamento, iniciou-se o recalque das águas fortemente poluídas para dentro do reservatório principiando o seu processo de poluição. 
Figura 11. Pedra inaugural da Usina Hidrelétrica Henry Borden, localizado no sopé da Serra do Mar, em Cubatão.

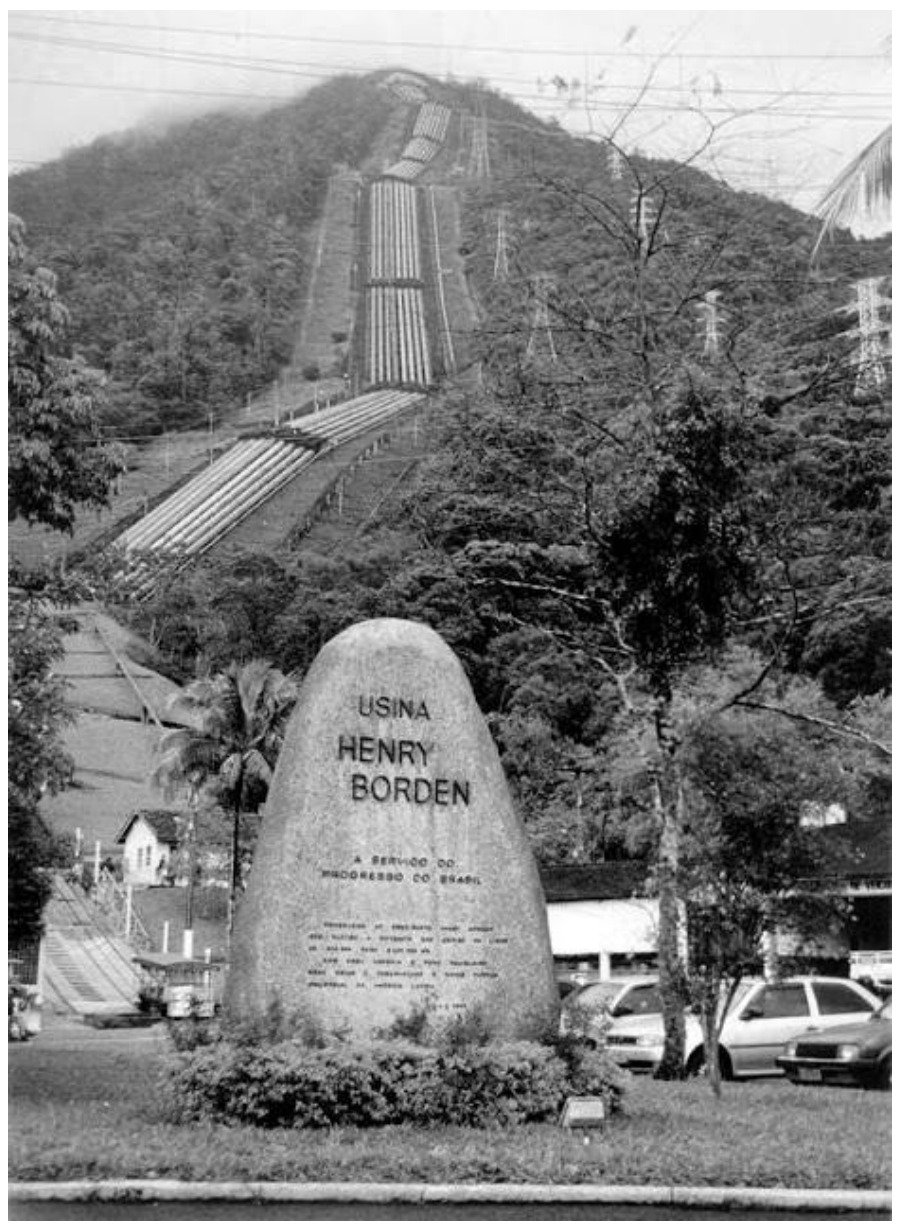

Foto: Vista da Usina Henry Borden, de Cubatão, em 1948. Fonte: <http://billingsrepresahistoria.blogspot.com.br/2012/10/historia-da-represa-billings-na-cidade.html>.

Cabe lembrar que, de acordo com OLIVEIRA (1996, p. 89), com a construção dos dois reservatórios e com a anexação de Santo Amaro, em fevereiro de 1935, "a perda de autonomia ligou de modo definitivo o destino de Santo Amaro ao da capital". Segundo consta, a anexação ocorrida deveu-se a dívidas do antigo munícipio de Santo Amaro com a cidade de São Paulo, o que propiciou a Santo Amaro integrar decisivamente e assumir o seu novo papel em relação à grande metrópole que se formava. Além do papel na estruturação da metrópole como grande fornecedor de energia, passou do antigo celeiro da metrópole para transformar-se no subúrbio residencial, com a ocupação das áreas próximas às belas paisagens dos lagos artificiais recém-criados, e posteriormente tornar-se, na fase de industrialização de São Paulo, periferia residencial da Zona Sul. 


\subsection{A política habitacional e a questão dos mananciais}

\subsubsection{A questão da habitação no período anterior aos anos 1970}

Durante um longo período, o problema habitacional dos trabalhadores não era questão de política pública importante para o Estado brasileiro.

\footnotetext{
$\mathrm{Na}$ República Velha, os setores sociais beneficiados pelo mercado rentista, sempre tiveram força para impedir toda a ação que prejudicasse o mercado de locação. A despeito dos discursos higienistas a respeito da precariedade das moradias, associando-se aos surtos epidêmicos, o Estado limitou-se à proposição de medidas de caráter legislativo, e, no âmbito da polícia sanitária, a reprimir situações mais calamitosas. (BONDUKI, 2004, p. 77).
}

Isso significa que até a década de 1930 o Estado não havia assumido a questão habitacional como uma política pública para a classe trabalhadora.

Os principais tipos de moradia nessa época na cidade de São Paulo, destinados a atender às classes mais baixas e setores médios da população, eram: os cortiços, as vilas operárias em menor número e as casas de correr, que formavam um conjunto de casas com um corredor que conduzia a elas no interior do terreno, todas produzidas pelo setor privado.

Enquanto o Estado tardava em tomar providências quanto à crise habitacional, que havia começado a partir das últimas décadas do século XIX, a população do município aumentou muito. Em números absolutos, subiu de 31.385 habitantes, em 1872, para 12.038.175 habitantes, em 2016, conforme mostra o gráfico abaixo. 
Gráfico 1. População do Município de São Paulo — 1872-2016

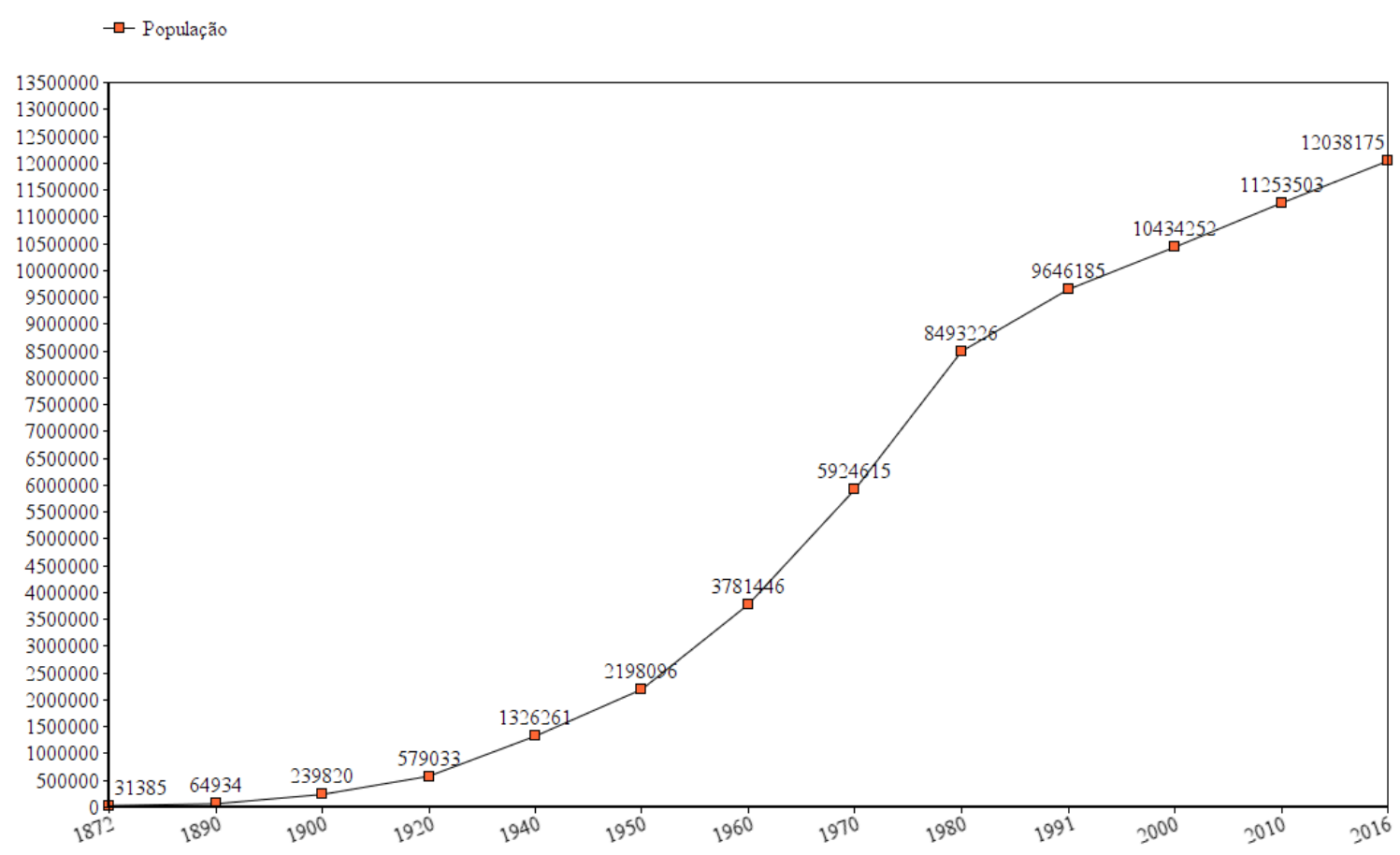

Fonte de dados: IBGE. Produzido pelo autor.

Diante desse quadro, apenas a partir da década de 1930 é que algumas iniciativas são tomadas por parte do governo para equacionar a questão da habitação para a classe trabalhadora.

O clima político, econômico e cultural durante a ditadura Vargas (19301945) colocou em cena o tema da habitação social com uma força jamais vista anteriormente [...] Embora continuasse presente, a questão sanitária passou para segundo plano nos debates sobre habitação social e surgiram novos temas, condizentes com 0 projeto nacionaldesenvolvimentista da era Vargas: primeiro a habitação vista como condição básica de reprodução da força de trabalho e, portanto, como fator econômico na estratégia de industrialização do país; segundo a habitação como elemento de formação ideológica, política e moral do trabalhador, e, portanto, decisiva na criação do homem novo" e do trabalhador-padrão que o regime queria forjar, como sua principal base de sustentação política. (BONDUKI, 2004, p. 73).

Como solução habitacional do período, o governo estimulou os Institutos de Aposentadorias e Pensões (IAPs), por meio do Decreto no 1.749, de 1937, que propiciou que os IAPs atuassem no campo habitacional. 
Coube assim, segundo COHN (1981, p. 15), aos institutos de previdência papel fundamental na expansão do capitalismo e da industrialização no Brasil em três frentes: "manutenção do consumo mínimo das classes de menor renda incapacitadas pelo trabalho por velhice, doença ou morte do chefe de família; elevação da capacidade de trabalho dos assalariados através da assistência médica; de fonte de recursos de investimento em diversos setores da economia", é claro que um desses setores foi a habitação de interesse social, dos conjuntos habitacionais.

Entre os conjuntos habitacionais que passaram a ser produzidos, alguns dos mais famosos foram o de Pedregulho, o da Gávea e o Conjunto Presidente Getúlio Vargas, todos no Rio de Janeiro. Eles acabaram sendo a única alternativa nesse curto espaço de tempo para tentar suprir a necessidade de construção de moradias para a classe trabalhadora. Tinham como marca o ideário da arquitetura moderna, inclusive do arquiteto alemão Walter Gropius, um dos principais nomes da arquitetura do século $X X$, que via a possibilidade de mudança do papel da mulher na sociedade, fabricando equipamentos como lavanderias coletivas, edificação de salas de reunião e de creches, ou seja, não era só produzir moradias, mas também urbanismo.

Figura 12. Conjunto Presidente Getúlio Vargas, Deodoro, Rio de Janeiro

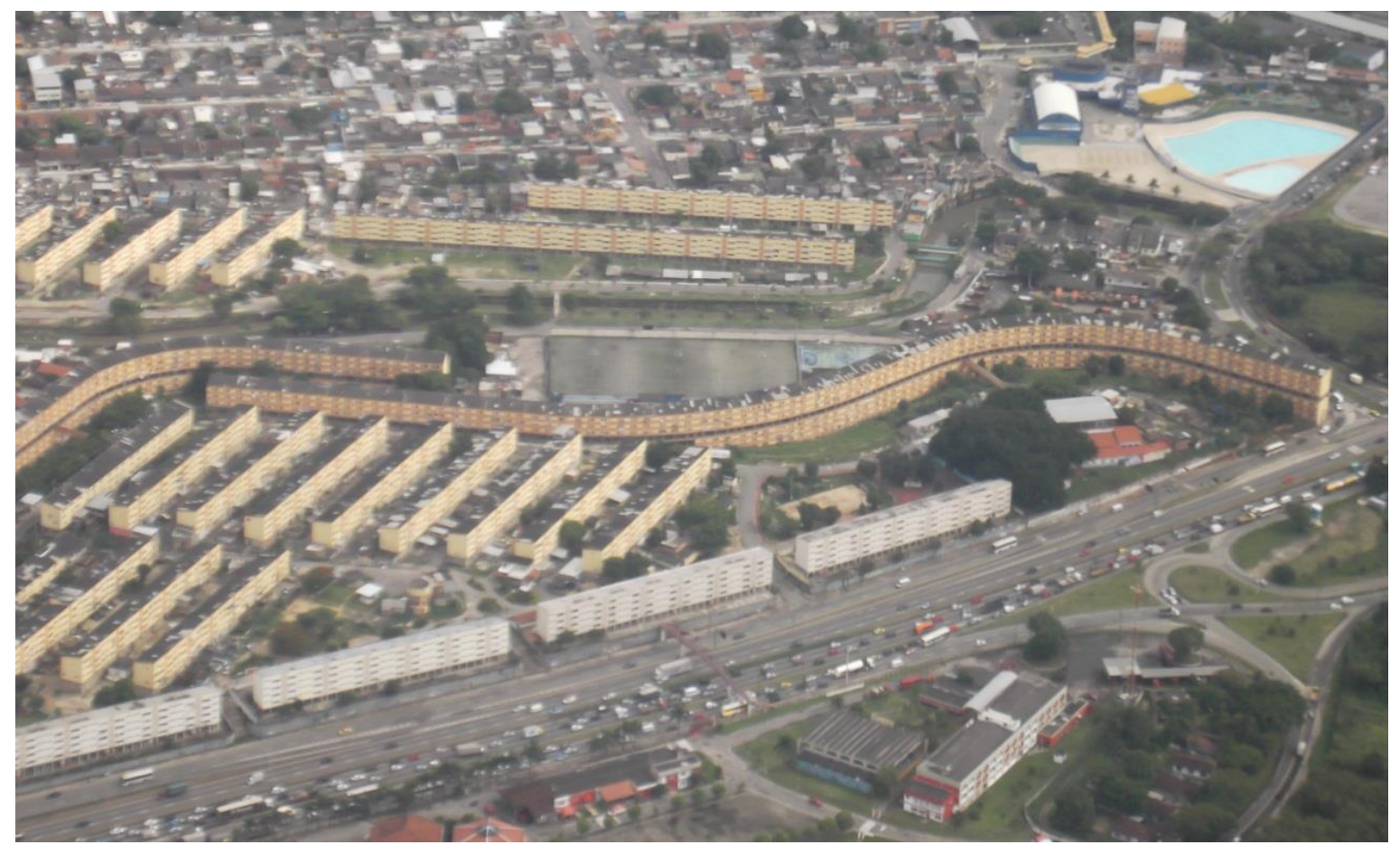

Conjunto Presidente Getúlio Vargas, Deodoro, Rio de Janeiro. Foto: Fabiano Leite da Silva, 2012. 
De acordo com RODRIGUES e SEABRA (1986, p. 41), "Um dos grandes problemas dos IAPs e de seu sucessor a Fundação da Casa Popular (FCP), fundada em primeiro de maio de 1946, foi a inexpressiva produção de unidades. Com a produção muito abaixo das necessidades que existiam nos centros urbanos". Para piorar, "os institutos também financiaram parte da produção imobiliária privada destinada à classe média". BONDUKI (2004, p. 128).

Além dessas iniciativas, o governo também atuou na área jurídica instituindo leis como a do Inquilinato de 1942, conforme descrito anteriormente que acabou produzindo uma onda de despejos em massa além de uma enorme redução de oferta de residências para locação durante o período em que esteve em vigor.

Não restavam muitas opções para os trabalhadores continuarem residindo nas regiões mais centralizadas da cidade. Isso os obrigou a encontrar terrenos mais baratos nas áreas mais distantes do centro. A busca por terrenos mais acessíveis pela população de baixa renda em contraposição à valorização de áreas centrais orientou o crescimento horizontal periférico.

Como as soluções estatais não foram suficientes para dar uma resposta à altura do problema habitacional, na década de 1940 surge uma outra opção para a classe trabalhadora, chamada padrão de ocupação periférica, baseada no tripé casa própria/autoconstrução/loteamento periférico, ou seja, a classe trabalhadora passa a ter que resolver por conta própria o problema de habitação, especialmente nas grandes cidades.

Isso resultou em um grande ônus social para os trabalhadores:

As famílias trabalhadoras têm se submetido a muitas privações para viabilizar obtenção da casa própria. São conhecidas as restrições a que submetem os trabalhadores de baixa renda que ingressam no processo de construção de sua casa própria: extensão da sua jornada de trabalho, autoconstrução à noite e nos fins de semana, rigorosas economias de salário, chegando até a convivência cotidiana com a fome, moradia em abrigos inacabados e sem habitabilidade, situados em longínquos loteamentos desprovidos de infraestrutura. Pelo menos $48 \%$ dos proprietários de baixa renda enfrentaram essas penas. Esse número pode ser ainda maior, porque mesmo os que contratam mão de obra (15\%) 
também se envolvem na construção e se sacrificam para pagá-la. (BRANT, 1989, p. 79).

O crescimento em determinadas áreas da cidade nesse período foi extraordinário. Para SACHS (1999, p. 50) "A periferia - particularmente os bairros mais pobres - conhece assim um crescimento bem mais rápido do que o centro [...] Durante os decênios de 1960 e 1970, vários bairros periféricos conheceram um crescimento explosivo".

A concentração de riqueza e população na região metropolitana de São Paulo não acarreta necessariamente melhores condições de vida para todos. Para BRANT (1989, p. 35) "a sobrevivência na cidade depende não só da proximidade de bens e serviços, que são abundantes, mas do acesso a eles, que é diferenciado segundo a disponibilidade de recursos financeiros".

Objetivamente, até meados dos anos 1960, as principais iniciativas para resolver os problemas habitacionais haviam se resumido em alternativas próprias dos trabalhadores como o pagamento de aluguéis nos cortiços no centro da cidade, a ocupação periférica, e por parte estatal aos IAPs e Fundação Casa Popular, além da via privada dos aluguéis, e das vilas operárias, que datavam do início de século e não supriram a demanda por habitação social como se fazia necessária.

\subsubsection{As alternativas habitacionais dos anos 1970 e a ocupação das áreas de proteção aos mananciais}

Durante a década de 1970, o modelo baseado na tríade autoconstrução/periferia/casa própria já não era mais capaz de absorver a enorme massa de trabalhadores que vinha tendo seu poder aquisitivo cada vez mais reduzido. Sendo assim, cabia mais uma vez aos próprios trabalhadores encontrar saídas para a crise habitacional que perdurava havia décadas e que só se agravava. As duas alternativas possíveis foram: a favela, que passa de ameaça a ordem; a solução habitacional de caráter definitivo; e o Banco Nacional da Habitação (BNH), que foi a forma de política habitacional escolhida pelo Estado brasileiro desde 1964 para resolver os problemas habitacionais e que ganha força definitivamente nos anos 1970. 
"Ao contrário do Rio de Janeiro, onde as favelas surgiram no início do século, em São Paulo elas foram um produto da crise da habitação na década de 1940". (BONDUKI, 2004, p. 261). Instaladas em áreas desocupadas no interior do tecido urbano, eram uma forma de resistência dos inquilinos em deixar as áreas centrais ou até de eliminar o custo da moradia no orçamento familiar (WHATELY; FERRARA; SANTORO, 2008, p. 37).

Até a década de 1970, a população que vivia em favelas era bastante reduzida no município de São Paulo, tanto que "até 1973 a porcentagem da população favelada sobre o total do município correspondia a 1\%" (SEMPLA, 1990). O seu aumento foi constante, atingindo um crescimento mais explosivo a partir da segunda metade da década de 1970. Enquanto a população da cidade cresceu 44\% entre 1970 e 1980, a população favelada cresceu 446\%. (RODRIGUES e SEABRA, 1986, p. 34).

Um dos dados novos que apareceram nos anos 1970 é que as favelas passam a ocupar não mais as áreas centrais das cidades, mas as periferias, e até áreas rurais. Segundo BRANT (1989, p. 92), "Na periferia, a tendência é a das favelas localizarem-se, às vezes, até por estímulo dos órgãos públicos, nas áreas de uso comum, vale dizer, áreas destinadas ao lazer, espaços verdes e equipamentos sociais dos loteamentos populares, além das zonas impróprias para ocupação, como beiras de córregos e terrenos de alta declividade. Os novos núcleos de favela são uma reprodução muito pior da moradia autoconstruída nos loteamentos precários. Por outro lado, a favelização das áreas reservadas a equipamentos institucionais e de recreação representa um ingrediente a mais na precariedade dos loteamentos populares".

Além disso, um dos maiores agravantes é que muitas dessas regiões onde foram se localizar as favelas estavam nas áreas de proteção aos mananciais.

Um aspecto de extrema gravidade é a localização dos núcleos de favelados nas áreas de mananciais. A Zona Sul da região metropolitana, onde há grande concentração de empregos, está em grande parte incluída na zona de proteção defendida pela Lei 898/75. A elevação do preço da terra pela enorme demanda existente na região e a legislação que impede a abertura de novos loteamentos e conjuntos habitacionais abaixo da linha dos mananciais expulsaram os mais pobres. Eles continuam dependentes 
dos empregos existentes. Assim a expansão das favelas continua a ocorrer na área que deveria ser preservada. (BRANT, 1989, p. 94).

Ao se referirem as causas do crescimento demográfico para Zona Sul de São Paulo, SÓCRATES, GROSTEIN e TANACA (1985, p.16) destacam que "os vetores de crescimento em direção às represas se devem a vários fatores, sendo os mais importantes a concentração de indústrias e serviços e, portanto, empregos na região e a disponibilidade de terra barata para a construção".

Para se ter uma ideia da importância da concentração das indústrias na Zona Sul, "Segundo dados do Serviço Nacional de Aprendizagem Industrial (1970-1980), $11 \%$ do total de empregos do Município estavam nas indústrias do distrito de Santo Amaro" (UEMURA, 2000, p. 54).

$\mathrm{Na}$ área de estudo não poderia ser diferente. Há o surgimento das primeiras favelas ainda no final dos anos 1970. MARICATO (2001, p. 39), ao comparar o processo de favelização no Rio de Janeiro e em São Paulo, concluiu que: "o processo de urbanização se apresenta como uma máquina de produzir favelas e agredir o meio ambiente".

Evidentemente, isso não se faz por culpa dos trabalhadores, que sofreram um arrocho salarial durante décadas, levando à perda de seu poder aquisitivo. Segundo matéria de SICSÚ (2014), da revista Carta Capital, "A ditadura durou 21 anos e, nesse período, o salário mínimo perdeu, em termos reais, mais de $50 \%$ do seu valor".

Esse fato também é constatado pelo gráfico do Dieese, elaborado em 2011, quando o salário mínimo completava setenta anos de sua instituição, conforme consta na reportagem de OLIVEIRA (2011), do Portal G1. Fica nítida a perda de poder aquisitivo dos trabalhadores entre 1960, período pouco anterior ao início da ditadura militar (1964-1985) e pouco depois do seu fim, em 1990. 
Gráfico 2. Evolução do salário mínimo (em R\$)

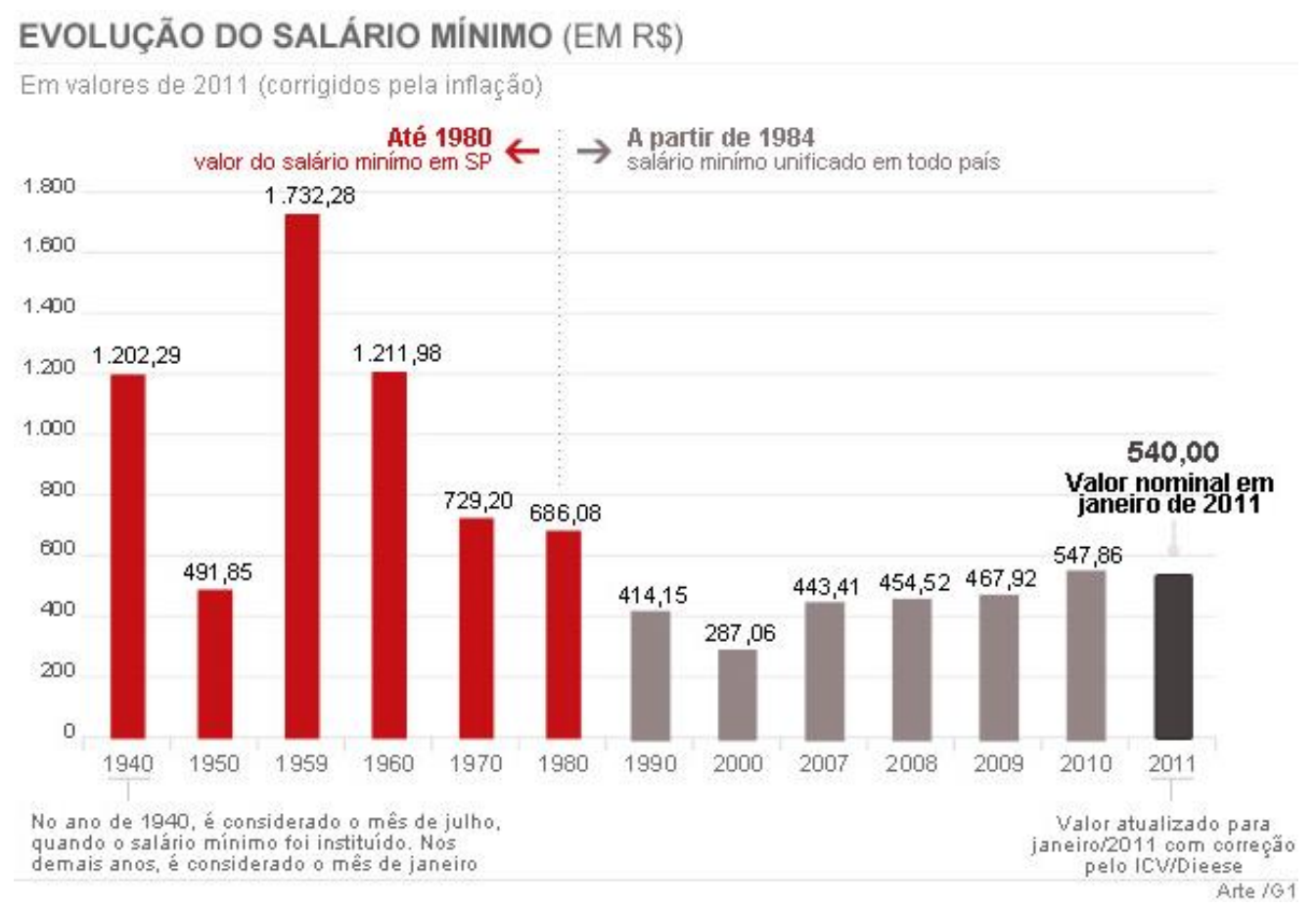

Fonte de dados: DIEESE, produzido pelo Portal G1, 2011.

O salário mínimo, que era de $\mathrm{R} \$ 1.211,98$, em 1960 , passa a valer somente $\mathrm{R} \$ 414,15$, em 1990, praticamente um terço do que valia trinta anos antes.

Além dos problemas macroestruturais mencionados, durante o período da ditadura, a falta de alternativas habitacionais que contemplassem a maioria dos trabalhadores, e a organização da cidade corporativa ao longo do tempo agravaram muito a questão social nas grandes cidades brasileiras. Como resultado desse processo aumentaram a espoliação e segregação socioespacial e a ilegalidade tornou-se a maior marca das grandes cidades brasileiras.

Nesse período, cresceram significativamente também nas periferias e áreas rurais, que foram sendo incorporadas ao tecido urbano a quantidade de casas para aluguel.

Isso foi mais um indício de que o modelo de expansão periférica baseada no trinômio casa própria/periferia/autoconstrução a essa altura não dava conta de resolver os graves problemas habitacionais. Nas décadas de 1990-2000, o problema agravou-se, pois, considerando as condições econômicas mais gerais do Brasil, já não era apenas o arrocho salarial que se fazia sentir na pele, mas a reestruturação produtiva com a saída de parte das fábricas da Zona Sul de São 
Paulo, especialmente instaladas no distrito de Santo Amaro e Capela do Socorro, no polo Jurubatuba, ao lado do final da marginal do rio Pinheiros.

A industrialização no Brasil é territorialmente muito concentrada e acompanha a tendência geral dos países de industrialização tardia. Investimentos maciços foram feitos para garantir as condições gerais da produção industrial, tais como energia, estradas, aparelhamento portuário. No entanto, há um limite para essa tendência à concentração a partir do qual se produzem deseconomias de escala, tais como a elevação dos preços dos terrenos e aluguéis, o congestionamento urbano e a oferta deficitária dos serviços públicos.

Dado que as áreas suburbanas passam a apresentar elevados custos dos terrenos a serem alcançadas por deseconomias de escala, comprometendo os custos de produção e a rentabilidade das fábricas, parte das indústrias passa a se transferi para o interior. "Em um raio de $150 \mathrm{~km}$ do centro metropolitano, ou seja, da cidade de São Paulo, a paisagem é marcadamente industrial. Cidades, quer de porte médio ou pequeno, expandem sua área industrial”. (LENCIONI, 1998, p. 30).

A metrópole estava, então, desconcentrando o setor produtivo, o chão de fábrica de suas indústrias, de setores de comando, mas isso não significou que estava acontecendo uma descentralização, pois as indústrias continuaram mantendo a centralidade do comando das funções na cidade de São Paulo, ou seja, na metrópole paulista.

Em termos econômicos isso significou mais desemprego especialmente na Zona Sul, que concentrava grande número de indústrias nesse período, e em termos espaciais um aumento maior nas ocupações nas periferias e nas zonas rurais, devido mais ao fator de empobrecimento da população com desemprego.

\subsubsection{A alternativa habitacional estatal - $\mathrm{O}$ BNH}

A grande alternativa habitacional via estatal oferecida aos trabalhadores de 1964 até meados dos anos 1980, especialmente para os operários urbanos em todo o Brasil, foi o Banco Nacional da Habitação (BNH), criado pela Lei 4.380 de 2/08/1964. Essa lei, que instituiu tanto o BNH quanto o Sistema Financeiro da Habitação (SFH), significou que a política habitacional do Estado assumia o modelo 
empresarial. A problemática da habitação passa a sofrer a intervenção do Governo Federal, que propõe a coordenar a ação dos órgãos públicos e privados com o objetivo de estimular a produção de habitações e oferecer financiamento para as faixas populares. A captação de recursos do BNH é realizada por meio do Fundo de Garantia por Tempo de Serviço (FGTS) e de cadernetas de poupança.

O mercado habitacional foi seccionado com a divisão do trabalho entre diferentes agentes (públicos e privados), sob o comando do $\mathrm{BNH}$, atendendo a cada agente especifico a um dos agentes do mercado. $\mathrm{O}$ mercado para famílias com renda mensal até 5 salários mínimos é atendido pelas COHABs; para famílias entre 3 a 8 salários mínimos, o atendimento é basicamente através das cooperativas habitacionais. $\mathrm{O}$ mercado acima dessa faixa é atendido pelo sistema financeiro de habitação (SBPE), integrado pelas Caixas Econômicas em suas carteiras de habitação, pelas sociedades de Crédito Imobiliário (SCI) e as Associações de Poupança e Empréstimo (APE). (Rodrigues e Seabra, 1986, p. 43).

As bases políticas, ideológicas, econômicas do $\mathrm{BNH}$ se assentam em:

uma política habitacional que emerge com a proposição de diminuir o déficit habitacional e gerar novos empregos com aumento das construções. Como a indústria da construção civil utiliza mão de obra em larga escala, incentivar a indústria da construção civil é também tentar atenuar a crise econômica. Ao mesmo tempo difunde mais a ideologia da "casa própria", contribui para a "estabilidade social" e torna os proprietários "aliados da ordem" como disse o então Ministro Roberto Campos. (RODRIGUES, 1990, p. 57).

Várias dessas proposições elaboradas para o BNH não se concretizam, por exemplo a questão a destinação dos recursos relacionada a produção da moradia popular, para as faixas de população de mais baixa renda que deveriam ser priorizadas utilizando-se os recursos do FGTS, não foram cumpridas, "quando se considera volume de recursos, o predomínio será para as faixas médias e altas, e também para as chamadas obras de desenvolvimento urbano (Cura, Planasa, Metro, Ponte Rio-Niterói). (RODRIGUES e SEABRA, 1986, p. 43).

Mesmo assim há de considerar o impacto das políticas públicas do $\mathrm{BNH} / \mathrm{Cohabs}$, o que podemos denominar desestruturação das cidades brasileiras, especialmente como estou tratando aqui do município de São Paulo, da Zona Sul, 
subdistrito do Grajaú, com a construção do BNH/Cohab Brigadeiro Faria Lima, um enorme empreendimento estatal habitacional, instalado pelo governo em 1973. Esse enorme equipamento habitacional foi instalado em uma área que apresentava características rurais, com o agravante de estar na área que viria a ser considerada como área de proteção aos mananciais, e de ocupação restrita, com possiblidade de causar um enorme impacto no aumento demográfico da região, questão que esse próprio governo discutia em planos que não deveria ser ocupada ou ocupada com densidades baixas.

Um desses planos era o Plano Metropolitano de Desenvolvimento Integrado (PMDI), de 1971, já citado anteriormente, em que pese as críticas tem o mérito:

de ser o primeiro que encaminha uma abordagem metropolitana para os problemas de São Paulo [...] inclusive proposições relacionadas com a preservação dos mananciais, o redirecionamento da cidade do vetor sul para o vetor leste, a necessidade de uma legislação metropolitana para proteção aos mananciais e o plano de esgotos para a grande São Paulo, conhecido como Solução Integrada. (SÓCRATES, GROSTEIN e TANACA, 1985, p. 63-64).

A década de 1970 ficaria dessa forma marcada pelo conflito entre normas e ocupação do espaço, conflitos esses causados e até agudizados pelo próprio poder estatal.

\subsection{As áreas de proteção de mananciais: normas e formas de ocupação}

\subsubsection{Modelo cívico econômico}

O modelo cívico econômico revelou-se um fator importante para o crescimento das cidades brasileiras pós-1964. Um modelo econômico de caráter concentrador, levando a uma enorme concentração de renda e empobrecimento progressivo da população, este conjugado ao modelo cívico, com total repressão aos direitos civis. Pois,

A noção de direitos políticos e de direitos individuais teve que ser desrespeitada, senão frequentemente pisoteada e anulada. Sem esses pré-requisitos, seria impossível manter como pobres milhões de brasileiros, cuja pobreza viria a ser criada pelo modelo econômico anunciado como redentor. Aliás, muitos pobres que acreditaram nos 
slogans com que se popularizou o discurso cientificista dos economistas do regime, acabaram ainda mais pobres. (SANTOS, 1987, p. 3).

As análises de Chico de Oliveira podem completar essa ideia, desenvolvida pelo professor Milton Santos, pois para ele (Chico de Oliveira) não são os setores atrasados brasileiros que geraram um quadro de pobreza atual, especialmente se pensarmos a questão da qualidade de vida nas grandes cidades brasileiras para a maioria da população, mas foi o próprio processo de modernização que gerou a crise atual.

"No Brasil", de acordo com OLIVEIRA, (2008, p. 32), "o moderno cresce e se alimenta da existência do atrasado". No caso da agricultura, ela teve dois papéis: um externo de manter divisas para a industrialização e um interno de manter o preço dos alimentos relativamente baixo, evitando a escassez nas grandes cidades. Esse processo de modernização incompleta de crescimento sem justiça social gerou um cenário de crise das cidades brasileiras, que foi se agravando ao longo de décadas e se acentuou mais a partir de meados da década de 1970 e anos 1980.. Com uma industrialização e crescimento gestado com base na concentração de renda e empobrecimento da população, num quadro recessivo dos anos 1980 1990, a situação do trabalhador foi piorando. Diante dessa realidade, poderíamos reafirmar a tese de SANTOS (1990, p. 15) em que: "A pobreza é estrutural e não residual. Ela aumenta à medida que a cidade cresce".

Os reflexos do modelo cívico econômico sobre o território foram notáveis, produzindo uma cidade completamente desumana e desigual para a maioria de seus habitantes. É interessante notar que: "[...] mesmo antes da conjuntura de crise de 1981-1983, o modelo de crescimento implantado no País alijou a imensa maioria dos benefícios de uma sociedade que teve notável crescimento econômico". (KOWARICK, 2009, p. 20).

Dessa forma, sem direitos políticos, sem a participação popular, sem alternativas para o problema da habitação e com uma legislação cada vez mais restritiva, os trabalhadores tiveram grandes dificuldades em encontrar lugares para morar nas grandes cidades brasileiras, neste caso dentro do munícipio de São Paulo. 


\subsubsection{A questão da normatização dos anos 1970 com as leis específicas de áreas de proteção aos mananciais}

Durante a década de 1970, começam a surgir preocupações ambientais em relação a diversos elementos da natureza, entre eles um recurso fundamental: a água. Iniciou-se um debate a respeito do crescimento urbano nas áreas de proteção aos mananciais, e uma quantidade relativamente grande de material foi produzida em relação ao assunto.

Surge na cidade de São Paulo o primeiro Plano Metropolitano de Desenvolvimento Integrado (PMDI), de 1970, que procurava reorientar o crescimento da cidade, priorizando o crescimento no sentido Leste-Oeste. Surgem também nessa década as primeiras leis específicas de proteção aos mananciais da cidade de São Paulo, que são as Leis de no 898/75 e no 1.172/76.

A essência da Lei ํo 898/75, que disciplina o uso de solo para a proteção dos mananciais, cursos e reservatórios de água e demais recursos hídricos de interesse da Região Metropolitana da Grande São Paulo e dá providências correlatas, pode ser resumida como áreas de proteção as dos reservatórios Billings, Guarapiranga e Cantareira na declaração do seu artigo $2^{\circ}$, ou nos termos da lei:

Art. 2 - São declaradas áreas de proteção e, como tais reservadas, as referentes aos seguintes mananciais, cursos e reservatórios de água e demais recursos hídricos de interesse da Região Metropolitana da Grande São Paulo:

I - Reservatório Billings;

II - Reservatórios do Cabuçu, no rio Cabuçu de Cima, até a barragem no Município de Guarulhos;

III - Reservatórios da Cantareira, no rio Cabuçu de Baixo, até as barragens no Município de São Paulo;

IV - Reservatório do Engordador, até a barragem no Município de São Paulo;

V - Reservatório de Guarapiranga, até a barragem no Município de São Paulo. 
Já a lei do ano seguinte, a Lei № 1.172/76, ratifica as áreas estabelecidas na Lei no 898/75 e as delimita com maior rigor estabelecendo categorias de uso desde mais restritivos que seria a faixa 1 , por exemplo, quando cita em seu $2 \circ$ artigo, inciso II - a faixa de 50 metros de largura, medida em projeção horizontal, a partir da linha de contorno correspondente ao nível de água máximo dos reservatórios públicos, existentes e projetados, proibindo o uso dessa faixa próxima aos reservatórios.

Pelo menos na intenção aparente:

as leis estaduais foram criadas para a proteção dos mananciais após a constatação da utilização de praticamente toda a disponibilidade hídrica da bacia hidrográfica do Alto Tietê, a importação de águas da bacia do rio Piracicaba e a necessidade de ordenamento do crescimento urbano. Essas leis consideravam a ocupação urbana da bacia como principal fator para a má qualidade da água e para evitar a ocupação e preservar o ambiente, ora restringiam totalmente novas ocupações, ora propunham ocupações pouco adensadas, com grandes áreas permeáveis. (WHATELY et al., 2009, p. 41).

As leis definiam, por exemplo, o tamanho mínimo dos terrenos para serem ocupados. A medida mínima era de 500 metros quadrados, entre outras restrições ao uso e ocupação do solo. No entanto, na prática o efeito foi exatamente o contrário do que propunha as leis de proteção aos mananciais, já que houve um adensamento ainda maior de população nessa área, após justamente a promulgação das referidas leis. Por que será que isso aconteceu?

Um dos principais motivos foi o seu pressuposto, pois ela questionava a ocupação irregular da bacia, responsabilizando as pessoas que moravam no lugar como os causadores da poluição, daí o seu caráter sempre policialesco sempre reivindicando mais leis, fiscalização e mais punição às pessoas que ocupavam o local, culpando e expulsando os moradores das áreas de proteção de mananciais, ou mais tarde propondo, como na maioria dos projetos desenvolvidos para estas áreas durante os anos 1990, soluções pontuais com intervenções apenas locais tentando resolver os sintomas como se a cidade fosse um paciente doente, sem enfrentar as verdadeiras causas do problema de poluição dessas áreas, ou ainda pode ter sido a extrema confiança no poder da norma jurídica. 
No meio técnico firmou-se a crença de que a regulamentação da lei de proteção em 1976 e sua aplicação seria suficiente para deter o crescimento da cidade. (SÓCRATES et al. 1985, p. 28).

Isso causou sérios problemas desde a desconsideração da cidade real, pois criou-se uma lei que parecia querer congelar o avanço da urbanização sobre as áreas de proteção aos mananciais no momento da sua criação, desconsiderando todos os processos e agentes urbanos envolvidos, além de criar uma série de obstáculos à ocupação da área, o que parecia ser um avanço, mas que em contrapartida não criou alternativas para a ocupação local, conforme fica claro nas palavras de Alberto Botti:

No caso da Lei de Proteção aos mananciais houve, ao longo do tempo, uma preocupação muito grande em criar "não usos" em torno dos mananciais, isto é, de se especificar o que não se poderia fazer. Nunca, tentamos, para valer, até que ponto podem existir usos competitivos, ou o que podemos fazer para que os usos tradicionais se tornem competitivos. (SOCRÁTES et al, 1985, p.130).

É interessante não ter-se levantado a questão do porquê que as pessoas estavam lá, e mais ainda não ter relacionado a questão de ocupação das áreas de proteção aos mananciais à crise econômica iniciada em meados dos anos 1970, que perdurou durante décadas, e que empurrou literalmente os expropriados da cidade para áreas que acabaram pela própria lei sendo desvalorizadas pelo mercado formal de terras, ou seja, o que havia era uma crise estrutural do capitalismo brasileiro que rebatia sobre as cidades com uma das suas facetas mais perversas: a falta de habitação popular para trabalhadores.

Ao mesmo tempo em que se deu a promulgação da lei, houve uma certa tolerância a essa ocupação, ou nas palavras de Maricato, que considera ser:

impossível admitir o contrário, pois se essa gigantesca ocupação de terras não fosse tolerada e a população pobre ficasse sem alternativa nenhuma, teríamos uma situação de guerra civil, considerando os números envolvidos. Não é a norma jurídica, mas a lei de mercado que se impõem, demostrando que nas áreas desvalorizadas ou inviáveis para o mercado (beira de córregos, áreas de proteção ambiental, por exemplo) a lei pode ser transgredida. $O$ direito à 
invasão é até admitido, mas não o direito à cidade. O critério definidor é do mercado ou da localização. (MARICATO, 2001, p. 161).

Por melhor que pudessem ter sido as intenções de alguns legisladores que propuseram na época as leis de proteção aos mananciais, o seu resultado em si foi desastroso. Os anos 1970 marcaram o reconhecimento do movimento ambiental, mas agora os anos 1990 a sua tomada de ações falta o movimento ambiental e urbano se articular em um movimento que lute pelo direito à cidade e não pelo direito ambiental e urbano, separadamente, não se lute apenas contra a espoliação urbana, mas contra a espoliação urbano-ambiental, esta é a grande questão do início do milênio atual.

\subsubsection{As duas agendas políticas que "não se encontram"}

Um ponto crítico é o do encontro de duas agendas, que andam distantes e separadas praticamente de três a quatro décadas, e que, recentemente, por esforço de alguns grupos, agentes sociais e intelectuais, começam a se encontrar.

A agenda urbana, com toda a sua pauta de reinvindicações, e a agenda ambiental, o que Martins chama a atenção para o que seria o Direito Urbanístico e Ambiental,

cuja pedra fundamental é o bem comum a prevalência do interesse coletivo sobre o interesse privado. $O$ sujeito desse direito o povo, uma indeterminação de sujeitos, que se expressa como interesses difusos. (MARTINS, 2007, p. 10).

Assim, o direito urbano e a sua pauta de reivindicações não podem ficar deslocados do direito ambiental, como tem sido muito comum até os dias atuais.

No Brasil, um dos maiores exemplos é o das leis de proteção aos mananciais, e as reivindicações urbanas de ambas agendas permaneceram como opostas desde os anos 1970 até o final dos anos 1990, em que questões como moradia e preservação de áreas de mananciais pareciam se opor, o que é verdade para muitos até hoje. Na realidade, são questões irmãs, uma relacionada à outra e viceversa, que devem ser tratadas de maneira mais integrada. 
A interpretação de que questão ambiental é uma coisa e questão urbana é outra nas cidades infelizmente ainda perpassa na visão de muitas secretarias de estado, cujos técnicos ligados ao meio ambiente veem os moradores das áreas de proteção aos mananciais como invasores. Em discursos oficiais, as verdadeiras causas que levam a ocupações das áreas de proteção de mananciais são omitidas, como a expulsão dos pobres das regiões mais valorizadas da cidade devido ao alto preço dos imóveis e dos aluguéis, a dificuldade ao longo da história das políticas habitacionais incorporarem as parcelas mais pobres da população em programas oficiais de governo, além do tratamento dado pela mídia em geral a esse assunto da ocupação das áreas de proteção de mananciais, que, em vez de ajudar a promover um amplo debate público, suscitam o ódio contra os moradores dessas áreas, sempre usando da mesma retórica de que o problema da poluição é causado pelo esgoto que é jogado na represa devido a ligações clandestinas das pessoas que invadem os terrenos e constroem moradias ilegais nas áreas de proteção aos mananciais.

Poucas vezes, ou quase nunca, se relaciona o problema da poluição à questão da falta de opções de moradia para a população que vive em áreas de proteção aos mananciais, principalmente os mais pobres, tanto na cidade de São Paulo, como nas cidades brasileiras e por que não dizer da América Latina.

O discurso a respeito da poluição e da criminalização das ocupações, com a sugestão de expulsão dos moradores, é a postura mais recorrente, tanto para combater quanto para resolver o problema, evitando dessa maneira discutir a questão a fundo. Em um Estado patrimonialista, a terra ainda é sinônimo de poder no Brasil. Poderíamos pensar que isso ocorre apenas em áreas agrícolas, mas isso, na verdade, ocorre sobretudo em áreas urbanas, que concentram a maior parte da população brasileira.

Os problemas referentes à Agenda Urbana e à Agenda Ambiental não podem mais serem tratados de modo separado, como algo que se sabe da sua existência que são do mesmo "sistema", mas que nunca se encontram, ou como problemas paralelos que correm juntos. É de suma importância que haja mudança na abordagem para as questões ambientais e urbanas, e tratá-las de maneira conjunta. 
Acselrad (2009) nos dá um bom exemplo do que acontece quando as duas agendas se encontram, ao narrar um episódio que ocorreu nos Estados Unidos. $\mathrm{O}$ movimento ambientalista era dominado pela classe média branca, os negros lutavam por reivindicações urbanas, até:

que depois de um longo período de afastamento da discussão ambiental, particularmente daquela das grandes entidades ambientais americanas, de uma distância desconfiada ou com divergência entre as respectivas causas, "afinal" descobriram uma forte dimensão ambiental em suas lutas. Tudo isso nasceu de um certo número de ações coletivas contra a localização dos depósitos de lixo tóxico nas áreas de moradias das comunidades negras. Essas lutas implicariam confrontos isolados, que justificaram em seguida a hipótese de que haveria alguma lógica em unilos, lógica essa localizada no interior da política de localização do lixo tóxico - mesmo que não evidenciada - que levava com que coincidissem o mapa de localização do lixo tóxico e o da moradia das comunidades negras. Os movimentos fizeram essa relação causal, dando lugar a uma pesquisa que, após fazer todo o mapeamento do território dos EUA, confirmou a coincidência denunciada: onde havia lixo tóxico era onde se concentrava a população pobre e negra... organizou-se um movimento nacionalmente e estabeleceu uma ligação entre as noções de justiça e de meio ambiente. Incorporou-se, assim, uma dimensão ambiental em suas lutas, dizendo que para eles a questão ambiental era uma questão de vida ou morte, quando até então se considerava que a questão ambiental, tal como formulada pelos movimentos de classe média, ligava-se mais às representações de natureza e unidades de conservação. Houve então uma aproximação desses dois movimentos, e mudou o paradigma que orienta a organização social engajada nas lutas ambientais. (ACSELRAD, 2009, p. 32).

Com o conhecimento desses fatos descritos acima passou-se à luta não apenas por melhorias urbanas, mas ambientais a partir da conclusão de que os pobres estavam mais expostos aos riscos ambientais. Como disse Acselrad (2009), essa consciência nasce da noção de justiça ambiental que vai substituir a outra visão que vinha do Clube de Roma: "Mais preocupada com a continuidade da acumulação capitalista, com as possibilidades de que algum tipo de ruptura nas fontes de aprovisionamento de insumos pusesse em risco a continuidade do próprio 
capital". (Acselrad, 2009, p. 22). Essa noção de sustentabilidade visava a preservação do que convém e quando convém ao grande capital para manter a exploração, para não levar ao esgotamento os recursos naturais, e no limite, como foi dito anteriormente, garantir as condições para a reprodução do próprio capitalismo, perpetuando a sua existência.

No caso da poluição do reservatório Billings, ainda não foi tratado como uma questão de justiça ambiental, pois são os mais pobres que sofrem diretamente com os efeitos dessa poluição, desde os anos 1940 conforme veremos mais adiante.

\subsection{A poluição do reservatório}

A história de poluição do reservatório começa tão logo terminam as obras de retificação dos canais do rios Pinheiros e Tietê, em 1949, quando foram concluídas as obras de reversão (instalação de turbinas reversivas e elevação da crista da barragem de Santana do Parnaíba, a jusante de São Paulo) e a conclusão do sistema de bombeamento em Traição e Pedreira, que, a partir de 1950, começa a recalcar as águas fortemente poluídas do Tietê, através do canal do Pinheiros, também receptor de esgotos da cidade para a represa Billings.

\footnotetext{
Quase ao mesmo tempo, iniciou-se o processo de eutrofização com o aparecimento de algas, formando massas flutuantes, algumas dessas algas inclusive potencialmente tóxicas, em seguida houve o déficit de oxigênio, dando origem a áreas com manchas anaeróbias, no início próximas a barragem logo depois atingindo lugares cada vez mais distantes. (CETESB, 1997, p. 10).
}

Outro dado importante, são algumas alterações na utilização da represa e na sua conformação, que foram se processando ao longo dos anos. Esse fato alterou o seu regime, por exemplo: a construção de um aterro, durante a década de 1940, interceptando parcialmente o braço Jurubatuba ou do rio Grande na localidade denominada de Riacho Grande, para a ultrapassagem de uma nova rodovia na época, Via Anchieta, que ligaria São Paulo à cidade de Santos. 
Outra alteração foi em 1950, quando foi construído o sistema para o abastecimento de água dos municípios do $\mathrm{ABC}$, com a retirada de água no mesmo rio Grande imediatamente à montante do aterro.

Esse sistema, que entrou em operação em 1958, defrontou-se logo com o problema - não previsto - da eutrofização A essa altura já provocava a formação de massas tóxicas, muito densas de algas cianofíceas, algumas potencialmente tóxicas, junto ao ponto de tomada da água. (CETESB, 1997, p. 10).

Em função disso, foram realizados os primeiros estudos sobre a poluição no local e talvez sobre a própria poluição dentro da represa, pelo DAE, em 1958-59, que resultaram num amplo levantamento sanitário e ecológico de 1964-1965 publicado em 1966, indicando que era conveniente o fechamento do braço do rio Grande junto da Via Anchieta para proteger as águas da influência de esgoto da jusante, obra que só foi realizada em 1982 mediante a construção da barragem Anchieta.

Em meados da década de 1970, aumentava o grau de poluição da represa Billings devido à intensificação do processo de urbanização da cidade de São Paulo e de vários de seus municípios vizinhos, entre eles os do $A B C$, com todas as suas graves implicações, o que provocou da parte do Governo Federal a atitude de determinar que fossem realizados estudos pelo governo de São Paulo, visando estabelecer medidas que pudessem diminuir os efeitos causados pela poluição.

Esses estudos originaram a primeira regra operacional para o sistema, adotada a partir de fevereiro de 1975 e aplicada até 1977, a qual introduziu o chamado Parâmetro (relação entre a área do reservatório que apresenta anaerobiose na superfície das águas e a área total da represa), o qual relacionava os seguintes fatores:

1. A extensão da mancha anaeróbia com a intensidade das chuvas;

2. A vazão recalcada em Pedreira;

3. A vazão turbinada em Henry Borden, além de alguns outros parâmetros climáticos. 
Mas, em síntese, a vazão bombeada em Pedreira poderia ser estabelecida em função da bombeada em Henry Borden. Isso ainda mostra o quanto teríamos de avançar no sentido da preservação ambiental. O pensamento imbuído do espírito desenvolvimentista da época era o de que não seria preciso bombear tão constantemente, mas apenas o que as indústrias de Cubatão necessitassem; a prioridade eram as empresas que dependiam da geração de energia elétrica, e não a qualidade efetiva das águas, quanto mais a qualidade de vida da população da metrópole. Essas questões começavam a ser discutidas desde 1972, na primeira Conferência Mundial sobre o meio ambiente, realizada em Estocolmo, na Suécia, mostrando já a preocupação com a qualidade de vida e surgindo daí programas sociais que incluíssem a preservação ambiental.

Em suma, apesar dessas importantes considerações feitas aqui, o recalque em Pedreira ainda era determinado em função das necessidades da Usina Hidrelétrica Henry Borden e da geração de energia para Cubatão.

Em 1983, realizou-se uma experiência interessante proposta pela Cetesb, com o apoio da Sabesp e da Eletropaulo. Essa operação recebeu o nome de Operação Saneamento, que surgiu por pressões de diversas entidades, que já davam conta do enorme problema que é a poluição, e consistiu em suspender pelo período de três meses o recalque das águas do Tietê-Pinheiros para a represa Billings, com o objetivo de verificar os efeitos que essa medida provocaria sobre as características ecológicas e sanitárias da represa, assim como avaliar sua capacidade real de autodepuração. Esse trabalho permitiu a recuperação do reservatório em um curto espaço de tempo.

Em 1984, a Operação Saneamento foi substituída pela Operação Balanceada, que consistia no envio de $50 \%$ das águas do rio Tietê para a Billings e de $50 \%$ para o Médio Tietê. Com a retomada do bombeamento em Pedreira, observou-se novamente uma queda nas condições sanitárias do reservatório Billings.

Em 1992, como consequência das obras destinadas a reduzir as enchentes na cidade de São Paulo, através do aprofundamento da calha do rio Tietê, a jusante da confluência com o rio Pinheiros, $100 \%$ das águas foram destinadas para a 
represa Billings, executando uma descarga mínima a título de se efetuar um controle sanitário básico, que seguia o curso natural do rio Tietê.

Com base em dispositivo da Constituição Estadual, resolução conjunta da SMASES-3, de 1992, suspendeu o bombeamento das águas do rio Pinheiros para a represa Billings. Isso possibilitou que os Secretários da Energia e Saneamento determinassem que o bombeamento só seria retomado em situações de emergência quando recomendado para evitar danos a pessoas e bens, em decorrência do excesso ou falta de água no sistema hídrico da Bacia do Alto Tietê e Bacias Integradas.

Pela primeira vez, levou-se em conta o meio ambiente, no caso, a represa, favorecendo não só a população que mora ao redor do reservatório, como também aquela que consome e usufrui dessa água. Preservar os mananciais significa preservar a própria qualidade de vida dos seres humanos.

São definidas as seguintes situações como emergências, para que possa ser realizado o bombeamento:

1. O aumento de vazão do rio Tietê, no ponto de sua confluência com o Pinheiros, acima de $160 \mathrm{~m} / \mathrm{s}$, ou previsão de precipitações pluviométricas capazes de determinar enchentes na Região Metropolitana;

2. Queda da cota na tomada d'água da Usina Henry Borden em níveis insuficientes para assegurar o fornecimento de energia eléctrica em situações emergenciais;

3. Formação de espumas surfactantes no rio Tietê, a jusante da barragem de Edgard de Souza, que venham a extravasar o espelho d'água;

4. Formação de bloom de algas nos corpos hídricos da Região Metropolitana de São Paulo e no Médio Tietê, comprometendo sua qualidade para fins de abastecimento público;

5. Ocorrência de intrusão salina ou de queda de nível na bacia do rio Cubatão, de modo que comprometa o funcionamento das indústrias que dela captam água para o processo produtivo. (Resolução Conjunta SMA-SES-3). 
Posteriormente, por meio de sentença judicial de 12 de abril de 1994, proferida no curso da Ação Civil Pública, movida pelo Ministério Público do Estado de São Paulo, ficou suspensa a aplicação desse último item das condições emergenciais citadas.

Após três anos de aplicação da Resolução Conjunta SMA-SES-3, constatouse a conveniência de adequação operacional dos procedimentos previstos, mediante o estabelecimento de critérios objetivos para os casos excepcionais de bombeamento por ela admitidos, sem prejuízo de seu acompanhamento.

Assim, foi editada a Resolução SEE/SMA/SRHSO no 1, de 13 de março de 1996, por meio da qual os órgãos responsáveis pela operação do Sistema Hídrico da Bacia do Alto Tietê e das bacias a ela interligadas ficam autorizados a realizar o bombeamento das águas do rio Pinheiros para a represa Billings quando surgirem situações de emergência relacionadas à ocorrência de enchentes, ou seja: previsão de vazão do rio Tietê, no ponto de sua confluência com o rio Pinheiros acima de $160 \mathrm{~m}^{3} / \mathrm{s}$, sobrelevação superior a $30 \mathrm{~cm}$ do nível d'água na confluência do rio Tietê com o rio Pinheiros.

Nas demais situações emergenciais foram mantidos os mesmos procedimentos estabelecidos na resolução anterior. Essa regra é efetuada até hoje.

\begin{abstract}
Atualmente, o déficit crítico de fontes de água para o abastecimento da Região Metropolitana de São Paulo, bem como a impossibilidade da realização de obras (dado o alto custo social, financeiro e ambiental) para se trazer água de outras bacias, fazem da Billings a alternativa lógica para abastecimento. Assim, a represa acumula todas as vantagens táticas e locacionais de um reservatório de grande porte, situado próximo e à montante da mancha urbana da RMSP. Destaca-se que esse reservatório tem integrado o sistema produtor da SABESP através da captação de água realizada no braço do rio Grande, suprindo a região do $A B C$ com 3,9 $\mathrm{m}^{3} / \mathrm{s}$. (CETESB: 1997).
\end{abstract}

Baseado nesse parecer, os técnicos e o próprio governo, que defendem o uso da represa Billings para o uso da população, apresentam o seguinte argumento: "A constatação desse déficit e das potencialidades ainda não exploradas da Billings 
implica adotar, como política de governo, que o abastecimento deve ter prioridade sobre todos os outros possíveis usos da represa".

Reconhece as dificuldades de eliminar a médio prazo o bombeamento para o controle de cheias, na geração de um mínimo de energia em Henry Borden entendida como tática para a operação do sistema energético.

Além disso, existe um conjunto de, pelo menos, três problemas interligados, que dificultam a utilização da Billings, principalmente para o abastecimento público:

1ํ A demanda por água para uso industrial na Baixada e os efeitos da má qualidade da água do Tietê nos municípios do Médio Tietê;

2ㅇ A necessidade de controlar o uso do solo dos municípios situados a montante das áreas de mananciais da metrópole, ainda com capacidade de reter água nas calhas dos rios principais, a proteção do manancial Billings dos efeitos negativos da bacia;

3 o O controle de inundações menos dependente do sistema de bombeamento das cheias para a Billings, que é insuficiente como solução, buscando ainda minimizar seus efeitos negativos sobre a qualidade da água do reservatório.

Como foi visto, alguns dos principais problemas que limitam a utilização do reservatório Billings para o abastecimento público é causado principalmente pelos efeitos da urbanização sem planejamento prévio, o que torna cada vez mais estratégicas as ações governamentais, no sentido da criação e elaboração de políticas públicas em relação ao uso do solo, pois, determinadas políticas e normas mal elaboradas ou mal aplicadas, podem colocar a perder todo um esforço que tem sido feito para a preservação dos mananciais. Como veremos, a política de habitação dos anos 1970, com a construção da Cohab Brigadeiro Faria Lima no Grajaú, pois já vinha ocorrendo debates no meio técnico sobre a poluição desse reservatório desde os anos 1950-1960, e na década de 1970 pelo próprio Estado, através da Prefeitura do município de São Paulo, incentiva a ocupação sem urbanização, sem quaisquer condições de infraestrutura em uma grande área rural, nas bordas da represa conforme será analisado no capítulo 2 . 


\section{Capítulo 2: Urbanização, políticas habitacionais e formação da Península do Ribeirão Cocaia}

\subsection{A construção da Cohab Brigadeiro Faria Lima - Bororé}

O Conjunto Habitacional Brigadeiro Faria Lima, também conhecido como Cohab Bororé, foi criado durante a década de 1970, mais especificamente no período entre 1973-1975. Esse conjunto mantem as principais características das Cohabs entregues neste período, que são a enorme distância em relação aos centros das cidades e das áreas que concentram os serviços urbanos, e o fato deles terem sido instalados muitas vezes em áreas ainda rurais.

A Cohab Brigadeiro Faria Lima possui uma especificidade a mais, um agravante ainda maior, que foi a instalação dentro de uma área definida como área de proteção de mananciais (APM), na subprefeitura da Capela do Socorro, no distrito do Grajaú, em São Paulo.

A obra de construção do conjunto habitacional Brigadeiro Faria Lima começou pouco antes da promulgação das leis estaduais de proteção aos mananciais (Leis no 898/75 e no 1.172/76), por esse motivo, não é possível dizer que a construção desses prédios tenha sido ilegal, mas é certo que a Companhia ignorou a existência dessas propostas. As leis que regulam a proteção aos mananciais foram promulgadas entre os anos de 1975-1976, pouco tempo depois da construção desse conjunto. No entanto, antes disso a questão da discussão e implementação das leis já vinham sendo realizadas pelo meio técnico no bojo dos planos de desenvolvimento metropolitano, como foi o caso do Plano de Desenvolvimento Metropolitano Integrado (PMDI) de 1970. À luz desses acontecimentos, é certo afirmar que as políticas públicas de governo no estado São Paulo eram contraditórias, opondo o Governo do Estado e a Prefeitura do município de São Paulo que, através da Cohab, agiu de maneira equivocada em relação à localização e à instalação do Conjunto habitacional Faria Lima.

A região Sul de São Paulo, apesar de ser considerada Área de Proteção dos Mananciais, não fugiu da mesma política de exclusão territorial que caracterizou a formação das regiões periféricas da cidade. Contraditoriamente, em 1976 implantou-se, no Grajaú, um conjunto habitacional da Cohab chamado Bororé, que levou mais de 13 mil 
moradores para a área recém-definida como área de mananciais pelo poder público. Lembrando que a consolidação de um conjunto habitacional obrigou o desenvolvimento de toda uma infraestrutura, repetindo os clássicos processos de formação das periferias distantes que contraditaram os objetivos de "preservação" e "congelamento" orientados pela legislação dos mananciais. (POLLI, 2010, p. 94).

Desse modo, o Banco Nacional da Habitação (BNH), através das Cohabs, acabou tendo um papel nefasto no processo de estruturação/desestruturação das metrópoles brasileiras:

$\mathrm{O}$ BNH é um desarticulador da cidade como um todo. Visto a priori, a escolha das terras para edificação dos conjuntos parece ter obedecido a um critério fundamental, o distanciamento do centro figurando em todos os casos como um dado obrigatório. O resultado, como é em São Paulo, é o reforço de um modelo de expansão radial, deixando vazios no interstício e abrindo campo a especulação fundiária. A localização periférica dos conjuntos residenciais serve como justificativa à instalação de serviços públicos, ou em todo o caso, à sua demanda. É assim que se criaram nas cidades as infraestruturas a que Manuel Leme chama de "extensores" urbanos, como a adução de água, os esgotos a eletricidade, o calçamento que, ao mesmo tempo revalorizam diferencialmente os terrenos, impõem um crescimento maior à superfície, urbana e, mediante o papel da especulação, asseguram a permanência desses vazios. Como estes ficam à espera de novas valorizações, as extensões urbanas reclamadas pela pressão da demanda vão, mais uma vez, dar-se em áreas periféricas. O mecanismo de crescimento torna-se, assim, um alimentador da especulação, a inversão pública contribuindo para acelerar o processo. Os pobres são as grandes vítimas, praticamente indefesas, desse processo perverso. (SANTOS, 1990, p. 31).

Segundo Cleide, presidente da associação de moradores, do BNH - Cohab Brigadeiro Faria Lima:

Grande parte do conjunto habitacional foi entregue em 28 de agosto de 1975, e não havia luz nas ruas, água nas torneiras, portanto não havia água encanada, a água era trazida por caminhão pipa, ou os moradores iam buscar em uma caixa-d'água que existe dentro do conjunto habitacional e foi utilizada para fornecer água aos trabalhadores para a realização da própria construção das unidades habitacionais da Cohab, neste período, mesmo a luz na época da entrega das casas, não chegou 
todas as residências isso levou mais de um ano para o problema resolvido, o que só ocorreu em 1976 com a entrega de um enorme transformador.

Esse episódio demostra o pouco caso das autoridades da época em relação ao bem-estar dos trabalhadores que ali foram morar.

Figura 13. Veículo de abastecimento de água na Cohab Bororé

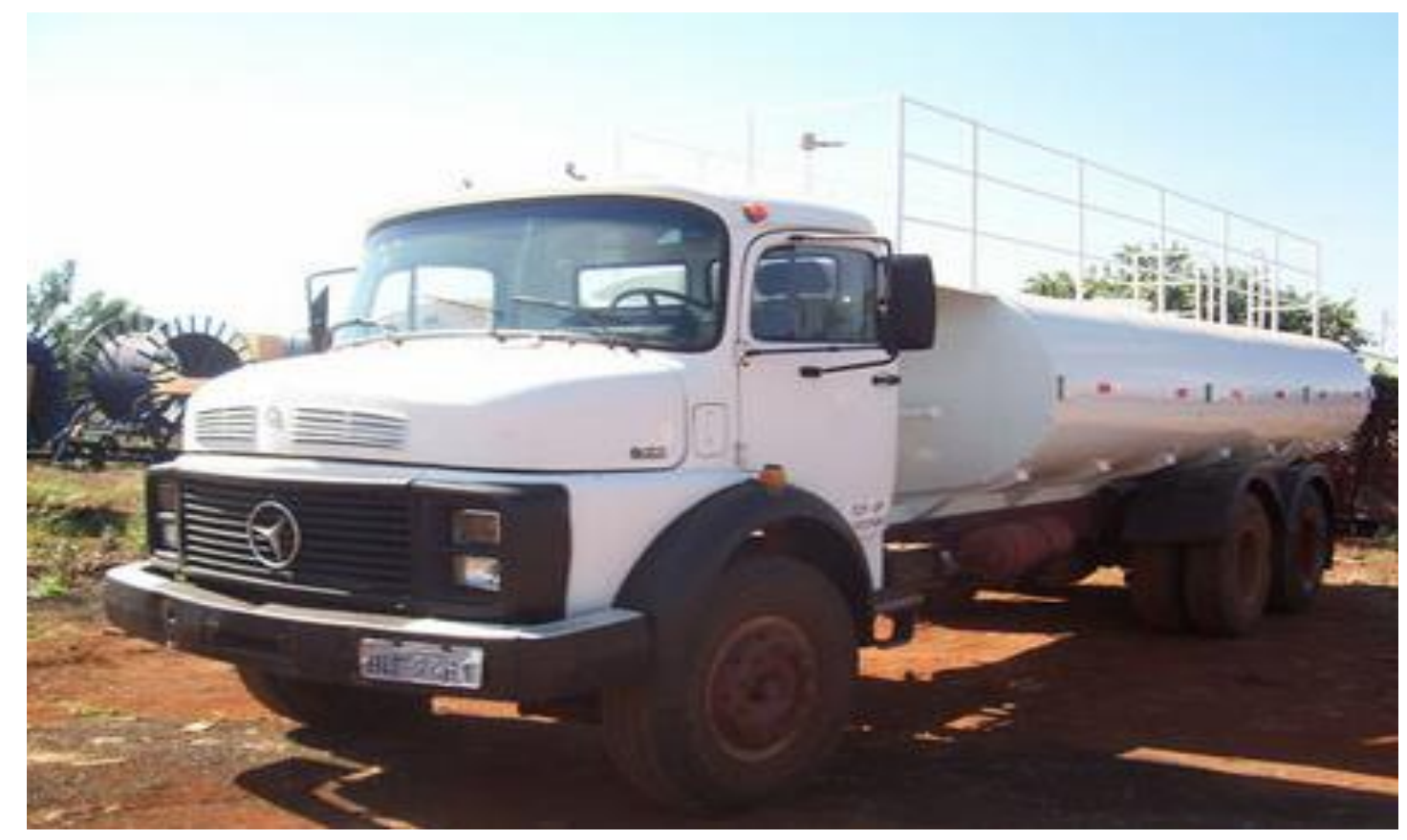

Veículo de abastecimento utilizado para levar água potável aos moradores da Cohab Brigadeiro Faria Lima, em 1975.

Segundo Maria Vilani, também moradora,

neste período dos anos 70 havia a carência de tudo que se possa imaginar: água, saneamento básico, asfalto, a questão da luz e da água que não chegava em todas as residências, transporte muito precário e eram pouquíssimos ônibus, Grajaú não tinha emprego, parecia um bairro dormitório, as pessoas iam trabalhar e só vinham para dormir e o lazer era a televisão.

Mas, ao analisar esse caos, percebemos que, além dessas carências por necessidades básicas, havia uma situação ainda mais complicada, pois não faltavam apenas os serviços básicos, como descrito por Kowarick, em Espoliação Urbana (2009), mas havia também uma espoliação ambiental. Os novos moradores foram levados para a região sem terem sido informados quanto à situação 
ambiental. Não sabiam que a área era dentro da região de mananciais e que estava a ponto de se tornar um local protegido por uma legislação que estava em discussão e cuja implantação desse conjunto de leis era iminente. Do mesmo modo, não foram informados sobre a grande fragilidade ambiental da área, e que seria proibida a instalação de quaisquer obras de melhorias, uma vez que a lei coibiria o adensamento populacional dessa área. A falta de informação adequada, dificultava a população pobre e espoliada de tomar a melhor decisão envolvendo sua moradia.

Dessa maneira, além das dificuldades comuns encontradas na estruturação dessas novas periferias em áreas rurais dos anos 1970, ainda havia este grande agravante, que era o fato de, mesmo com luta, os moradores não poderem conseguir efetivar as conquistas sociais para a região, pois essas conquistas eram inviabilizadas do ponto de vista legal pelas Leis no 898/75 e nํㅜ 1.172/76.

Diferente da maioria das Cohabs, a instalação desse conjunto habitacional representou um conflito de interesses entre o governo do Estado, que propôs as leis de preservação dos mananciais, e os da prefeitura do Município de São Paulo, que, por meio da política municipal de habitação, criou um enorme vetor de ocupação residencial em uma área que viria a ser restrita a esse tipo de uso do solo, ou seja, a instalação da Cohab Faria Lima potencializou a ocupação da área de proteção aos mananciais mesmo depois de promulgadas as leis que regulamentaram o uso e ocupação do solo nas áreas de mananciais. Por isso, é possível concluir que essa população teria mais problemas que outras, já que, teria dificuldade de acesso a direitos sociais urbanos básicos e a um ambiente saudável, pois a lei proibia a instalação de equipamentos públicos e de infraestrutura, incluindo a instalação de esgoto nesses locais.

Diante da questão provocada pela Cohab, o então diretor de recursos naturais da Empresa Paulista de Planejamento Metropolitano S.A (Emplasa), Sadalla Domingos, pronunciou-se anos mais tarde sobre o assunto, referindo-se à atuação da Cohab: 
Ela, ao programar conjuntos habitacionais na zona dos mananciais, age com uma visão estreita, só considerando o custo da terra, não se preocupando com outros fatores (Jornal da Tarde, 19 out. 1983).

Poderíamos falar que essa população sofreu não apenas uma espoliação urbana, mas um processo ainda maior que foi uma espoliação urbano-ambiental.

Desde então a vida desses moradores foi marcada por um constante processo de lutas, que atravessaram as décadas seguintes. Com momentos de conquistas por parte da população local.

Segundo Cleide:

Os anos 80 foram marcados no bairro Grajaú por uma verdadeira revolução, Dona Carmélia, a então líder da Associação Amigos Bairro da Cohab Faria Lima, conseguiu organizar a associação dos moradores de bairro, ela trouxe a feira, porque o bairro não tinha uma feira, conseguiu mais uma linha de ônibus, porque o bairro só tinha uma linha inaugurada em 1980.

Figura 14. Linha de ônibus Grajaú

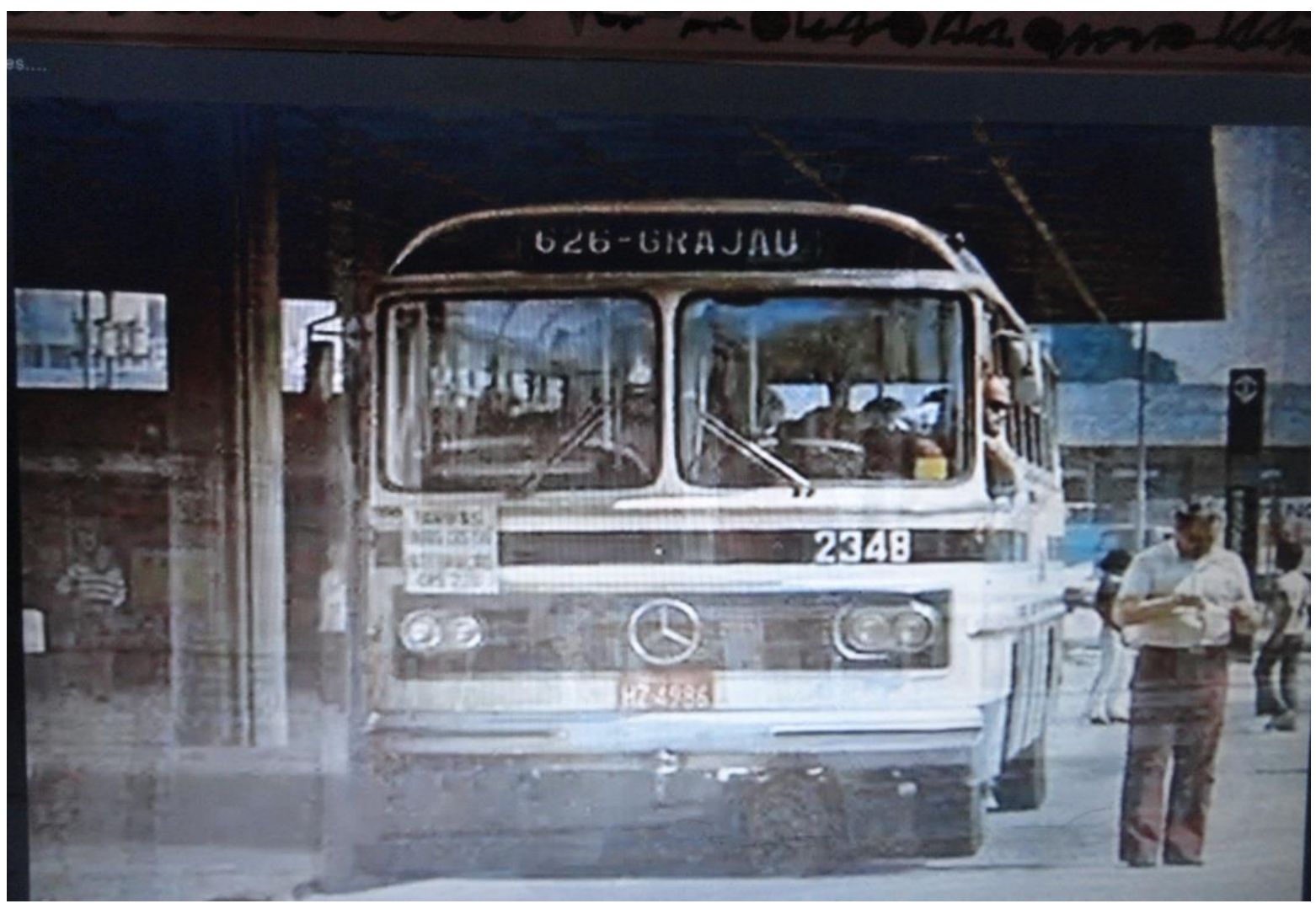

Ônibus da antiga Companhia Metropolitana de Transporte Coletivo (CMTC) em linha que atendia o Grajaú. 
Uma das conquistas de Dona Carmélia foi o fechamento da rua São José do Rio Preto aos finais de semana para que as crianças pudessem brincar. Essa rua ficou conhecida como "rua de lazer".

Figura 15. Rua São José do Rio Preto, no Grajaú

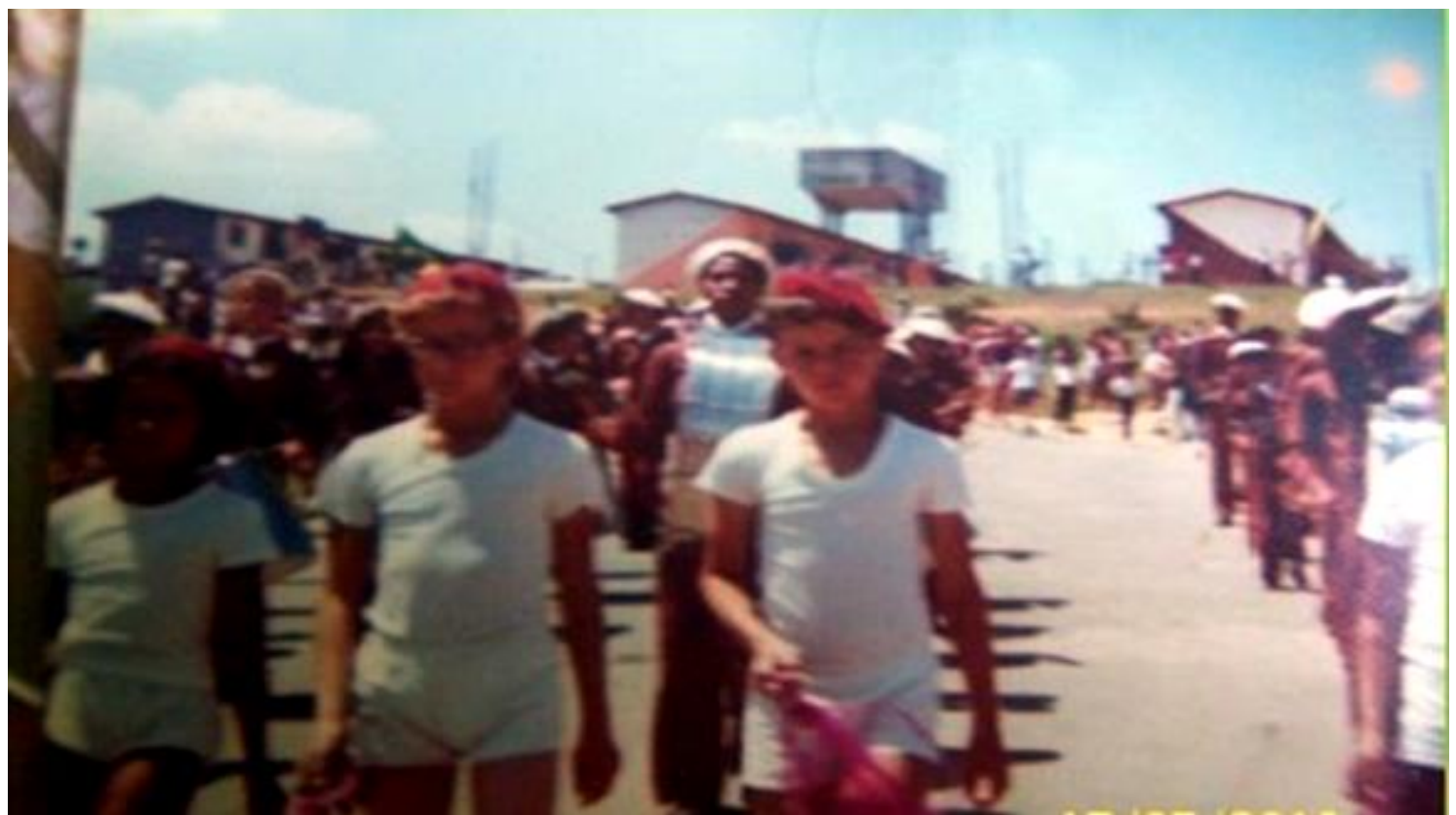

Rua São José do Rio Preto, no bairro do Grajaú, fechada nos fins de semana para a prática de lazer, na década de 1980. Fonte: Portfólio da Associação dos Moradores do Grajaú.

Essa é uma das primeiras formas de subversão que aconteceu no local que era desenhado com a preocupação apenas de moradia e que empobrecia todas as formas de uso do urbano. Assim, a rua que servia apenas para circulação passa a ter recreação: é a realização do lazer subvertendo o uso esperado do espaço, tornando-o mais público e mais democrático.

Os mercados chegaram bem depois, entre 1988-1989. Anteriormente a isso, o único comerciante que tinha era o senhor Marçal, um japonês que não falava português, mas conseguia entender o que a gente tava pedindo, e o pessoal comprava nele, ou havia o caminhão da Cobal, que vinha uma vez por mês, mas as filas eram enormes, e só podia pegar um saco de arroz, um saco de feijão quando entrava dentro do caminhão, porque os alimentos tinham que dar para todo mundo comprar. (Entrevista com Cleide Presidente da Associação de Moradores do Grajaú). 
Segundo o portfólio da Associação de moradores do Grajaú:

Quando era dia do caminhão vir, todas as crianças saíam correndo gritando: "Mãe, o caminhão da Cobal chegou!". Ele sempre parava em frente do campo de futebol. A fila era enorme; isso ocorreu de 1977 até os anos 1980 .

Figura 16. Caminhão da Cobal

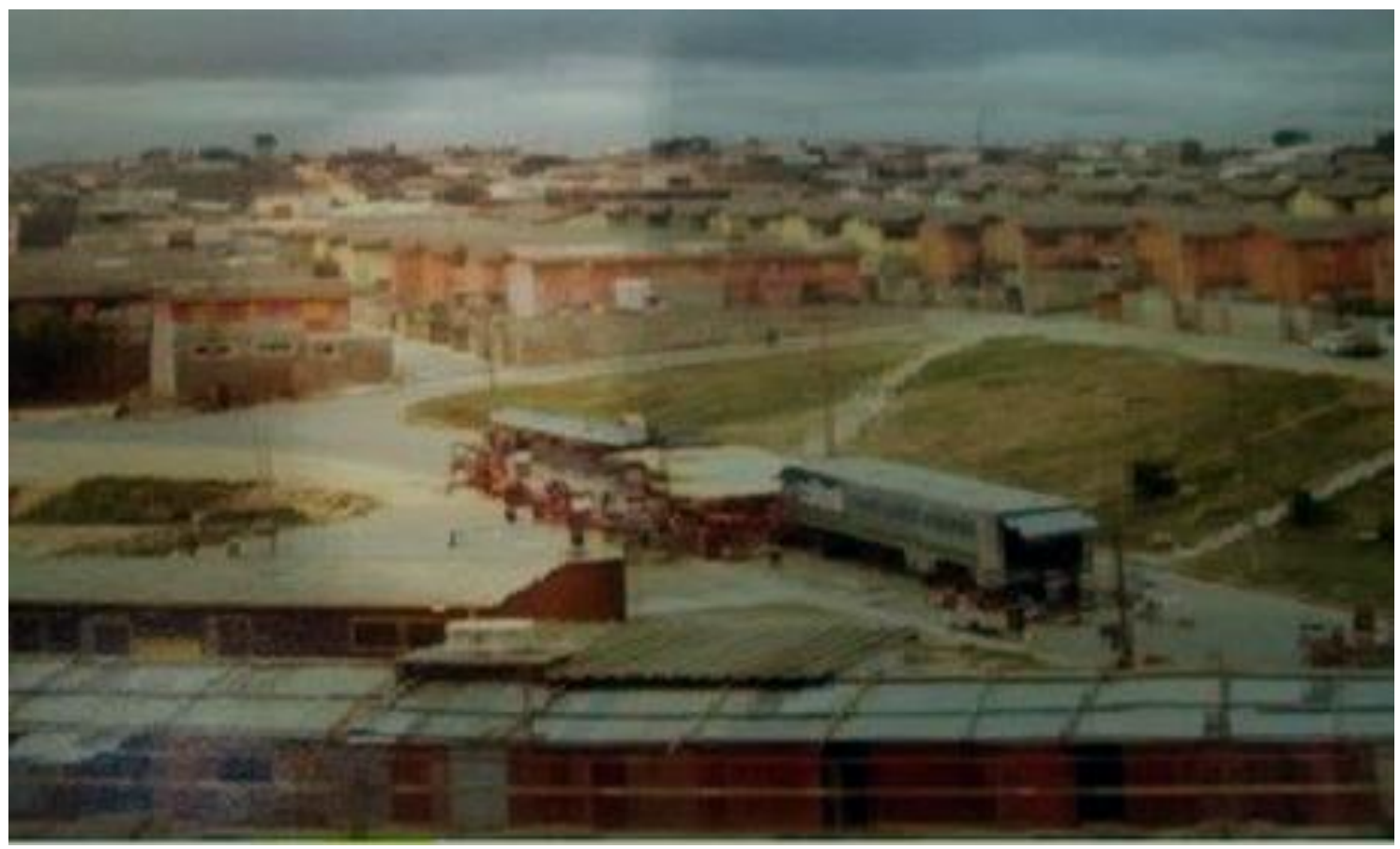

Caminhão da Cobal vende alimentos aos moradores do Grajaú, em 1977. Fonte: Portfólio da Associação de moradores do Grajaú.

Houve também a construção das escolas estaduais Samuel Wainer, João Goulart, nos anos 1980, e, na gestão do governador André Franco Montoro (19831987), a instalação da "famosa vaca mecânica", que oferecia leite gratuitamente à população. Eram entregues aos moradores garrafas próprias que vinham com emblema do Estado e cada residência tinha direito a três litros de leite, desde que fossem retirar até as 6 horas da manhã. A entrega era feita pelo Sr. Nicola na rua São Caetano do Sul, 656. (Portfólio da Associação de moradores do Grajaú, p. 13).

Os anos 1980 marcaram o início de alguma presença estatal no bairro do Grajaú, alguns programas sociais, como o da distribuição de leite especialmente na área da Cohab Faria Lima, entretanto muito do que se conquistou deveu-se à luta dos moradores da associação de moradores do Grajaú e, em especial, a Dona Carmélia, conforme relata o portfólio da associação: 
Conseguimos muitas vitórias através da Tia Carmélia, assim chamada pelas crianças, uma delas é essa empresa de ônibus a Bola Branca, então ao invés de uma linha Anhangabaú de ônibus passamos a ter mais quatro: Vila Mariana, Jabaquara, Butantã e Hospital das Clínicas, e até os dias de hoje continuamos com três linhas: Praça da Sé, Jabaquara e Butantã.

Figura 17. Ônibus da Viação Bola Branca, no Grajaú

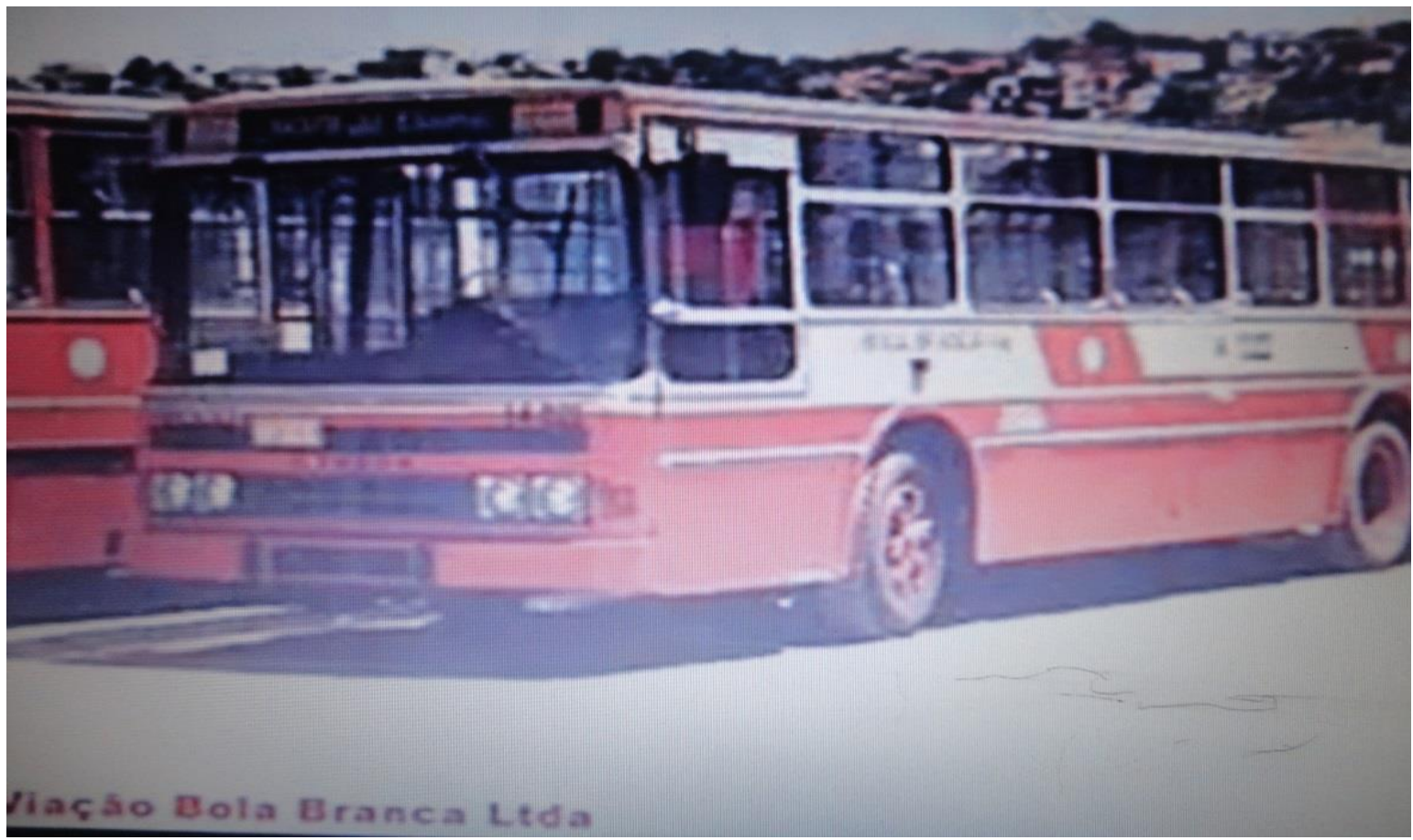

Fonte: Portfólio da Associação de Moradores do Grajaú, década de 1980.

Segundo Cleide:

No final dos anos 80 e principalmente no início dos nos 90 , foram os melhores anos do bairro com a construção do posto de saúde, a chegada das padarias e dos grandes mercados, mais linhas de ônibus.

Isso pode parecer contraditório em função do agravamento da questão econômica que atravessara os anos 1980 e que piorava especialmente no início dos anos 1990, mas cabe lembrar que a luta por melhorias por parte dos moradores da Cohab-Brigadeiro Faria Lima já vinha de mais de uma década e meia, e esta parte do distrito do Grajaú, nesse momento, já apresentava características de uma periferia consolidada, a dimensão de precariedade já havia atingido pontos ainda mais distantes do que o subdistrito do Grajaú, nesse caso na Península do Ribeirão Cocaia, que eram os bairros Parque Residencial Cocaia e, principalmente, o bairro Cantinho do Céu. 
Figura 18. Prédios da Cohab Grajaú

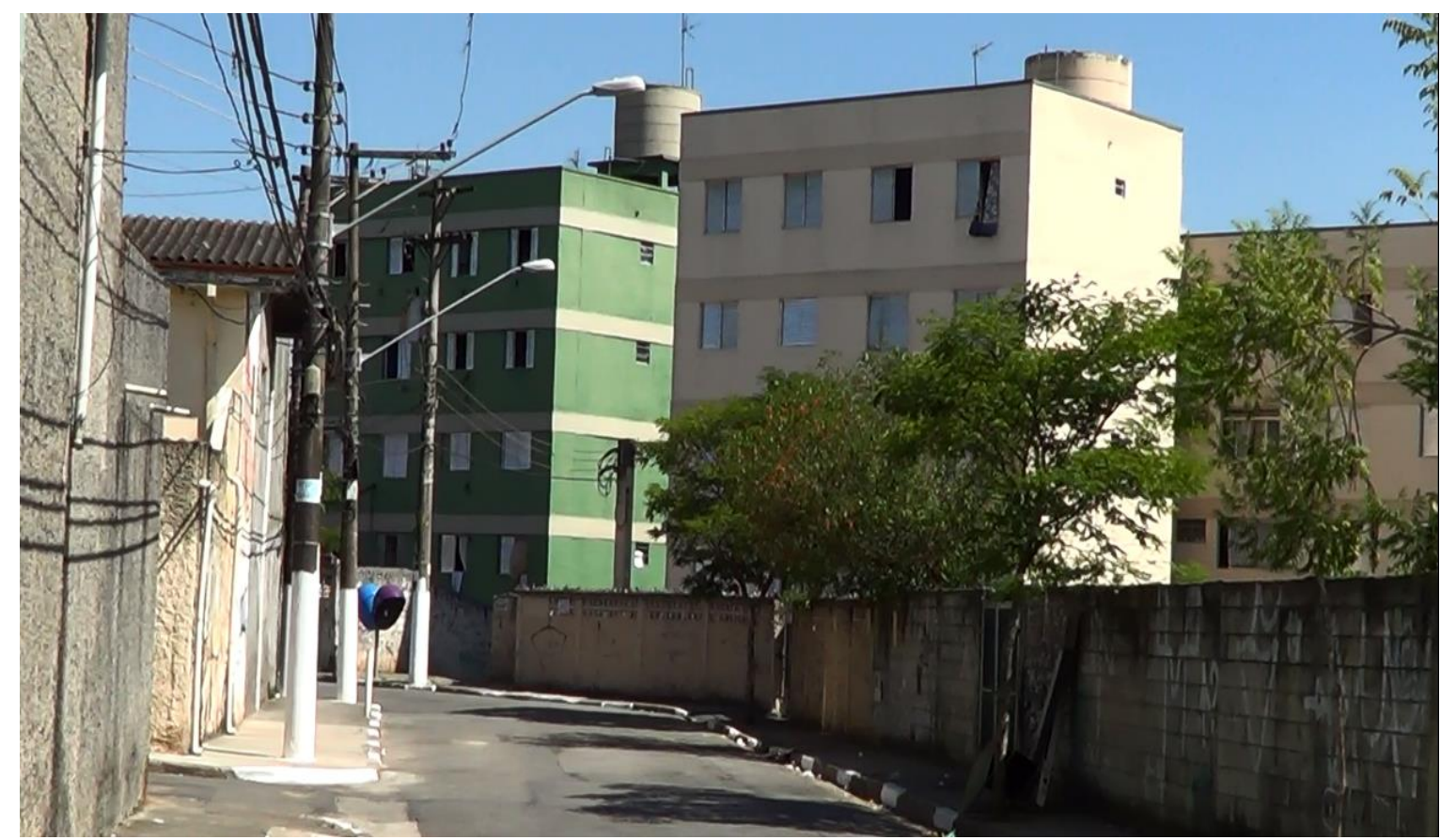

Vista atual dos prédios da Cohab Grajaú, 28 de março de 2016. Foto do autor.

\subsection{A formação dos bairros Parque Residencial Cocaia e Cantinho do Céu}

\subsubsection{Parque Residencial Cocaia}

A formação do Parque Residencial Cocaia data de 1981, quando a imobiliária Federal São Paulo "inicia a venda de lotes na área chamada de Morro da Macumba, do lado esquerdo do Jardim Eliana e estrada Canal de Cocaia, em princípio com o nome de loteamento Cocaia II, isso porque a mesma empresa já havia criado um outro loteamento com o mesmo nome Cocaia I (documento da Associação dos Moradores do Parque Residencial Cocaia Independente).

O loteamento já estava sendo aberto concomitante à construção da CohabFaria Lima. Já se notava o arruamento, deixando vários terrenos vazios entre os dois empreendimentos, o Estatal, no caso a Cohab, e o privado da Federal São Paulo, mostrando a clara tendência da especulação imobiliária que se forma nessa área de manancial, ainda que seja proibido o seu adensamento por força da lei.

Devido à precariedade e carência do lugar, em 19 de março de 1982 o senhor Cláudio José Canõn, mais conhecido como Sr. Canhão, reúne-se com outros 
moradores e, após várias reuniões, fundam a Associação de Moradores Amigos de Bairro.

\begin{abstract}
Sentindo os problemas de falta de água, de falta de luz, asfalto, transporte, saúde, educação, creches, entre outros, iniciamos várias reuniões para fundar a associação amigos de bairro. Entrevista com Sr. Claudio José Cañon.
\end{abstract}

No dia 27 de março de 1983, com a participação de 117 moradores foi aprovado o estatuto e escolhido o nome do bairro, o qual passou se chamar Parque Residencial Cocaia Independente, o mesmo nome da sociedade amigos de bairro.

Em 21 de abril de 1983, com a participação de mais de 200 moradores, é eleita a primeira diretoria da associação de moradores com o Sr. Rubens Moura como presidente, o qual desistiu do cargo em 16 de julho de 1983, assumindo o vice-presidente eleito em abril, o Sr. Cláudio Canhão. A partir de então, inicia-se o processo de luta dos moradores da associação para as melhorias urbanas no bairro. No dia 25 de agosto de 1983, acontece a primeira reunião dos moradores com as autoridades do Estado e da Prefeitura para reivindicar, água, transportes coleta de lixo, luz de mercúrio.

É interessante notar que os empreendedores imobiliários apenas fazem o loteamento e abrem as ruas, tratando de vender os lotes o mais rápido possível por meio de imobiliárias que abrem de manhã, vendem à tarde e desaparecem à noite, ou seja, em geral, quando é hora de vender esses terrenos, os negócios são feitos o mais rápido possível, a toque de caixa, após esse procedimento as imobiliárias juntamente com seus respectivos responsáveis acabam desaparecendo logo depois.

Cabe lembrar que isso aconteceu nos anos 1980 em pleno vigor da recémcriada lei federal de parcelamento e uso do solo urbano, mais conhecida como Lei Lehmann no 6.766, de 19 de dezembro de 1979. Esta lei é a que dispõe sobre o parcelamento do solo e dá outras providências à questão. 
No seu capítulo I, a lei estabelece claramente no seu Art. 2ㅇ․

O parcelamento do solo urbano poderá ser feito mediante loteamento ou desmembramento, observadas as disposições desta Lei e as das legislações estaduais e municipais pertinentes.

Continua no seu Capítulo VIII das disposições gerais no Art. 37.

"É vedado vender ou prometer vender parcela de loteamento ou desmembramento não registrado", e no capítulo IX das disposições penais no seu artigo 50 criminaliza uma série de transgressões impondo penas aos seus infratores.

No seu artigo 50, estão previstas as penalidades aos loteadores. Constitui crime contra a Administração Pública.

I - dar início, de qualquer modo, ou efetuar loteamento ou desmembramento do solo para fins urbanos, sem autorização do órgão público competente, ou em desacordo com as disposições desta Lei ou das normas pertinentes do Distrito Federal, Estados e Municípios;

II - dar início, de qualquer modo, ou efetuar loteamento ou desmembramento do solo para fins urbanos sem observância das determinações constantes do ato administrativo de licença;

III - fazer ou veicular em proposta, contrato, prospecto ou comunicação ao público ou a interessados, afirmação falsa sobre a legalidade de loteamento ou desmembramento do solo para fins urbanos, ou ocultar fraudulentamente fato a ele relativo.

Pena: Reclusão de 1 (um) a 4 (quatro) anos, e multa de 5 (cinco) a 50 (cinquenta) vezes o maior salário mínimo vigente no País.

É muito interessante analisar essa lei, uma vez que as coisas continuaram a correr à revelia mesmo com a elaboração dela, por exemplo, no $1^{\circ}$ artigo quando fala que loteamentos devem ser feitos respeitando as leis estaduais e municipais, logo se vê o desrespeito às Leis no 898/75 e no 1.172/76, precisamente as leis de proteção aos mananciais, uma vez que elas são da década de 1970 e os loteamentos continuavam acontecendo normalmente como se a lei não existisse. 
As penas foram estipuladas, entre um a quatro anos de reclusão, além de multas, mas na área de estudo nunca se soube de um caso de algum loteador que tenha ido parar na cadeia por vender loteamentos irregulares, sem registro nos órgãos oficiais.

Como os loteadores apenas tratavam de vender os terrenos e desapareciam logo em seguida, o rescaldo desse processo ficava a cargo dos moradores. Esses tinham que se mobilizar e correr atrás de melhorias para 0 bairro, processo que pode levar até décadas como ocorrido em outra área de mananciais, o Parque Boulogne, na Bacia de Guarapiranga, onde os loteamentos foram vendidos a partir de 1978 em um processo relativamente semelhante ao do Parque Residencial Cocaia, mas o asfalto só foi chegar vinte anos depois, em 1998, após muita luta dos moradores, que iam a prefeitura, e ouviam que a rua já tinha sido asfaltada. Provavelmente, isso significa obras fantasmas que tiveram desvio de verba.

Por meio da mobilização dos moradores, o Parque Residencial Cocaia conquistou, na década de 1980, melhorias de infraestrutura, como o cascalhento e regularização de ruas, ligação de água encanada, a iluminação de mercúrio. Com a visita do prefeito Mário Covas (1983-1985) no bairro, também foi implantada a primeira linha de ônibus servida pela Viação Bola Branca, mas que só atendia de manhã e à tarde, com funcionamento até as 20 horas, além de equipamentos públicos para o bairro, como a escola estadual Washington Alves Natel, inaugurada por Franco Montoro em 1986, e a inauguração do posto de saúde.

Cabe observar também algo um pouco diferente do escrito pela literatura, que relata geralmente que esses loteamentos foram abertos com a combinação entre loteadores clandestinos e donos de linhas de ônibus, que abriam as linhas possibilitando que os compradores chegassem ao local onde viriam adquirir seus lotes e estabelecer suas respectivas residências, tanto no caso do bairro Grajaú, quanto no caso do Parque Residencial Cocaia, no subdistrito Grajaú com a implantação da Cohab, e no Parque Residencial Cocaia com a implantação do loteamento pela Federal São Paulo, sequer havia ônibus que levasse os moradores até local onde iriam morar. Os relatos de Vilani, Canõn e Cleide são de que as linhas ficavam entre $1,5 \mathrm{~km}$ a 2,5 km de distância. 
Esses moradores ainda se encontravam em uma situação pior do que a maioria dos trabalhadores que passaram pelo processo de ocupação periférica, uma vez que na maioria dos casos que são descritos pela literatura havia, pelo menos, uma linha de ônibus que servia o local. Entretanto, no Grajaú e no Cocaia, conforme relatam os moradores, eles se viam obrigados, após a compra do terreno, a correr atrás de todas as melhorias que os loteadores deveriam oferecer. Nesse caso, nem com linhas de ônibus as pessoas desses loteamentos eram servidas.

Em 1987, a Associação de moradores do Parque Residencial Cocaia recebe a visita do então prefeito Jânio Quadros, que, de acordo com a ata da Associação de moradores, naquele momento queria processar o Senhor Canhão, por ter feito um panfleto com críticas à administração devido a situação do bairro. Ao chegar e ver a situação de calamidade, autorizou em caráter de urgência asfaltar várias ruas do bairro e a implantação de mais três linhas de ônibus: Jabaquara, Terminal Santo Amaro e Terminal Tietê".

Em 1988, surge loteamento Residencial Cipramar. Em 1989 é fundada a associação de moradores Cipramar-Bororé, com Canhão como presidente. Em 1990, surge o loteamento Bororé (sem área de lazer).

Segundo documento da Associação dos Moradores:

com Paulo Maluf como prefeito de São Paulo entre 1993-1996, foram construídas a escola municipal Frei Damião e a escola municipal de ensino infantil Emei Cipramar, hoje João Candido. Com ele veio também à construção da creche municipal, a implantação do Posto de Polícia, o comércio se multiplicou com muitas lojas e supermercados, entre eles o supermercado Yokoi, atualmente Ricoy, mercadinho do Paraguay, várias farmácias, padarias, isto apenas no Parque Residencial Cocaia, já que os bairros que surgiram ao lado (Recanto Cocaia, Cantinho do Céu, Gaivotas, Parque dos Lagos, Cipramar e Bororé), também aumentaram as moradias e o comércio.

Apesar dos avanços, na implantação de equipamentos sociais para os bairros, em termos mais gerais nas gestões de Paulo Maluf e Celso Pitta (1993-2000) estavam havendo remoções maciças de população de áreas mais centralizadas da cidade, e anistias, inclusive para ocupação de áreas de proteção de mananciais. 
Desfavelar nesse período volta a ser entendido como "remoção da população favelada das áreas nobres da cidade para localidades periféricas". (SILVA, 2003, p. 19).

Uma obra bastante polêmica que ocorreu no bairro nesse período foi a construção da Escola Parque Residencial Cocaia, mais exatamente no Cipramar. Segundo o documento da associação de moradores em 1989, foi encaminhado um pedido para a construção de uma escola no Cipramar, porém "o pedido foi negado pela então prefeita Luiza Erundina, alegando ser uma área de brejo, que não teria condições de construir nada", então ela foi posteriormente construída por Maluf. Canhão disse em entrevista: "Perguntei a ele, por ocasião de uma visita dele ao bairro, se ele poderia construir a escola nesse terreno, e ele disse: 'Canhão, se eu construí pontes em cima do mar, não é esse corregozinho que vai me atrapalhar, pode deixar que eu vou levantar essa escola.' E levantou". É evidente que era necessária a construção da escola, mas Maluf mais uma vez não se preocupou com as leis vigentes sobre o meio ambiente, nem sequer onde iam estudar as crianças daquela comunidade.

Construindo a escola sobre o córrego, e também consequentemente sobre a sua área de várzea, portanto um lugar susceptível a processos de enchentes e durante os períodos mais prolongados de chuva, o então prefeito Paulo Maluf apenas ratificava o seu pouco caso com as questões naturais e sociais, conforme o que foi descrito acima.

\subsubsection{Cantinho do Céu}

O Cantinho do Céu tem origem, segundo Ricardo Sampaio, "numa área de reflorestamento" (BARDA, França. Org., p. 114, 2012).

Ainda segundo Miranda:

eram terras rurais que, em princípio, não deixaram essa característica, mas foram sendo transformadas em chácaras, tipo de parcelamento que foi aproveitando as qualidades "aprazíveis" que os lotes oferecem em contato com a natureza da área, também devido às proximidades com a represa Billings. (MIRANDA, 2002, p. 67). 
Corrobora para esta explicação a entrevista dada pelo presidente da associação de moradores do Cantinho do Céu, senhor Sandro Mambelli, que disse:

Nós viemos para cá em 1967, por ocasião da compra de uma chácara por parte do meu pai, pois a família morava na Rua Mario de Noronha com Doutor Arnaldo, e meu pai preocupado com a violência da cidade naquela época que estava aumentando comprou uma chácara que se chamava laiá, mas como meus pais haviam se conhecido em São Paulo e viajaram para o rio Grande do Sul, antes que eu nascesse e lá no Rio Grande do Sul eles conheceram uma chácara muito bonita, que se chamava Cantinho do Céu, eles resolveram então colocar o nome na chácara que eles compararam, aqui em São Paulo de Chácara Cantinho do Céu.

Apesar dos dados oficiais mostrarem que nesse período entre 1960-1970 verificou-se as maiores taxas de crescimento no distrito do Grajaú de $17,12 \%$, o que começava a indicar que haveria um forte crescimento nesta área, em termos de população absoluta, o distrito passou em 1960 de 8.969 pessoas para 43.664 pessoas em 1970. O incremento de população foi, portanto, de 34.695 habitantes, entretanto, analisando o mapa de População Absoluta, o Grajaú ainda é um dos distritos menos populosos da cidade de São Paulo, no início da década de 1970.

Figura 19. População absoluta dos distritos de São Paulo — 1970

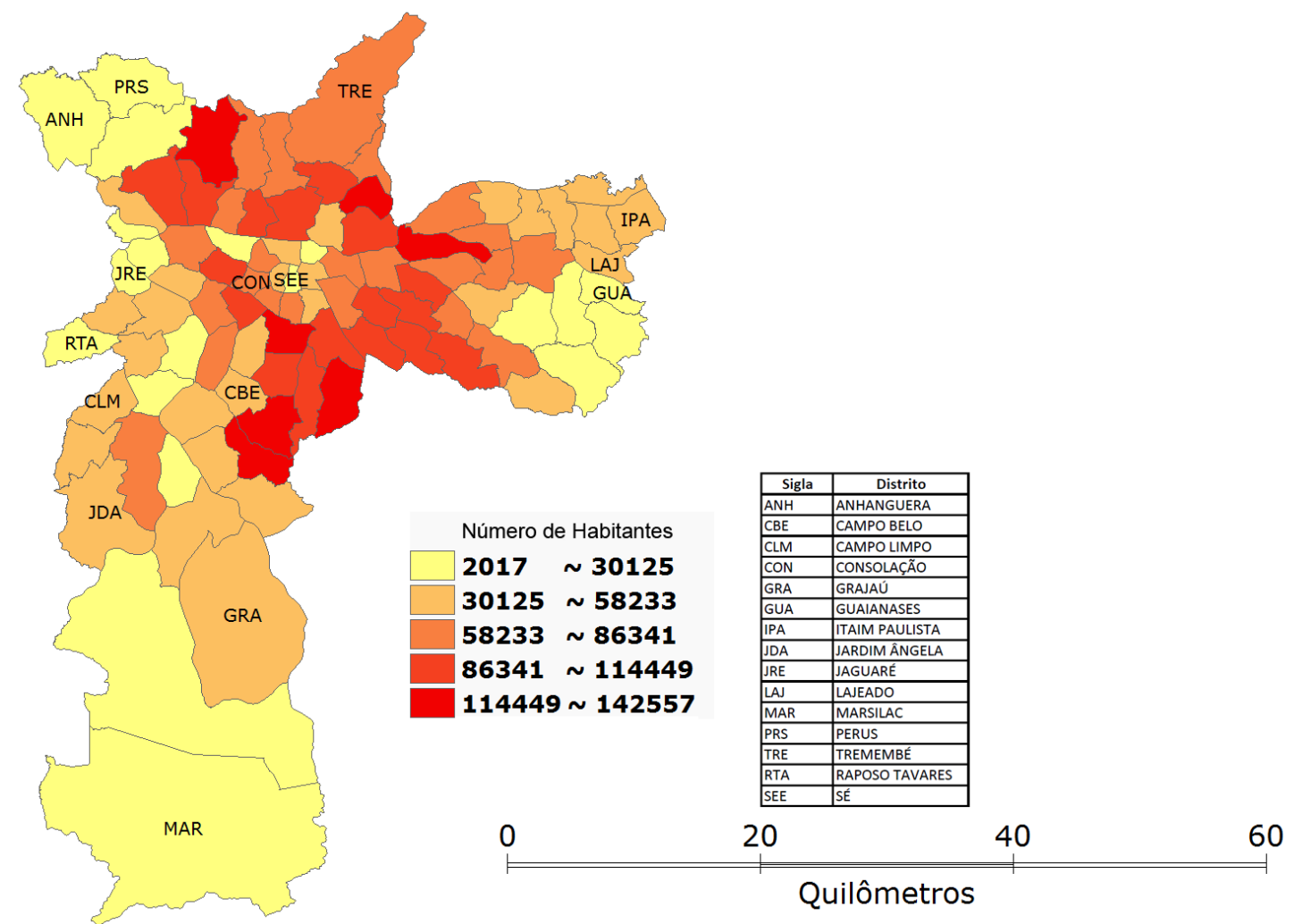

Fonte: Infocidade. Elaborado pelo autor. 
Dessa maneira, apesar de ter sido a maior taxa de crescimento da história do distrito, em números absolutos não foi nessa época final dos anos 1960 que houve o boom de crescimento do distrito, de maneira geral, e do bairro Cantinho do Céu, de modo particular, que ainda tinha características totalmente rurais, conforme é possível perceber por meio da fala de um de seus moradores mais antigos, o senhor Sandro Mamberti.

Em 1969, quando meus pais vieram definitivamente morar aqui, nós plantávamos vários tipos de frutas, tínhamos cavalos, porcos, galinhas, era uma chácara mesmo, e eu pegava uma charretinha, levava alface, almeirão, tomate que a gente plantava e ia vender no Grajaú, e a minha vida de moleque foi essa, era muito gostoso.

A ocupação da área do cantinho do Céu, assim como a do Jardim Gaivotas, dá-se em definitivo a partir de 1988, segundo documento da Associação de Moradores do Parque Residencial Cocaia Independente, logo após o surgimento de loteamento Parque dos Lagos, e Lago Azul que aconteceu em 1987 e intensificou-se nos anos 1990, em um momento de grave crise econômica e grande desemprego no país.

Figura 20. Cantinho do Céu e Represa Billings

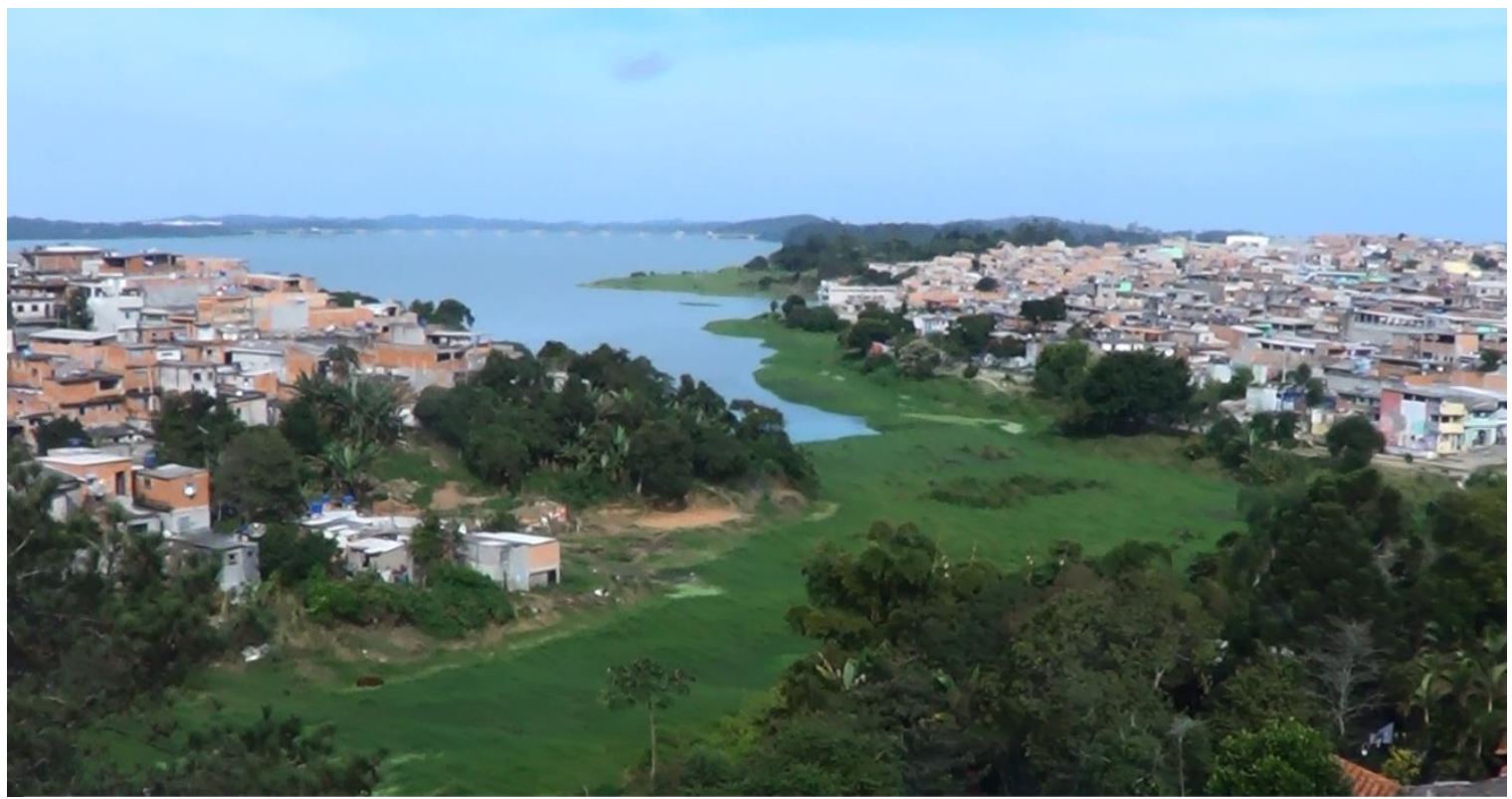

À direita, o Lago Azul e, à esquerda, vista do Cantinho do Céu; no centro da foto, área do reservatório Billings, 30 de maio de 2015. Foto do autor. 
Interessante também são as explicações para o enorme crescimento dos bairros que compõem essa área de mananciais, no caso os bairros da Península do Ribeirão Cocaia e, mais especificamente, o Bairro Cantinho do Céu.

\begin{abstract}
A ocupação irregular é resultado de vários fatores; a legislação que transformou toda área em território protegido com o objetivo de preservação dos mananciais da represa Billings; a não desapropriação das áreas particulares de modo a transformar a região em uma reserva pública à semelhança da área protegida na Cantareira.

Quando você transforma uma região em área de preservação, restringe o uso e a ocupação do solo, limitando seu aproveitamento pelos proprietários; a partir da legislação, os proprietários se veem diante de padrões que anteriormente não estavam em vigor. Também, paralelamente, houve a fase do milagre econômico brasileiro, isto é, a instalação de indústria dos bens de consumo final aqui no país, particularmente, na região metropolitana da cidade de São Paulo. (SAMPAIO, in: BARDA, 2012, p. 114).
\end{abstract}

Durante entrevista, o técnico da Companhia Ambiental do Estado de São Paulo (CETESB), Renato Rosseti, atribui a ocupação das áreas de mananciais:

às pressões demográficas exercidas pela população de baixa renda, às grandes migrações que ocorreram para a cidade de São Paulo, e, mais recentemente, às políticas habitacionais de governo que estimulariam a ocupação da área fornecendo casas dentro das áreas de proteção aos mananciais, como o projeto da prefeitura no Parque dos Búfalos, que pretende colocar habitações populares muito próximos à calha da represa.

Já Miranda apresenta outros fatores que não a migração para explicar o crescimento da área de mananciais e da área de estudo:

o ritmo e as proporções da ocupação da Península do Cocaia como um todo não poderiam ser explicados, apenas pelo crescimento vegetativo da população da área, nem por qualquer movimento migratório espontâneo, interno da Metrópole [...] É no contexto de um quadro político econômico, mais amplo que produz efeitos de longo prazo nos processos de expansão 
urbana, com a redução dramática na oferta de habitação para a população de baixa renda, que se dão as condições gerais para ampliação das futuras formas de acesso à moradia: as invasões e a organização de loteamentos "clandestinos" em áreas de mananciais, a partir da década de 1980. (MIRANDA. 2002, p. 69).

Conforme o exposto acima, a população passou, em um intervalo de apenas trinta anos, de 43.664 pessoas, em 1970, para 333.426 habitantes em 2000.

Dos anos 1970-1990 a situação mais ao norte da Península do Ribeirão Cocaia ainda era pior, quanto mais ao norte mais se deterioravam as condições de vida da população, justamente onde foram implantados os bairros Cantinho do Céu e Parque Residencial Cocaia.

Figura 21. População absoluta dos distritos de São Paulo — 1980

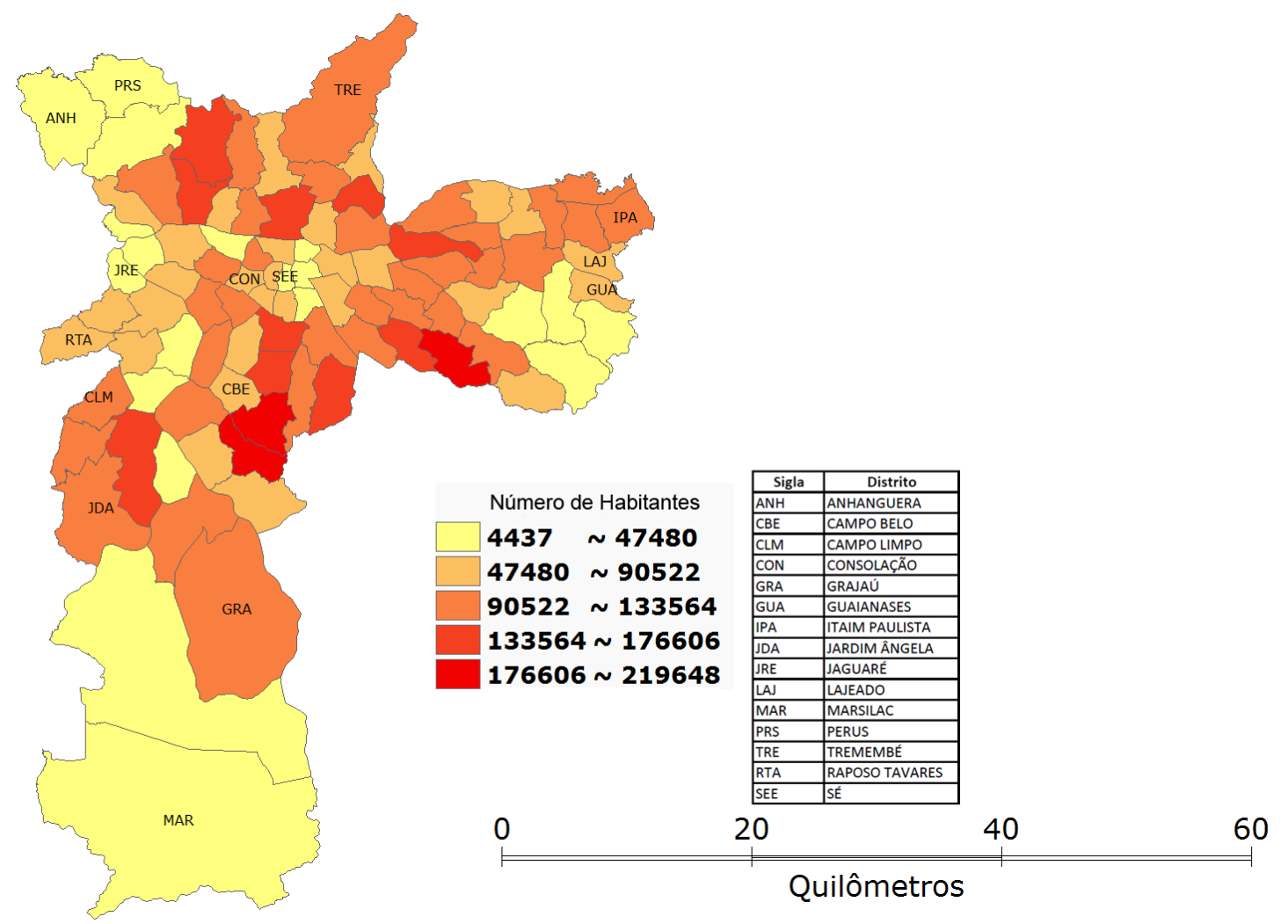

Fonte: Infocidade. Elaborado pelo autor. 
Uma diferença que foi notada em campo é que em ambos bairros possuem ocupações, entretanto as ocupações que formam quase a totalidade das residências atuais do Cantinho do Céu, enquanto no Residencial Cocaia, elas são em um número muito menor. A origem do bairro, Parque Residencial Cocaia, no início dos anos 1980, está ligada ao loteamento irregular promovido pela Imobiliária Federal São Paulo S/A. Já grande parte do Cantinho do Céu enquanto bairro foi formado pelas ocupações em antigas chácaras abandonadas, ao que parece, sem um movimento organizado com este fim.

Isso nos remete ao agravamento das condições da classe trabalhadora ao longo dos anos 1980 e principalmente no fim dessa década e durante os anos 1990. Antes os trabalhadores podiam comprar lotes nos loteamentos clandestinos e irregulares, após esse período a única opção de moradia para boa parte dos trabalhadores passaram a ser as ocupações, pois o salário que ganhavam não thes permitiam mais sequer comprar um lote irregular.

\subsection{Década de 1990: agudização dos problemas urbanos na periferia}

Os anos 1990 não mostraram as maiores taxas de crescimento do distrito do Grajaú, pois as maiores taxas em termos de crescimento foram apresentadas nos anos 1960 , com taxas da ordem de $17,12 \%$, conforme descrito anteriormente.

Para o período 1991-2000, utilizaremos o mapa de população absoluta de 1991 e de 2000 para verificar que é nesse período que ocorre o maior incremento populacional da história do distrito do Grajaú, tendo sua população absoluta passado de 193.754 habitantes para 333.426 habitantes, com um incremento de 139.672 habitantes, o que significa um acréscimo de mais de $70 \%$ no número de habitantes em um intervalo de apenas nove anos. Nesse período, o distrito do Grajaú passou a ser o mais populoso do munícipio de São Paulo dentre as 32 subprefeituras e os 96 distritos que compõem a cidade. 
Figura 22. População absoluta dos distritos de São Paulo — 1991

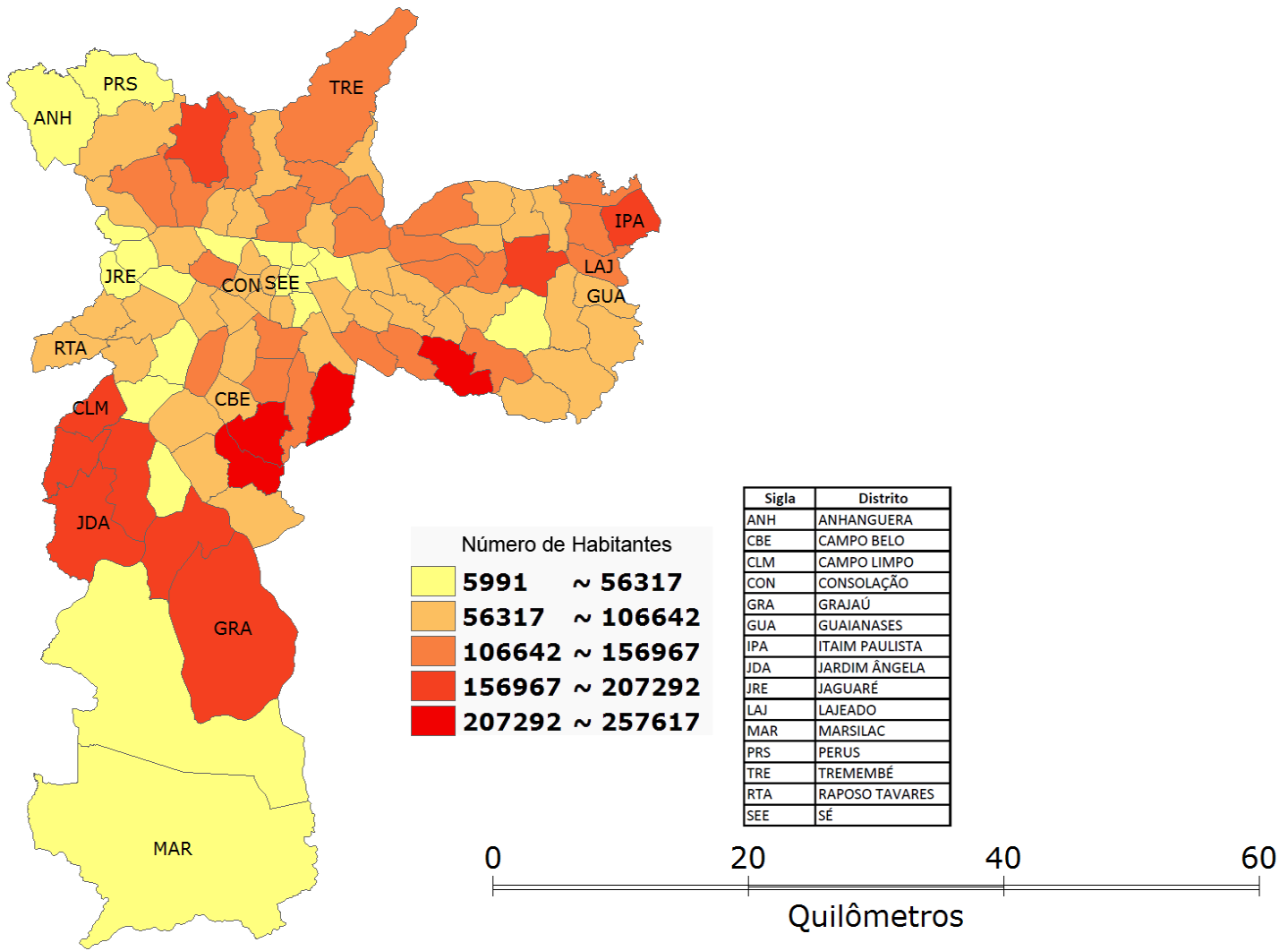

Fonte: Infocidade. Elaborado pelo autor.

Figura 23. População absoluta dos distritos de São Paulo — 2000

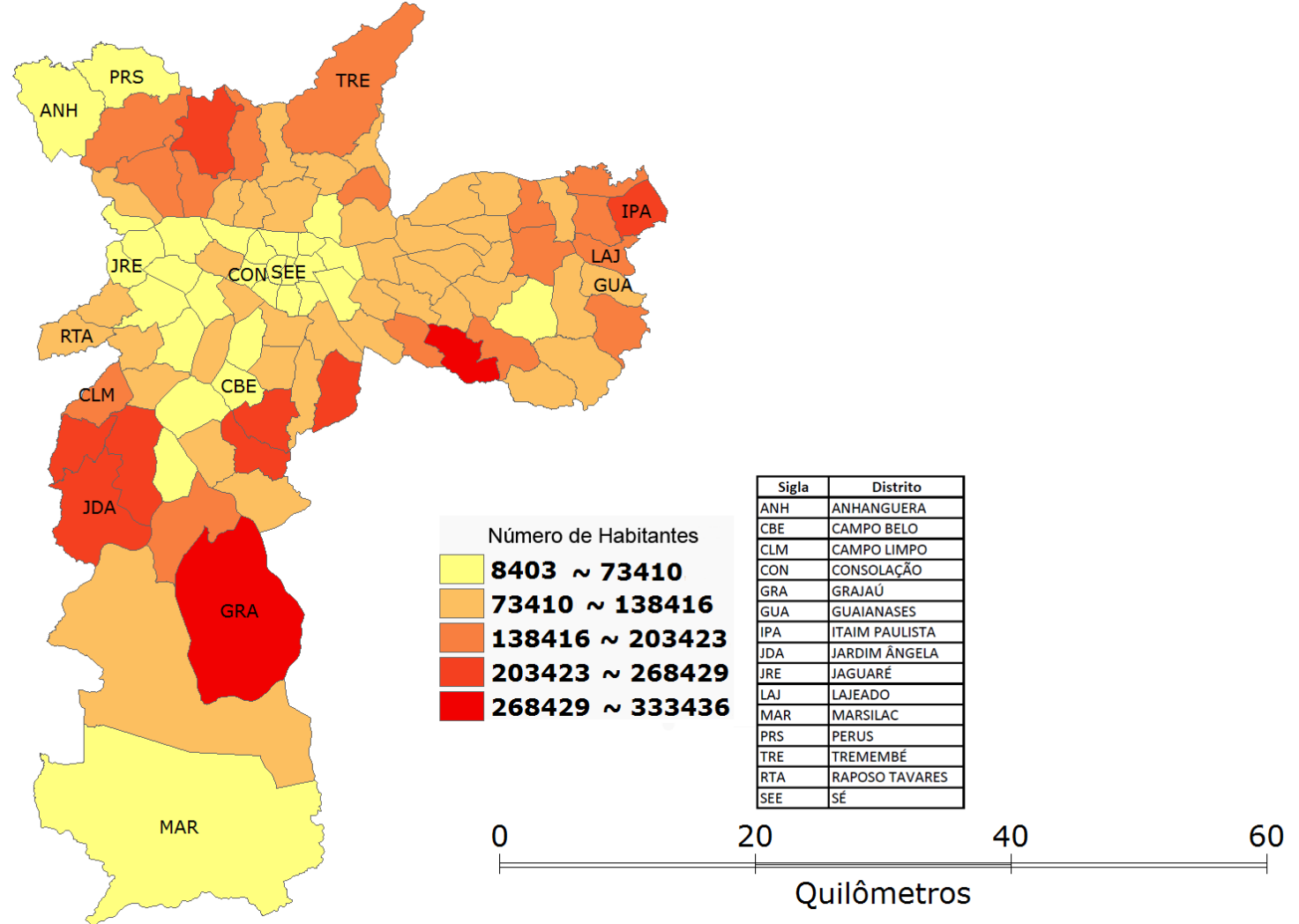

Fonte: Infocidade. Elaborado pelo autor. 
Mas tão interessante quanto perceber um enorme incremento populacional no distrito do Grajaú é compreender os fatores que conduziram a isso. Esses fatores vão desde os de ordem mais geral, que aconteceram de âmbito nacional e que rebatem nos lugares, causando graves consequências, como fatores específicos, de políticas locais para a cidade que acabam por aumentar a ocupação nessas áreas.

Como fatores de ordem mais geral podemos destacar a grave crise econômica vivida pelo país entre os anos 1980 e 1990, com altos índices de desemprego e perda de poder econômico, especialmente dos mais pobres, além da queda progressiva do poder geral de compra dos trabalhadores, em consequência da desvalorização real do salário mínimo.

Dados do Departamento Intersindical de Estatísticas e Estudos Socioeconômicos (Dieese) demonstram isso. Utilizando como base o ano de 2011 e o salário vigente na época, o Dieese fez um estudo mostrando os momentos de evolução e de retração do poder de compra com base nos valores relativos dos salários mínimos. O que se observa é que ele saiu de um patamar de $R \$ 1.202,29$, em 1940, quando da sua instituição, para atingir em 1959 o seu maior valor de R\$ $1.732,28$ e daí por diante uma queda progressiva até o ano 2000.

Entre as décadas de 60 e 80, o salário mínimo se manteve estável em patamares que variam entre $R \$ 600$ e $R \$ 700$, em valores corrigidos. Nos anos 80 e 90, o piso salarial apresentou uma expressiva desvalorização.

OLIVEIRA, Mariana. Disponível em: <http://g1.globo.com/economia/noticia/2011/02/veja-evolucao-do-salariominimo-desde-sua-criacao-ha-70-anos.html>. Acesso em: 14 ago. 2014.

Entre 1990-2000, a perca do valor real do salário mínimo foi bem maior do que $40 \%$, evidente que, num quadro de salários baixos e desemprego, as famílias pobres se viam cada vez mais obrigadas a cortar custos para sobreviver e um deles teve que ser o da habitação.

Paralelemente à grave crise econômica com o rebaixamento dos salários que se acentuaram durante os anos 1980-1990, houve também a mudança no padrão 
industrial, que havia se iniciado nos anos 1970, no mundo, mas que no Brasil ganha força definitivamente nos anos 1990.

A partir de então, as indústrias que haviam atraído trabalhadores desde a década de 1960 até meados dos anos 1980 passam a automatizar parte dos processos produtivos e a se deslocar espacialmente para a região que (Grosestein, Lencioni) denominam como Macrometrópole paulistana, um raio de $200 \mathrm{~km}$ da capital, fazendo com que muitos empregos fossem suprimidos, especialmente na Zona Sul no distrito industrial de Santo Amaro e Jurubatuba, que haviam sido um grande polo de atração de população para estsa área da cidade. Além dos processos de automação de muitas indústrias, ocorreu também "a aparente redução do emprego regular, em favor do crescente uso do trabalho em tempo parcial, temporário ou subcontratado". (HARVEY, 2010, p. 143).

O neoliberalismo na economia acabou por delapidar ainda mais a situação dos trabalhadores mais pobres das metrópoles dos países em desenvolvimento, através do corte de verbas em setores sociais essenciais como saúde, saneamento, habitação e educação.

O impacto dos ajustes de inspiração neoliberal em sociedades como as latino-americanas tem consequências bem mais dramáticas do que nos países centrais. Ele se dá sobre uma base estrutural e historicamente, desigual onde o Welfare state permitiu o acesso apenas restrito de direitos; onde o pleno emprego não passou de promessa; onde a previdência social alcançou apenas uma parte da sociedade, onde a cidadania se exerce, enfim, de forma restrita [...] Na década de 1980 e especialmente nos 1990, houve um recuo nos investimentos, em saneamento, quando o ciclo indispensável para universalizar o atendimento à população com água tratada não foi atingido e menos ainda o destino adequando do esgoto. (MARICATO, 2001, p. 30-39).

Contribuíram para piorar a questão da moradia a ausência de uma política habitacional do governo federal perante a demanda crescente de habitação por parte dos trabalhadores, extremante expropriados durante os anos 1990.

Cabe lembrar que, apesar das críticas e das consequências espaciais deixadas como legado para as grandes cidades brasileiras, o BNH efetuou uma grande produção habitacional durante os seus 22 anos de existência. 
Entre 1964-1986, o segmento da política brasileira para o setor da habitação contou com forte investimento do $\mathrm{BNH}$, fazendo com que o Brasil apresentasse maior êxito em programas de construção de habitações do que países como os Estados Unidos, Inglaterra e França. Durante o período em questão, foram construídas 4,5 milhões de unidades habitacionais, sendo que $33 \%$ deste universo destinado ao setor popular (de 1 a 3 salários mínimos). (SILVA, 2003, p. 15).

Após a sua extinção, a situação piorou e outras opções de habitação popular praticamente deixaram de existir, até recentemente ser criado o Minha Casa Minha Vida, no final dos anos 2000.

Desde o fechamento do Banco Nacional da Habitação (BNH), em 1986, o Brasil não apresentou um desenho consistente de política habitacional. A condição urbanística tem se deteriorado muito. (MARICATO, 2001, p. 65).

Do ponto de vista político, considerando-se no âmbito municipal, os anos 1990, que havia começado em São Paulo com a prefeita Luiza Erundina (19891992), que se demonstrava sensível às causas sociais, lutava para a urbanização de favelas e contra a remoção destas das áreas mais centrais, que tinha organizado toda a estrutura da Secretaria de Habitação (Sehab) para tal finalidade.

\footnotetext{
Mesmo considerando a incapacidade de conter a dinâmica de crescimento demográfico e urbano, pode-se afirmar que a forma de encarar o problema adotado pela equipe de habitação da gestão Luiza Erundina foi inovadora e formou um quadro de técnicos cujos objetivos foram qualificar o ambiente urbano, e que, por isso, mudaram a forma de gestão pública reconhecendo o direito à terra e moradia e fazendo projetos de intervenção quase cirúrgicos em áreas densamente ocupadas, respeitando sua forma de organização espacial e social, garantindo (mesmo que ainda não juridicamente) segurança de posse aos ocupantes. (WATHALY; FERRARA; SANTORO, 2009, p. 49). Mananciais: diagnóstico e políticas habitacionais. São Paulo. Instituto Sócio Ambiental.
}

Logo após as eleições municipais do ano de 1992, a cidade de São Paulo viu assumir como prefeito o Sr. Paulo Salim Maluf (1993-1996), que tinha orientações políticas e projetos completamente diferentes de sua antecessora, a prefeita Luiza Erundina. 
Tanto a administração Maluf (1993-1996), quanto a de seu sucessor e apadrinhado político, o senhor Celso Pitta (1997-2000), foram marcadas por medidas específicas que refletiram tanto para a cidade como um todo como para a área de proteção de mananciais mais especificamente.

$\mathrm{Na}$ administração de Paulo Maluf ocorreram dois movimentos aparentemente desassociados, mas que mostraram seu caráter complementar, ou seja, duas faces de uma mesma moeda, que foram uma série de obras, especialmente no setor sudoeste da cidade, com a expulsão de diversas famílias que moravam em favelas nessa área extremante valorizada de São Paulo e a anistia para moradias irregulares, além do aceno para anistia dessas moradias em áreas de proteção aos mananciais.

Sobre sua política urbana, podemos afirmar que, primeiramente, Maluf cria expectativa de regularização fundiária em área de mananciais, a partir da lei de anistia aos imóveis irregulares proposta ao final de 1993. Por um tempo, a proposta de anistia parecia que seria aplicada inclusive em mananciais, o que gerou controvérsias jurídicas e estimulou um forte adensamento da região já ocupada e novas ocupações [...] A política de anistia vem acompanhada de uma política de expulsão da população favelada de áreas valorizadas da cidade, com produção de poucas novas habitações, com graves reflexos na região de mananciais. (WHATELY; FERRARA; SANTORO; 2008, p. 50).

Um exemplo disso que se tornou clássico foi o estudo que Mariana Fix fez, sobre a Operação Urbana Faria Lima e a Operação Urbana Água Espraiada que resultou na expulsão, milhares de pessoas das favelas que residiam em áreas centrais mais valorizadas e que foram parar nas áreas de proteção de mananciais.

Das favelas de Água Espraiada, mais de 50 mil moradores foram expulsos - muitos deles morando em casas de alvenaria construídas havia mais de 10 ou 20 anos - e tiveram poucas alternativas além de ir para outras favelas, em bairros distantes, como Jardim Ângela, Jardim São Luís, Cocaia ou Grajaú. Grande parte foi parar nas margens das represas Billings e Guarapiranga, região que apesar das fortes restrições determinadas pela Lei Estadual de Proteção dos Mananciais, desde 1979, 
tem sido intensamente ocupada por aqueles que, como os moradores de Espraiada, não têm alternativa. (FIX, 2001, p. 134).

Ainda segundo Whitaker, ao se referir a esse processo estudado por Mariana Fix, coloca que:

Esses casos levantados por Fix aconteceram realmente a partir da gestão Maluf, entre 1995 e 1996. Para dar maior precisão, em relação à Favela Jardim Edith, o início da remoção deu-se em novembro de 1995, e algumas famílias foram parar na Favela São Domingos na Billings, após receberem uma verba de auxílio. (WHATELY; FERRARA; SANTORO; 2008, p. 51).

Paralelamente a esse processo de exclusão da população mais pobre de favelas nas áreas mais valorizadas pelo mercado e anistia a ocupações irregulares, ainda essas duas administrações Maluf-Pitta concentraram o maior volume de investimentos em áreas mais centrais. Um caso emblemático disso aconteceu na gestão Maluf e é narrado por Maricato ao se referir a gastos públicos em áreas centrais da cidade, nesse caso sobre as obras da Operação Urbana Águas Espraiadas, justamente a área onde a população favelada estava sendo removida naquele período:

Em São Paulo, o caso é bem mais radical, a prefeitura investiu em apenas três túneis a quantia de US $\$ 1,2$ bilhões de dólares que é equivalente a 4 anos do orçamento total de um município como o de Belém, por exemplo. (MARICATO, 2002, p. 166).

Isso não significa que não estivesse havendo algum investimento nas áreas periféricas, em especial nas áreas de proteção aos mananciais, mas se compararmos esse setor da cidade com os investimentos em áreas mais abastadas, eles se mostravam muito inferiores e muito aquém das necessidades das áreas periféricas.

Marques e Bichir, em seu estudo que reconstrói os investimentos públicos e a sua distribuição espacial, analisando o período que percorre de 1978-1998, conclui sobre as administrações Maluf e Pitta: 
Os maiores investimentos relativos em espaços de ricos encontram-se na administração Maluf, com $24,9 \%$ de seus recursos destinados aos espaços da classe média e $24,7 \%$ aplicados nas áreas de classe alta. Em outro patamar, destacam-se seus investimentos nas áreas de pobres consolidados $(22 \%)$ e nas áreas de classe média baixa e de pobres recentes (13,9 e 10,5\% respectivamente) as administrações Maluf e Pitta se destacam pela maior proporção de investimentos destinados às áreas das classes altas, que receberam, aproximadamente, $50 \%$ dos recursos destas administrações. A administração Jânio Quadros, embora com menor destaque, também tem um saldo socialmente regressivo. Dentre as demais administrações, Setúbal e Reynaldo apresentam um saldo levemente redistributivo, mas as diferenças entre as proporções dos dois espaços são muito pequenas. Já as administrações Covas, Curiati e Erundina apresentam perfis altamente distributivos, com as proporções dos investimentos destinados a áreas classificadas como das classes baixas superando muito as destinadas para áreas de classe altas. (MARQUES E BICHIR, 2001, p. 19-20).

Gráfico 3. Perfil de investimentos de prefeitos de São Paulo

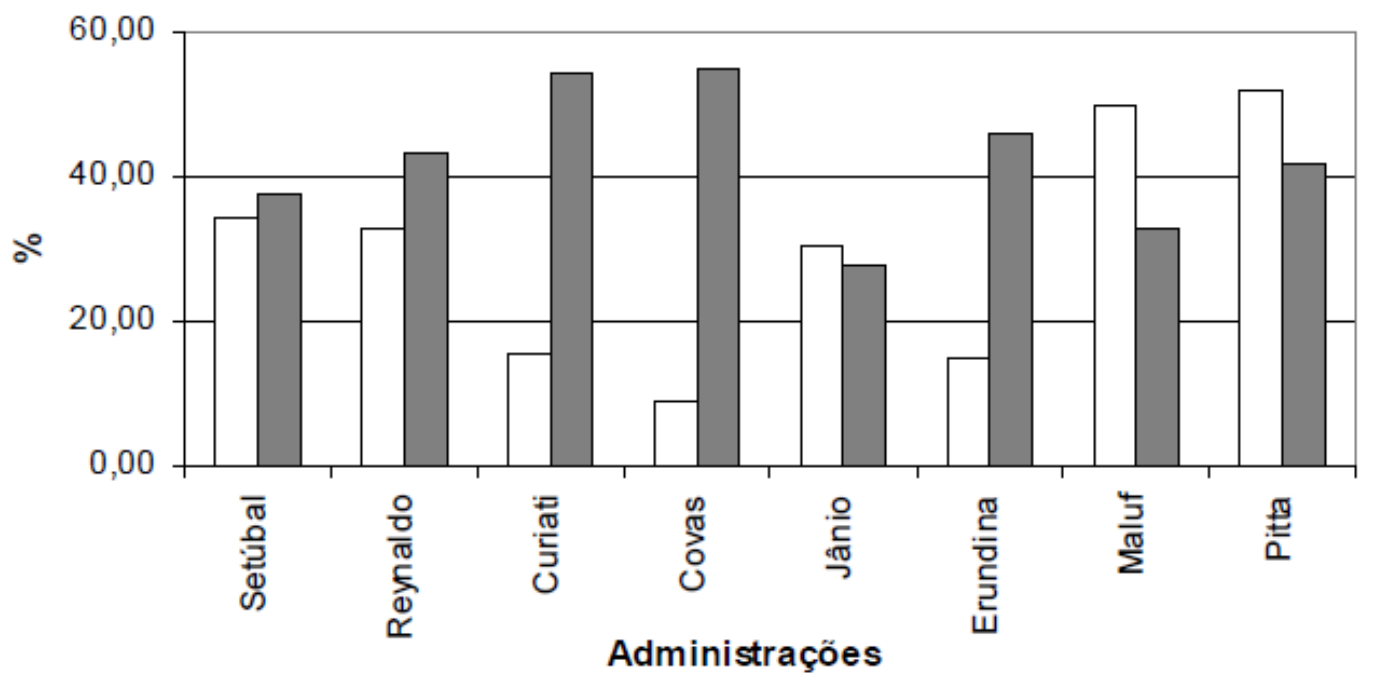

$\square$ classes altas (\%)

$\square$ classes baixas (\%)

Fonte: Marques e Bichir, p. 20. 
Cabe lembrar que Marques e Bichir, aprofundando suas análises sobre a distribuição dos investimentos neste intervalo de vinte anos entre 1978-1998, concluem que:

\begin{abstract}
Se realizarmos esse exercício apenas para os distritos dos espaços das classes baixas (pobres recentes e consolidados) e cruzarmos esta informação com os investimentos por distrito em cada governo, descobriremos que, para as administrações Reynaldo e Setúbal (e apenas para elas), os investimentos nos espaços das classes baixas estão estatisticamente correlacionados com a presença de áreas de alto padrão nos distritos. Isto é, se essas administrações investiram uma parcela significativa dos seus recursos em áreas periféricas, como vimos antes, o fizeram quase sempre nos distritos periféricos com maior presença de áreas de alto padrão. $O$ único governo de direita que subsiste como redistributivo, portanto, é a administração Curiati. (MARQUES e BICHIR, 2001, p. 21-22).
\end{abstract}

O que significa que Reynaldo de Barros e Olavo Setúbal investiram na periferia apenas em áreas consolidadas, enquanto que nas áreas mais carentes seus investimentos foram pífios. Podemos concluir que entre 1978-1998 - em poucos períodos com exceção dos rápidos períodos Curiati, 1982-1983, Covas. 1983-1985, e Erundina, 1989-1992 - ocorreram poucos investimentos na periferia da cidade de São Paulo, o que só fez agravar a situação, especialmente durante grande parte dos anos 1980 e na maior parte dos anos 1990, mais especificamente entre 1993-2001. Com o aumento de ocupações em áreas de proteção de mananciais, houve também uma precarização ainda maior da vida dos mais pobres que foram morar nesses locais, que apresentavam um grande aumento da violência, sem falar do desemprego nesse período. 


\section{Capítulo 3: Equipamentos urbanos e condições de vida na Península do Ribeirão Cocaia}

\subsection{Crescimento populacional recente}

A Península do Ribeirão Cocaia, ao contrário do que grande parte da literatura coloca, como a periferia sendo uma área de pobreza homogênea, não se enquadra totalmente nesses parâmetros, uma vez que há um mosaico de usos do solo e diferentes tipos de ocupação, o que torna a sua análise, por vezes, muito complexa e que as teorias sobre o urbano tradicionais não dão conta de explicar. Temos desde usos do solo que se desenvolveram graças ao incentivo estatal, como é o caso da Cohab Faria Lima, como ocupações recentes, no caso da Ocupação Anchieta, que aconteceu a partir 2013, outras ocupações merecem um estudo bem mais aprofundado, como ocupações antigas, caso da favela Sucupira, em que pouco se viu mudar as condições de vida dos trabalhadores que lá residem, ou áreas em que ocorreu o clássico modelo de ocupação periférica, com o tripé autoconstrução/casa própria/loteamento clandestino, como é o caso do Parque Residencial Cocaia, e que, hoje, grande parte da área do bairro já está regularizada na prefeitura, e também com ocupações sem regularização jurídica no Cantinho do Céu, e alguns poucos remanescentes de antigas chácaras neste mesmo bairro.

Assim como temos diversos tipos de ocupação do solo, tivemos vários tipos de intervenções estatais ao longo dos anos, como processos de regularização/expulsão, urbanização/desfazimentos; entretanto, o que se tem demonstrado é que a solução ainda parece algo distante tanto do ponto de vista ambiental quanto do ponto de vista social.

Em relação ao crescimento recente, parece ter havido de 2000 para cá um certo processo de arrefecimento em relação a esse crescimento. De fato, ele não parou de ocorrer, mas as taxas diminuíram consideravelmente se comparado ao período de maior incremento demográfico do distrito, que aconteceu entre 1991 2000, no qual, como citado anteriormente, embora as taxas não tenham sido as mais altas da história, eram bem mais altas que as da metrópole: $6,22 \%$ ao ano para o distrito do Grajaú, enquanto para São Paulo era $0,88 \%$ ao ano; entretanto, o incremento populacional em números absolutos foi o maior registrado do distrito. 
O período 2000-2010 serve para consolidar a liderança do distrito do Grajaú como o mais populoso da cidade de São Paulo. Nesses dez anos, ele apresenta taxas de crescimento um pouco superiores às da metrópole paulista, 0,79\% para o distrito do Grajaú e 0,76\% para o município de São Paulo.

A população passou no ano de 2000 de 333.436 para 360.787 habitantes, com um incremento em termos de população absoluta entre 2000-2010 de 27.351 pessoas. Isso não seria tão relevante se o distrito não estivesse inserido grande parte dele em áreas de proteção aos mananciais e com restrições à ocupação e já não estivesse extremamente povoado. E, ainda, temos de lembrar que houve remoções de população nesse período para a construção do parque linear que a Prefeitura chama de Cantinho do Céu, e os moradores chamam de Lago Azul, e operações de desfazimento durante a administração Kassab (2006-2008), quando assumiu a prefeitura substituindo José Serra (2009-2012), que removeu pessoas das áreas de mananciais sem proporcionar uma solução clara para o problema da habitação, como descreve Silva (2011), em sua tese na qual analisa como as remoções ocorreram na Vila Madeirite. A solução era:

\footnotetext{
"O encaminhamento de 'indesejáveis' para sua 'terra natal' ou a busca de retirada do lugar onde se tornaram um problema [...] No Jardim Gaivotas não deixa de ser interessante o fato de que, a despeito dos moradores removidos serem excluídos de todos os direitos sociais, como o encaminhamento habitacional e o auxílio financeiro, lhes é oferecido o auxílio financeiro para deixar a cidade, numa espécie de gestão da população que os coloca ao mesmo tempo dentro e fora das relações com o Estado, ao excluí-las das responsabilidades públicas ao mesmo tempo que o Estado atuando sobre elas, pela tentativa de retirá-las definitivamente da cidade. A ironia maior é que tal mecanismo é apresentado como um 'direito', ao menos uma concessão feita pelo Estado, que encontra seu paradoxo na resposta dada por uma moradora à assistente social que vem Ihe oferecer o 'benefício': 'eu nasci em Santo Amaro'. Se o único "direito" que esta moradora tinha era o de voltar para a sua terra natal, que dizer quando sua terra natal é a própria cidade da qual ela é chamada a se retirar? (Silva, 2011, p. 97-98).
} 
Há uma dúvida quanto aos problemas dessa área de mananciais: ou não foram resolvidos, ou alguma coisa está acontecendo em relação às soluções propostas, pois mostram que elas não vêm sendo muito eficientes. $E$ com base nos trabalhos realizados em campo e nos últimos dados coletados para esta pesquisa, é possível também afirmar que, apesar de todo esse aparato repressivo, mesmo assim as ocupações não foram controladas e estão voltando e até aumentando.

O último dado sobre a população de 2014 e o mapa de população absoluta, elaborado a partir dos dados mais recentes da Fundação Seade, mostram que a população estava neste ano em 372.467 habitantes, ou seja houve, um incremento populacional de 11.980 pessoas em um intervalo de apenas quatro anos, o que dá uma taxa de crescimento próxima de $0,81 \%$ ao ano, e que sugere um leve aumento novamente na taxa de crescimento do distrito, o que tende a agravar ainda mais a situação de espoliação urbano-ambiental em certas áreas dentro do distrito como pode ser observado em campo.

Um dos lugares que está crescendo novamente é uma área diante do parque linear, onde já havia sido removida a população, dentro da borda da represa, com habitações recém-construídas, que apresentam um alto grau de precariedade, com a falta de água encanada, de esgoto, e até de fossa asséptica. Segundo a líder comunitária do Cantinho do Céu, Josiane:

A pobreza ainda é muita, tanto que as pessoas levam até o material que era encostado para construção do parque linear, e teve muita invasão, invasão em cima de invasão, tanto que está até fugindo ao controle social. 
Figura 24. População absoluta dos distritos de São Paulo — 2014

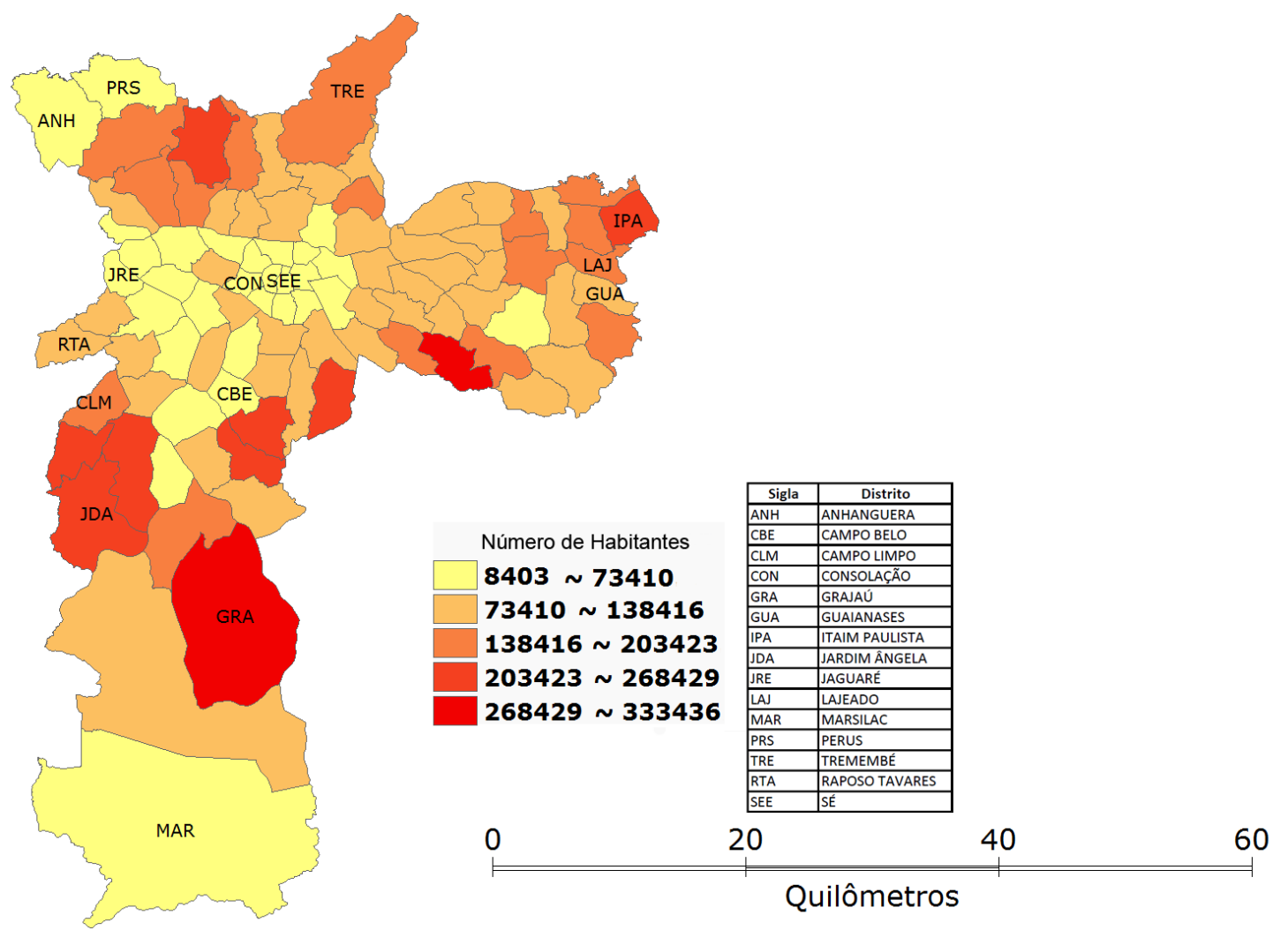

Fonte: Infocidade. Elaborado pelo autor.

Figura 25. Cantinho do Céu

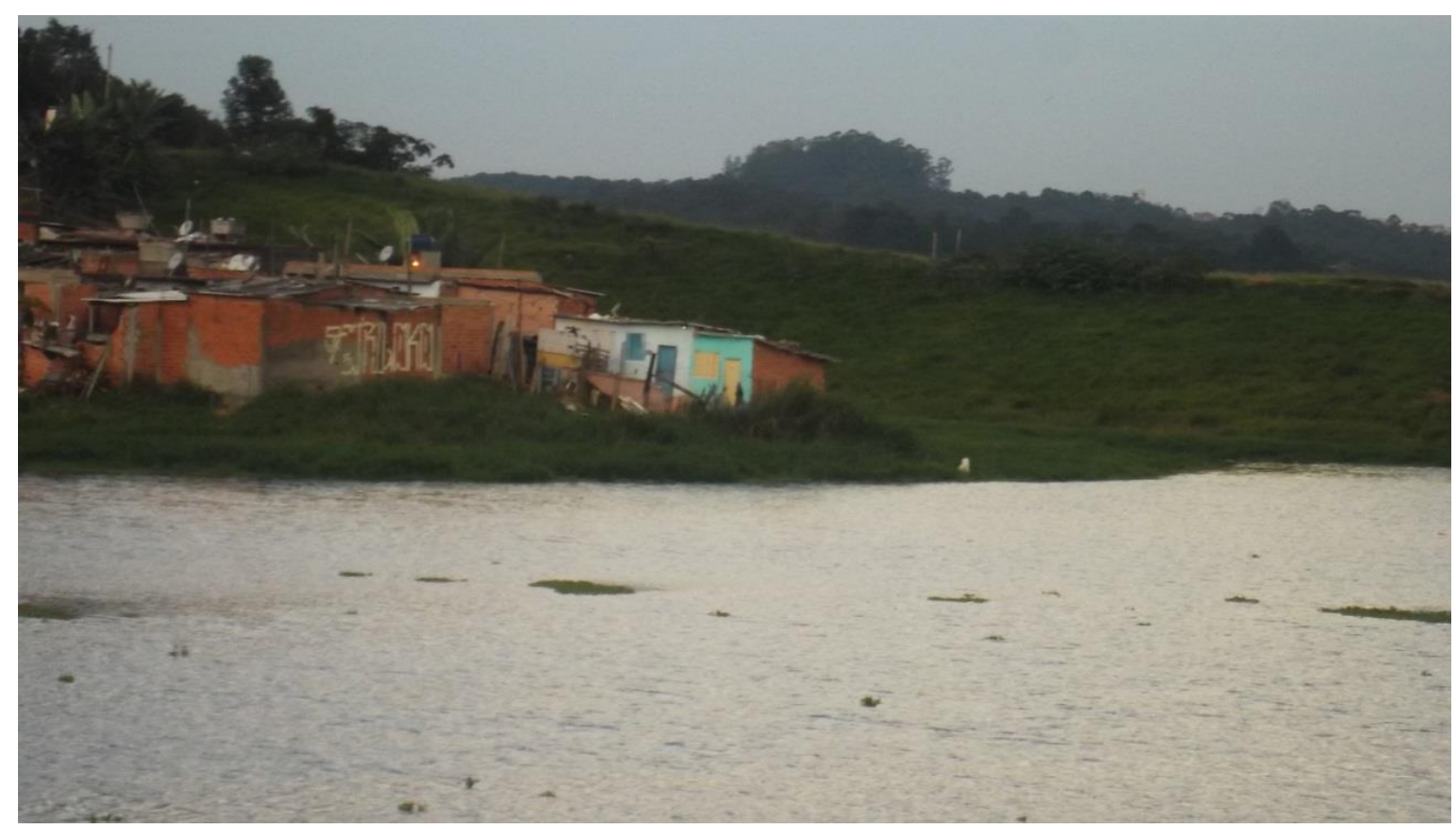

Habitações precárias construídas no Cantinho do Céu, vistas do parque linear, 30 de maio de 2015. Fonte: Foto do autor. 
Figura 26. Cantinho do Céu

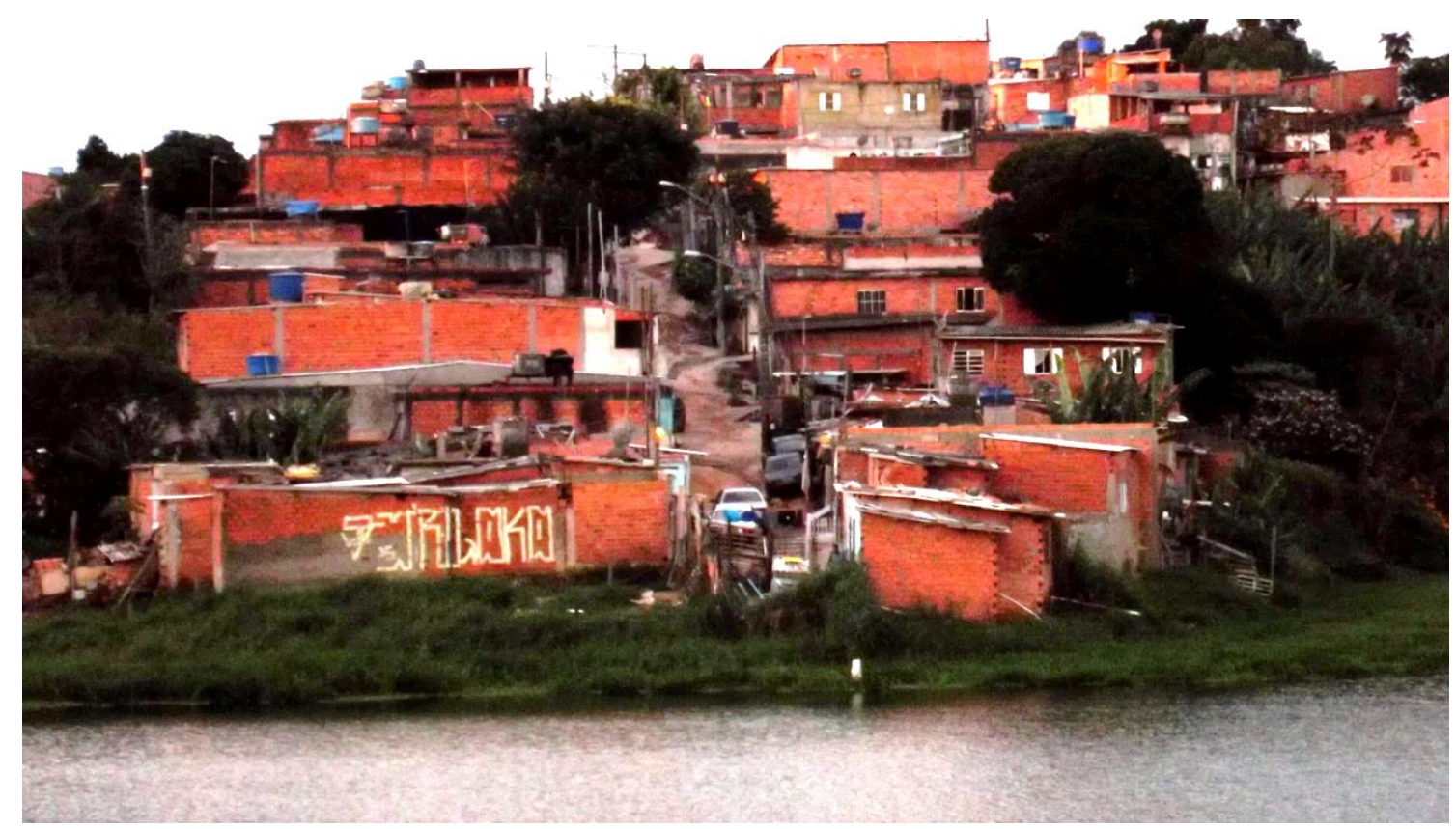

Vista de habitações construídas no parque linear conhecido como Cantinho do Céu, 30 de maio de 2015. Fonte: Foto do autor.

Dessa maneira, apesar de um certo arrefecimento nas taxas de crescimento do distrito do Grajaú, não significa que ele parou de crescer, e a questão mais séria é que ele volta a crescer nos pontos do distrito que apresentam maiores espoliações socioambientais: nas margens da represa, ao lado do parque linear no Cantinho do Céu e nas bordas da represa na favela Sucupira no Grajaú, onde a ocupação está abaixo da cota máxima de inundação do reservatório. Essa ocupação está tomando características de perenidade com formação de casas de alvenaria. Nos últimos meses, há ocupações em cotas ainda mais abaixo. Segundo Cleide, presidente da Associação Amigos de Bairro do Grajaú, e Joana, líder comunitária da favela Sucupira:

Essa ocupação [sic] são de pessoas trazidas para um albergue construído recentemente pela prefeitura, e essas pessoas são da Cracolândia, eles trazem essas pessoas de perua para o albergue, eles chegam aqui não querem ficar no albergue, fogem e ficam nas ruas, e estão montando essa comunidade aqui em baixo. 
A comunidade nova que está se formando tem as características clássicas das favelas das grandes cidades brasileira surgidas nos anos 1970: são de madeira em áreas que apresentam alto risco ambiental, de inundações, de contaminação por esgoto e sem saneamento básico.

Além disso, os moradores do bairro estão entrando em conflitos com estes novos moradores que estão se instalando no bairro. Segundo Cleide:

Nós não temos nada contra essas pessoas, mas como a Prefeitura instala um albergue entre três escolas, onde estudam centenas de crianças? E mais: estão aumentando os casos de assalto no bairro, e são essas pessoas, não tínhamos ultimamente assaltos no bairro como estão acontecendo agora depois da instalação deste albergue.

Durante a visita a campo, foi observado o caráter de precariedade das novas habitações, que estão se instalando abaixo da favela Sucupira, e um fato que não é comum na periferia: um grande número de pessoas dormindo nas ruas. $\mathrm{A}$ presença de moradores de rua em espaços periféricos é algo relativamente novo e que já está gerando um grande conflito social, que, se não forem tomadas atitudes por parte do poder público, logo causará grandes problemas.

Figura 27. Morador de rua dormindo em praça do Grajaú

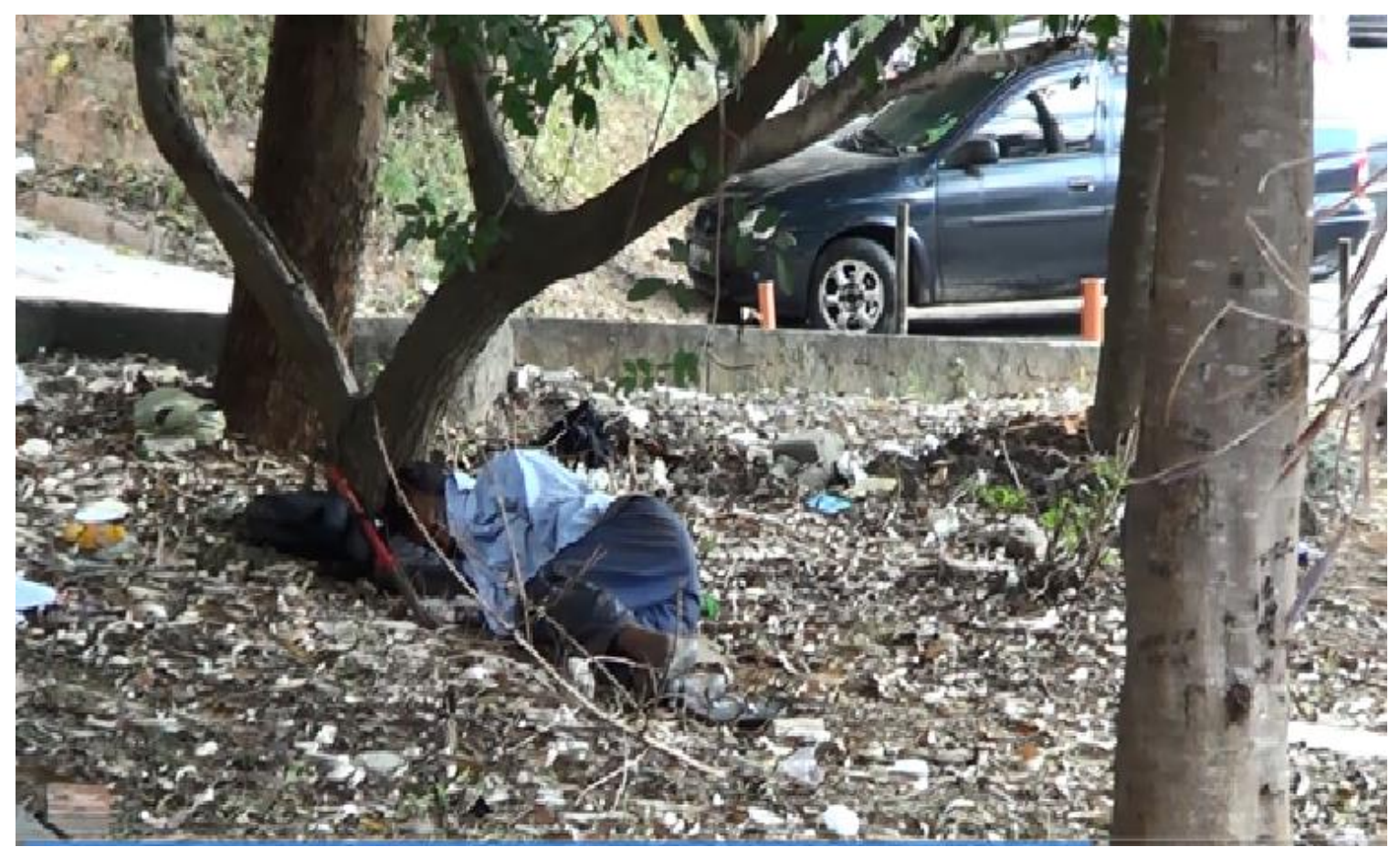

Novo fenômeno urbano no Grajaú: morador de rua, 30 de abril de 2016. Foto do autor. 
Isso mostra novamente que não há homogeneidade na periferia, nem em um mesmo distrito. Muito embora o distrito do Grajaú tenha se desenvolvido muito em algumas de suas regiões, como, por exemplo, nas áreas próximas da linha férrea Estação Grajaú da Companhia Paulista de Transportes Metropolitanos (CPTM), nos bairros Jardim São Paulo, Parque América, ainda existem lugares de grande precariedade e de espoliação urbano-ambiental, como é o caso de quase todo o bairro Cantinho do Céu e partes do próprio Grajaú, como caso da favela Sucupira, da Ocupação Anchieta e da nova ocupação, que ainda não tem nome, que se localiza abaixo da Sucupira, e em uma cota bem abaixo do nível máximo de inundação do reservatório, mas que mostra um fenômeno totalmente novo acontecendo nesta área periférica: pessoas sendo transferidas pela prefeitura para albergue situado perto da Cohab Faria Lima e construindo seus barracos., Não é mais apenas a pobreza que transforma trabalhadores em seres indesejáveis para parte da população e das elites nos centros da cidade, mas. agora, também os que têm problemas com substâncias ilícitas são obrigados a residir nas periferias mais distantes para não causarem transtornos em locais de grande visibilidade da cidade.

\subsection{Condições de saúde, habitação e saneamento urbano}

\subsubsection{Saúde}

As condições de saúde não são as melhores no distrito do Grajaú, e piores ainda em uma parte significativa do distrito de Península do Ribeirão Cocaia.

O número de leitos do Sistema Único de Saúde (SUS) é de 240 para uma população de 372.467 habitantes, segundo dados de 2014 da Fundação Seade. Cabe lembrar que não existe nenhum hospital particular com leitos disponíveis no subdistrito do Grajaú.

Segundo a Organização Mundial da Saúde (OMS), o número de leitos deve ser entre 3-5 por cada mil habitantes. Para atingirmos a proporção mínima de 3 leitos por mil habitantes para a população residente no distrito do Grajaú, seria necessário aumentar para mais de 4,5 o número de leitos, o que significaria ter que construir, pelo menos, mais de 15 hospitais na região, investimento que não vem sendo feito, nem parece estar nos planos imediatos tanto do governo do Estado de 
São Paulo quanto da prefeitura do município. Em outros países, a proporção de leitos é bem maior. Segundo a Associação de Hospitais e Serviços de Saúde do Estado da Bahia, “Japão e Alemanha, por exemplo, têm média de 13,7 e 8,2 leitos para mil habitantes, respectivamente. Nos Estados Unidos a média é de 3 leitos para mil habitantes".

No munícipio como um todo, considerando tanto os hospitais estatuais quanto os municipais, o número de leitos da rede SUS é de 17.761 leitos, o que para os padrões mínimos da OMS seria suficiente para atender uma população de 5.920.333 habitantes, levando-se em conta que a população da cidade de São Paulo, corresponderia a 11.967.825 habitantes, segundo estimativas do IBGE, ou seja, ainda que dobrássemos o número de hospitais, teríamos número mínimo de leitos de 3 por habitantes um pouco abaixo do ideal. Todavia, observando o número de leitos do SUS para a população do Grajaú, ele é muito pior do que a média da cidade. Na média, a cidade possui 1 leito SUS para pouco mais de 2 mil habitantes, enquanto que o distrito do Grajaú possui 1 leito para mais de 7 mil habitantes, o que mostra as condições de saúde muito graves na área de estudo. ${ }^{1}$

Comparando com outros distritos da cidade, como o Jardim Paulista, que, segundo Seade (2014, p.12), possui apenas um total de 2.923 leitos SUS para uma população de 89.722 habitantes o que proporcionalmente atinge a média da Organização Mundial da Saúde (OMS), até ultrapassando-a, ficando em 3,6 leitos por mil habitantes, o que demonstra além da carência de serviços públicos de saúde a sua má distribuição no espaço da cidade. O distrito que possui mais habitantes oferece um dos piores serviços de saúde do munícipio. Para Josiane,

A minha luta é contínua, assim como a de outros líderes, por mais creches, mais escolas, porque o CEU que tem aqui não comporta a quantidade de

${ }^{1}$ Para esse estudo, estamos considerando o número de leitos apenas do Sistema Único de Saúde (SUS) disponível para a população do subdistrito do Grajaú. Evidentemente que uma parte da população do município de São Paulo possui plano de saúde e convênio médico e é atendida pela rede de saúde privada; entretanto, boa parte da população do subdistrito do Grajaú não, pois a renda per capta do distrito é baixa e uma parte considerável dessa população não participa do mercado formal de trabalho, ficando mais difícil ter acesso a esse serviço na rede particular de saúde. 
crianças, e principalmente a luta hoje é por um posto de saúde, porque não temos aqui, o que usamos é o posto de saúde lá do Cocaia.

\subsubsection{A situação de habitação}

A situação de habitação no distrito do Grajaú é bastante complexa, uma vez que temos desde áreas que hoje já são muito valorizadas e que possuem uma infraestrutura boa, a áreas de grande precariedade, tanto no distrito, que apresenta uma área total de $92 \mathrm{~km}^{2}$ no total, como na Península do Ribeirão Cocaia, que apresenta uma área de $19,8 \mathrm{~km}^{2}$, cerca de $21 \%$ da área total do distrito.

Nota-se uma grande valorização dos imóveis nas áreas que são mais consolidadas a ocupação dos bairros, especialmente ao longo da via férrea, mais exatamente onde se inicia a principal porta de entrada para o Grajaú: a avenida Belmira Marin, antiga Estrada do Bororé. As casas nesse local chegam a alcançar valores altos, entre $R \$ 400$ mil a $R \$ 800$ mil reais.

Figura 28. Construções próximas da estação de trem da CPTM do Grajaú

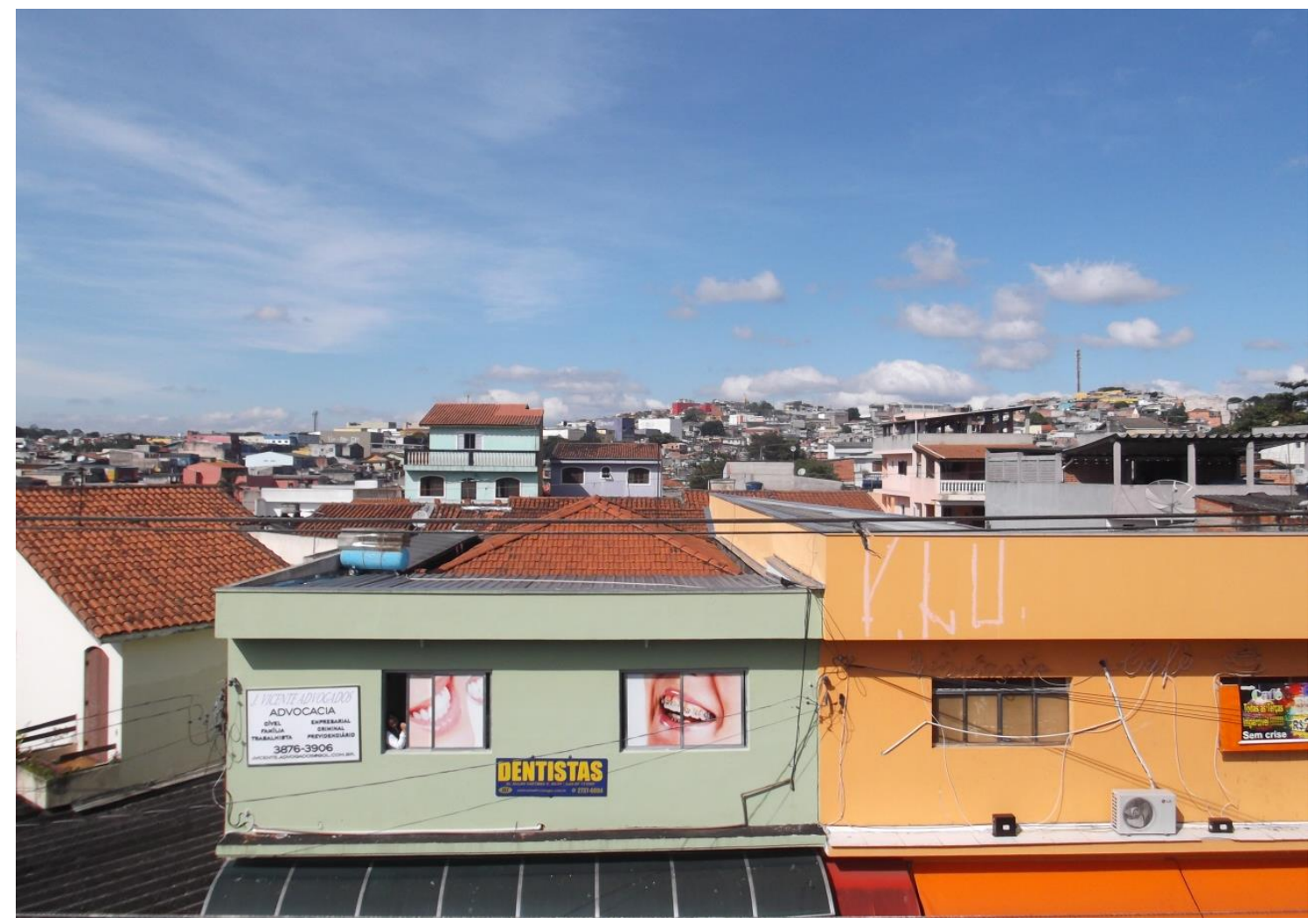

Imóveis nas proximidades da Estação de trem da CPTM do Grajaú, 28 de abril de 2016. Note-se o bom padrão de construção das casas. Foto do autor. 
Nessa avenida, nos seus primeiros 1,5 km, destacam-se diversas lojas de redes populares e, mais recentemente, serviços mais especializados, como uma clínica do laboratório Lavoisier, que até bem recentemente se concentrava em bairros mais nobres e áreas mais elegantes da cidade, o que mostra, mesmo que indiretamente, certa melhoria na renda da população do bairro.

Além da presença desse laboratório, outras redes de lojas populares estão na região, o que comprova que há uma demanda solvente para o tipo de produtos e de serviços oferecidos. Estão no bairro lojas populares como Casas Bahia, Lojas Marabrás, e vários bancos como: Banco do Brasil, Bradesco e Caixa Econômica Federal. Entretanto, a partir do número 1500 dessa avenida, a paisagem começa a mudar, apresentado uma variedade de usos do solo muito maior, com grande quantidade de habitações que apresentam alto grau de precariedade.

Além desse primeiro ponto de comércio, existem outros dois de destaque: um outro polo local que é no centro do Grajaú, praticamente ao lado da CohabGrajaú, na altura do número 2500 da avenida Belmira Marin, que se instalou durante a década de 1990; e outro mais recente na rua Pedro Escobar, que corre praticamente como divisor de águas, separando os bairros Parque Residencial Cocaia e Cantinho do Céu.

Tanto no Grajaú próximo à Cohab, quanto no bairro Cantinho do Céu, nota-se uma grande discrepância nessas habitações. No bairro Grajaú, temos instalada a Cohab Brigadeiro Faria Lima, que, segundo Cleide, presidente da Associação de Moradores do Grajaú, é considerada uma área mais nobre do bairro, onde morariam os "ricos".

Praticamente ao lado da Cohab, a comunidade Sucupira, que apresenta toda ordem de problemas e ausência de infraestrutura urbana como ausência de saneamento básico. Essa região recebe toda a carga de esgoto não tratada que vem da Cohab, passando na porta da casa das pessoas, e desaguando diretamente na Billings, uma vez que essa comunidade está instalada dentro da borda da represa. 
Figura 29. Comunidade Sucupira

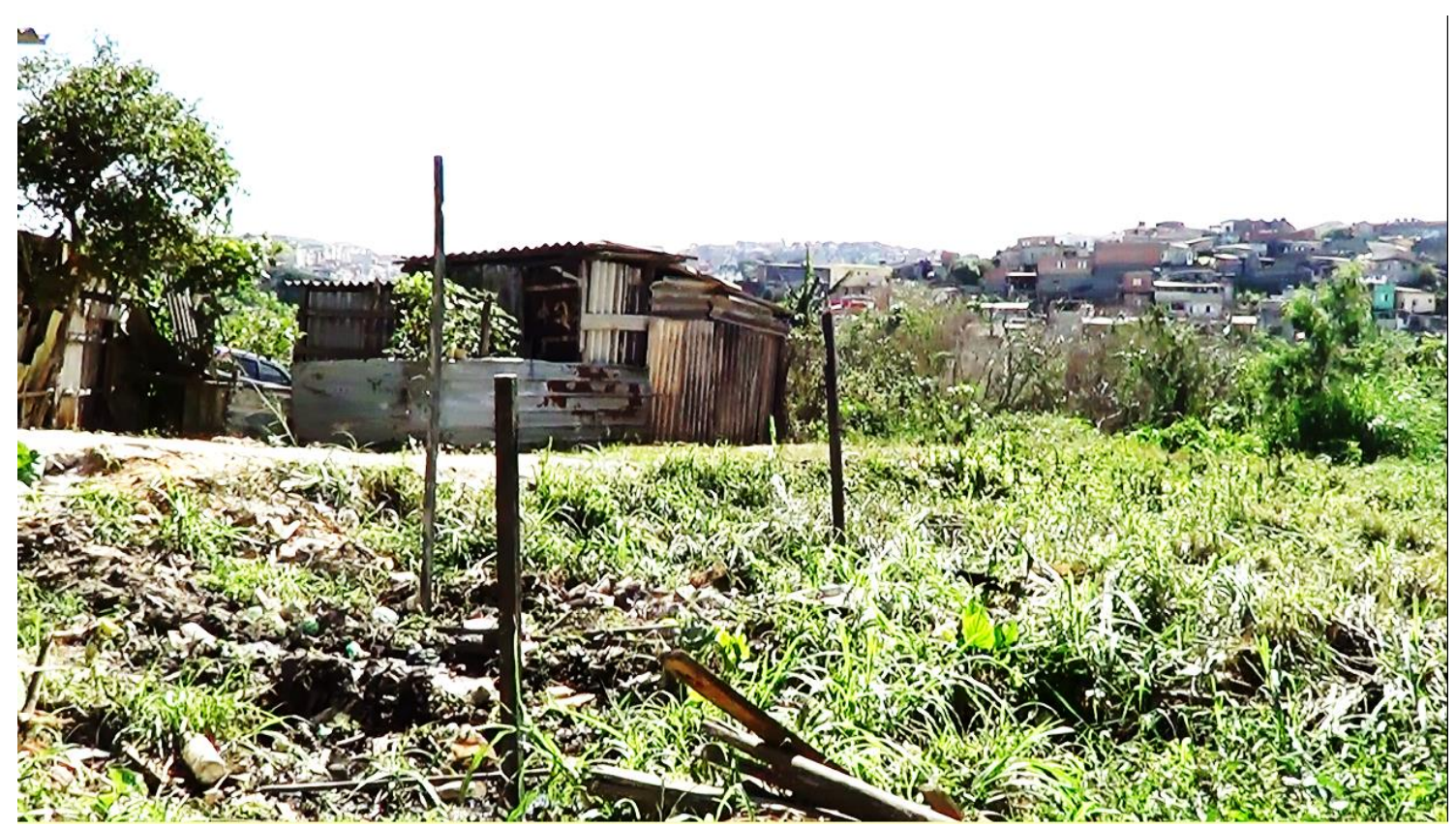

Habitações precárias na Comunidade Sucupira, 30 de abril de 2016. Foto do autor.

Já no Cantinho do Céu, o bairro se divide nitidamente na metade da rua Francisco Lopes Solano, onde foram feitas obras de infraestrutura para receber o parque linear que chegaria ao Cantinho do Céu, mas que, segundo seus moradores, foi feito no Lago Azul, não tendo chegado na área onde realmente está localizado o Cantinho do Céu. Na área urbanizada, as casas se valorizaram muito, porém, em visita de campo, a líder comunitária Josiane fez uma advertência:

Vocês acham que esse aqui é o Cantinho do Céu, mas esse aqui não é o Cantinho do Céu, se vocês quiserem realmente conhecer o verdadeiro Cantinho do Céu e suas precariedades e carências, venham outro dia que nós vamos lá.

Ela dissera isso querendo se referir à grande precariedade que existe ainda na maior parte do bairro, que não foi contemplada com as obras de infraestrutura realizadas, até a parte onde começou o parque linear. 
Com relação à questão da habitação, um fato chamou muito a atenção: a ocupação recente, chamada de Ocupação Anchieta. Esse ato se deu mesmo após a prefeitura de São Paulo, na gestão de Gilberto Kassab (2006-2012), ter apostado na política de desfazimento, ou seja, de remoções forçadas, pagando alguma indenização às pessoas, e posteriormente realizando algumas obras. A ideia de congelamento significa paralisar totalmente a ocupação da área de mananciais, conforme consta da política da administração Kassab e da própria lei especifica da Billings № 13.579/09, que fala sobre áreas, de congelamento das ocupações, além de áreas de recuperação ambiental, ocupação dirigida e das áreas de preservação.

No seu capítulo XI sobre licenciamento, regularização, compensação, fiscalização de atividades Seção III, da regularização de Assentamentos Habitacionais de Interesse Social — ARA 1, no seu Art. 77 versa:

\footnotetext{
São passíveis de regularização os assentamentos habitacionais de interesse social enquadrados como Área de Recuperação Ambiental (ARA 1) e implantados até 2006, conforme verificação na última imagem de satélite de alta resolução do referido ano.
}

Isso significa que apenas os assentamentos implantados até 2006 poderiam ser regularizados. Se observarmos a Ocupação Anchieta percebemos novamente que, devido à falta de alternativas habitacionais para a população, os loteamentos e as ocupações continuam acontecendo e persistirão à revelia da lei.

\subsubsection{Saneamento urbano}

A cidade de São Paulo de maneira geral apresentou uma certa melhora nos índices gerais de saneamento urbano entre o período de 2000-2015.

Se analisarmos os dados sobre coleta de esgotos no ano 2000, havia um total de domicílios de 2.985.997, sendo que 2.604.791 eram ligados à rede de esgotos e 381.198 não haviam ligação, proporcionalmente o que corresponderia a $87,2 \%$ ligados à rede, e 12,8\% sem a coleta de esgoto. É importante lembrar aqui que nem todo esgoto coletado é tratado ainda hoje. 
Os números do distrito do Grajaú para o ano de 2000 eram bem piores se comparados à média do município. De um total de 86.223 , apenas 33.628 estavam ligados à rede, ou seja, 52.595, que corresponde à maioria dos domicílios, não se encontravam conectados à rede geral de coleta. Em termos percentuais, $39 \%$ do esgoto é coletado e $61 \%$ não.

Já no ano de 2010, o munícipio de São Paulo apresenta um total de 3.570.406 residências, a coleta esgoto é realizada em 3.285.168 domicílios e permanecem sem coleta 285.238. Esse número de coleta representa $92 \%$ de esgoto coletado e apenas $8 \%$ de esgoto não coletado para o município.

No distrito do Grajaú em 2010, esses números com relação à coleta de esgotos tiveram uma melhora em comparação ao ano de 2000. Um total de 102.976 domicílios nesse ano; o número de domicílios com coleta de esgoto passou para 74.638 e não coletado 28.308 domicílios. Isso significa um grande avanço, pois atualmente $72,5 \%$ das residências estão atendidas com coleta de esgoto, faltando $27,5 \%$, que ainda não são.

Houve um salto em termos de porcentagem em dez anos de $33,5 \%$ a mais de residências atendidas com a coleta de esgoto em relação ao decênio anterior. Entretanto, os números ainda estão bem abaixo da média do município que apresentava, em 2010, 92\% de esgoto coletado nas residências, ou seja, a média do distrito do Grajaú ainda se apresenta praticamente com $20 \%$ menor em relação à média da cidade de São Paulo.

Na mesma subprefeitura de Capela do Socorro, os distritos da Cidade Dutra e do Socorro apresentam números bem melhores. Por exemplo, o distrito do Socorro possuía, em 2010, apenas 33 domicílios que não eram ligados a rede de coleta de esgoto. O que resulta num índice extraordinário de $99,8 \%$ de domicílios ligados à rede geral de coleta de esgoto e apenas $0,2 \%$ não conectados a essa rede. 
Tabela 5. Domicílios ligados ou não à rede de esgoto -2010

\begin{tabular}{|c|c|c|c|c|c|}
\hline \multicolumn{6}{|c|}{ Município de São Paulo, Subprefeituras e Distritos Municipais } \\
\hline $\begin{array}{c}\text { Unidades } \\
\text { Territoriais }\end{array}$ & $\begin{array}{l}\text { Total de do- } \\
\text { micílios }\left(^{\star}\right)\end{array}$ & $\begin{array}{l}\text { Ligado à } \\
\text { rede }\end{array}$ & $\begin{array}{l}\text { Não li- } \\
\text { gado }\end{array}$ & $\begin{array}{c}\text { Percentual } \\
\text { Ligado }\end{array}$ & $\begin{array}{l}\text { Percentual } \\
\text { não ligado }\end{array}$ \\
\hline $\begin{array}{l}\text { Município de } \\
\text { São Paulo }\end{array}$ & 3.570 .406 & 3.285 .168 & 285.238 & $92 \%$ & $8 \%$ \\
\hline $\begin{array}{l}\text { Capela do } \\
\text { Socorro }\end{array}$ & 173.050 & 141.154 & 31.896 & $81,6 \%$ & $18,4 \%$ \\
\hline Cidade Dutra & 57.670 & 54.115 & 3.555 & $93,8 \%$ & $6,2 \%$ \\
\hline Grajaú & 102.946 & 74.638 & 28.308 & $72,5 \%$ & $27,5 \%$ \\
\hline Socorro & 12.434 & 12.401 & 33 & $99,8 \%$ & $0,2 \%$ \\
\hline \multicolumn{6}{|c|}{$\begin{array}{l}\left({ }^{*}\right) \text { Total de domicílios MSP: Base Universo do Censo 2010. Dado levantado apenas para os do- } \\
\text { micílios particulares permanentes. } \\
\text { Fonte: IBGE. Censo 2010/SMDU/Dipro. } \\
\text { Elaboração: SILVA, Fabiano Leite. }\end{array}$} \\
\hline
\end{tabular}

Esses números, embora possam apresentar um quadro de melhora, devem ser comparados a outros índices, como o de crescimento de favelas no munícipio de São Paulo e especializados por distritos.

No distrito do Grajaú, segundo dados do Infocidade, o número de domicílios em favelas era de 12.572, em 2008, e passou para 19.388, em 2012, ou seja, considerando esse período, em apenas quatro anos o número de domicílios em favelas no distrito aumentou cerca de $64,88 \%$, enquanto o número de domicílios em favelas na capital passou nesse período de 382.286 domicílios para 393.447 domicílios, e a média da capital para o período ficou em 9,73\% de aumento no número de domicílios em favelas.

Lembrando a importância de comparar e relativizar esses números sobre a coleta de esgotos na cidade de São Paulo, o técnico em geoprocessamento, Jânio Marcos da Secretaria do Verde Meio Ambiente da Prefeitura Municipal de São Paulo, adverte:

Esses números devem ser relativizados. Esses números sobre residências que não possuem coleta de esgoto devem ser bem maiores, já que não leva em conta, por exemplo, habitações irregulares nas áreas de proteção aos mananciais.

Como podemos constatar esses problemas durante o trabalho de campo na Comunidade Sucupira. 
Figura 30. Esgoto a céu aberto na Comunidade Sucupira

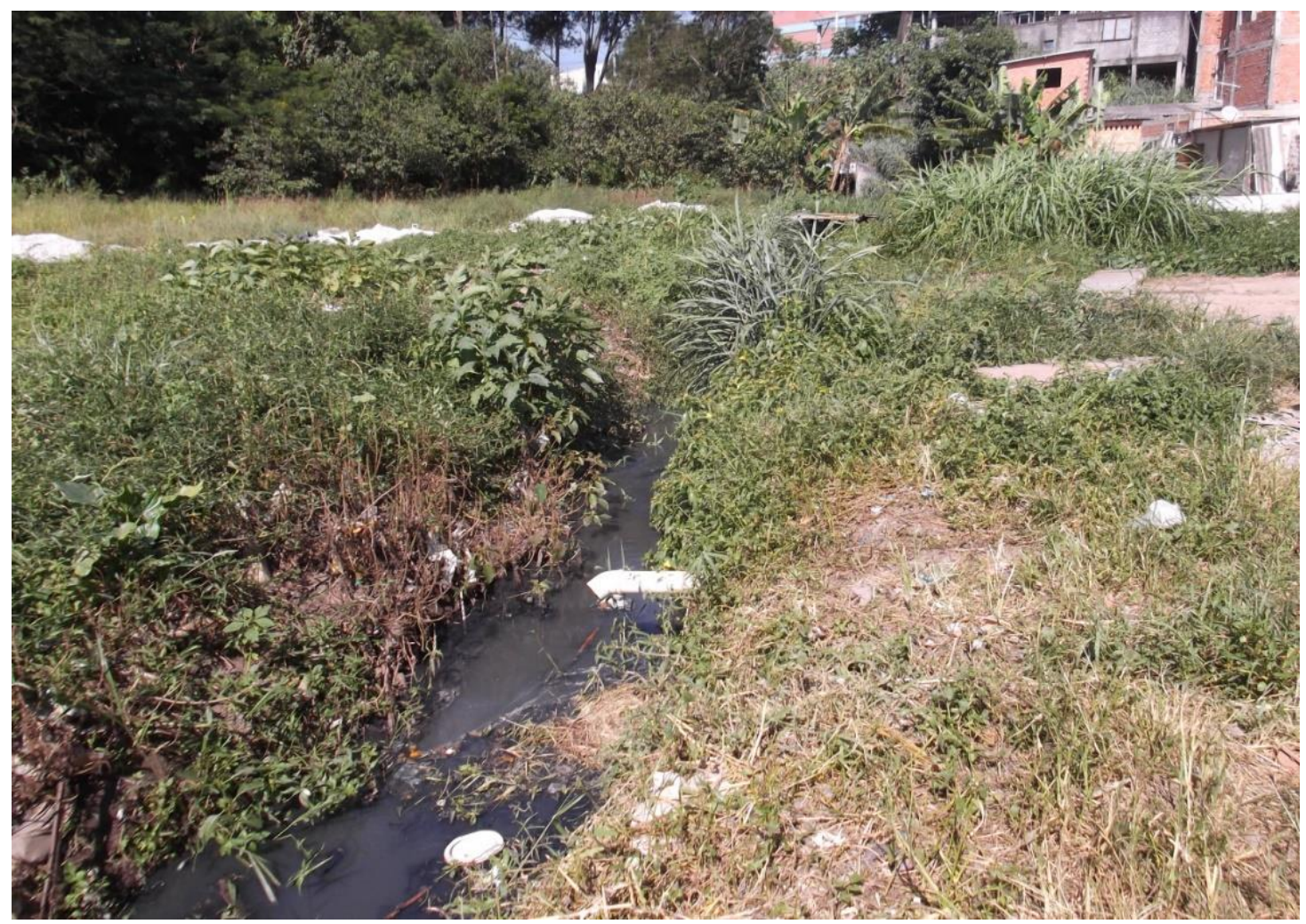

Problemas de coleta de esgoto na favela Sucupira, 30 de abril de 2016. Foto do autor.

Figura 31. Foco de contaminação em córrego da Comunidade Sucupira

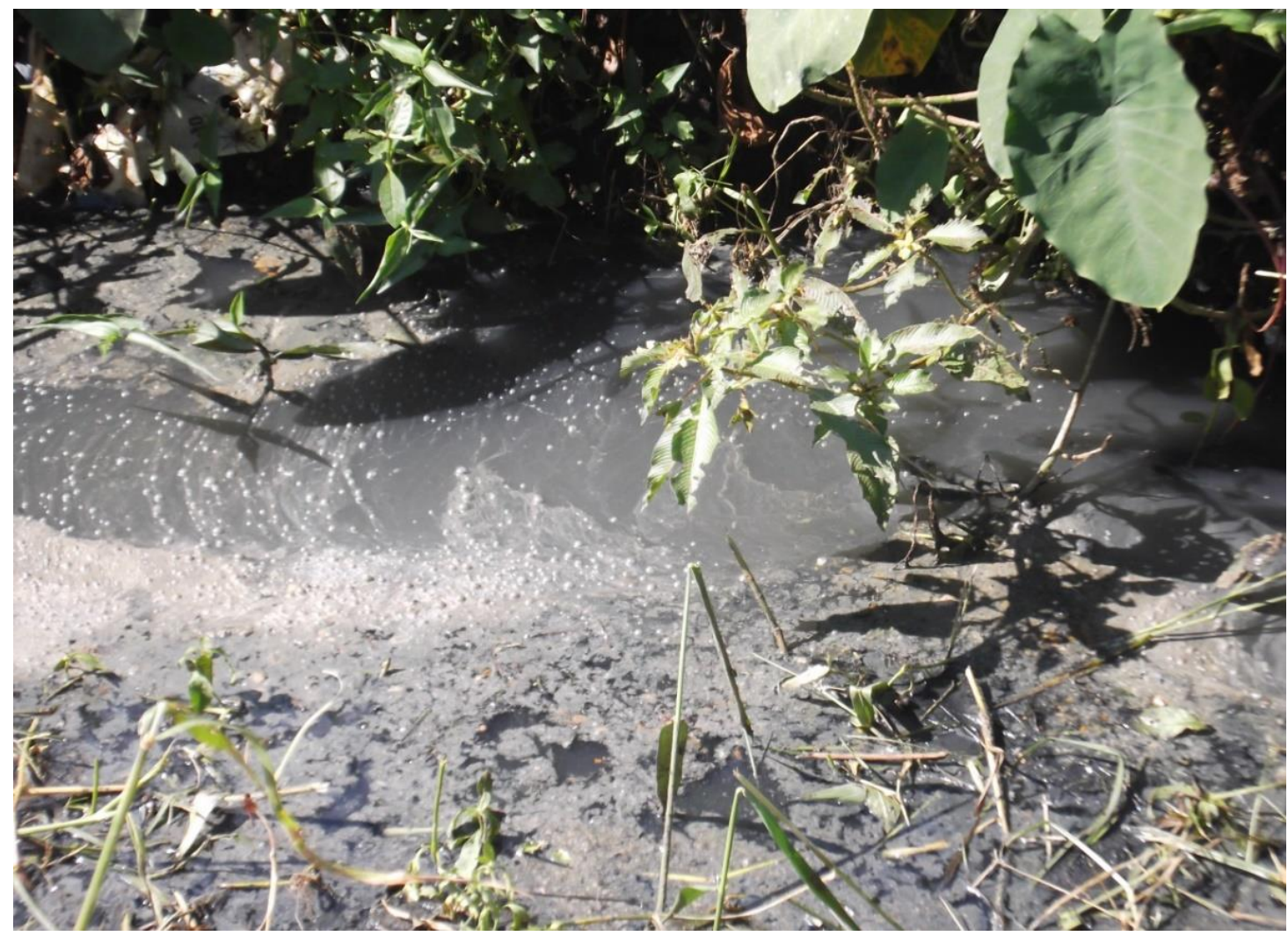

Problemas de coleta de esgoto na favela Sucupira, 30 de abril de 2016. Foto do autor. 
Corrobora para essa análise, o estudo feito por Edilson Carlos do Instituto Trata Brasil:

os dados de cobertura divulgados pelo poder público não levam em conta as moradias irregulares, como as construções feitas em áreas invadidas, favelas e beiras de represa, que são numerosas na capital paulista. Os operadores desse serviço, como é o caso da Sabesp, só publicam os números referentes às áreas regulares, porque, por lei, eles são proibidos de levar a rede de água e coleta a esses locais. (Disponível em: www.fiquemsabendo.com.br/2015/06/194-mil-imoveis-de-sao-paulo-naosao-ligados-a-rede-de-coleta-de-esgotos. Acesso em: fev. 2016).

Além desse grave fato, de se excluir dos dados oficiais as favelas com a crise hídrica mais recente vivida na região metropolitana de São Paulo, outras questões importantes são levantadas e revelados pela reportagem apresentada pela revista Exame de 1/4/2015, na qual é relatado:

A Companhia de Saneamento Básico do Estado de São Paulo (Sabesp) vai reduzir em mais da metade o investimento em coleta e tratamento de esgoto para destinar mais recursos para as obras de enfrentamento da crise hídrica e tentar evitar o colapso no abastecimento na Grande São Paulo. Pela primeira vez em anos, a Sabesp vai investir mais em abastecimento, que atinge quase $100 \%$ da população, do que em esgoto, dos quais $15 \%$ ainda não são coletados e 23\% não são tratados. Entre 2015 e 2016, obras relacionadas à água devem concentrar $65 \%$ dos investimentos [...] Só neste ano, a previsão é aplicar $\mathrm{R} \$ 1,5$ bilhão, $16 \%$ a mais do que o $\mathrm{R} \$ 1,3$ bilhão investido em 2014, quando começou a crise no Cantareira. Por outro lado, os recursos para coleta e tratamento de esgoto cairão $55,7 \%$, de $R \$ 1,9$ bilhão, no ano passado, para R\$843 milhões neste ano. (LEITE, Fabio; AKEL, Stefânia. In: Exame.com, 10 abr. 2015).

$\mathrm{Na}$ mesma reportagem, a ambientalista Marussia Whately do Instituto Socioambiental expõe a importância de a questão do fornecimento de água caminhar junto como o tratamento do esgoto:

Não dá para ter uma distância tão grande entre universalizar a água e cuidar do esgoto, que transmite doença e degrada nossos mananciais. "Temos visto muito investimento em água e pouco em esgoto. Essas duas coisas precisam andar juntas. 
Dessa maneira, a diminuição de investimentos na área de coleta e tratamento de esgotos deve agravar ainda mais a situação, especialmente nas áreas de proteção de mananciais. Se levarmos em conta a crise econômica recente e o ressurgimento de uma onda de grande desemprego, tende a haver um novo crescimento de favelas na cidade, um fenômeno que havia diminuído um pouco seu ritmo de crescimento tanto no município quanto no distrito do Grajaú, conforme os dados mostram.

No final dessa reportagem, a Sabesp questiona os dados do Instituto Trata Brasil, assumindo que eles calculam espaços na cidade onde ela não atende, como as áreas de proteção de mananciais. Isso é uma grande contradição, pois, se ela deseja preservar os mananciais, é justamente nessas áreas em que deveria intensificar o atendimento, pois são nessas áreas que se verificam ocupações recentes, que novamente não vão contar com a infraestrutura necessária, nem constam das estatísticas, como é o caso da Ocupação Anchieta.

\subsection{Contradições recentes na organização do espaço nas áreas de proteção de mananciais: Ocupação Anchieta e parque linear Cantinho do Céu}

As áreas de proteção de mananciais apresentam-se com grandes dilemas, ou seja, grandes questões que envolvem o seu uso e ocupação, gerando contradições em sua organização do espaço.

Em termos de políticas públicas, sempre houve uma contradição evidente, que ficou nítida na área de estudo com a promulgação das primeiras leis de proteção aos mananciais na década de 1970, mais exatamente as Leis no 898 , de 1975, e no 1.172, de 1976, que restringiam diversos usos na tentativa de controlar a ocupação da área. Em contrapartida, concomitantemente uma política habitacional serviu para criar um vetor de ocupação e estimulou o crescimento da área, que foi a construção de um enorme conjunto habitacional, a Cohab Faria Lima ou Bororé, I e II, conforme aponta Uemura: 
Um outro exemplo, que denota o vetor da população pobre para as áreas rurais como inciativa de política pública, é o Conjunto Bororé, construído pela Cohab em 1975 em áreas de mananciais com 1.190 unidades habitacionais, e o Bororé II, com 178 unidades em plena discussão e implementação da Lei de proteção de mananciais.

Na área de estudo, a Península do Ribeirão Cocaia, especialmente em um dos bairros estudados, o Parque Grajaú, centro do bairro que dá o nome ao distrito Grajaú, há um equipamento urbano, o Conjunto residencial Bororé ou Cohab Brigadeiro Faria Lima, que é uma verdadeira síntese das contradições das políticas públicas do período, entre o governo do Estado de São Paulo, governado na época por Paulo Egydio Martins (1975-1979), e a Prefeitura Município de São Paulo, administrada no período da aquisição dos terrenos por Paulo Maluf (1969-1971), e durante a construção por Miguel Colasuonno (1973-1975). Enquanto o Estado promulgava as leis de proteção aos mananciais, a Prefeitura terminava de instalar esse conjunto habitacional dentro da APM, em uma área rural, desprovida de infraestrutura, como disse em entrevista a presidenta da associação de moradores do Parque Grajaú, Cleide, ao se referir como foi a sua infância no conjunto habitacional:

A rua era de terra, sem luz a gente não saía, a gente ficava dentro de casa para não sujar a roupa, para não se machucar porque a rua era de barro, aí foi passando, aí veio as pedrinhas e aí a gente já podia sair para brincar na rua.

Esse conjunto habitacional foi um grande atrativo de população. Outra contradição evidente é criação das leis de proteção aos mananciais e a falta de fiscalização para o cumprimento dessas normas. Como poderia tal fato ser explicado? A explicação baseada nos argumentos da professora Ermínia Maricato parece ser bastante plausível:

A maior tolerância e condescendência em relação à produção ilegal do espaço urbano vem dos governos municipais aos quais cabe a maior parte da competência constitucional de controlar a ocupação do solo [...] O poder de polícia sobre o uso das terras públicas urbanas é exercido de forma discriminatória nos diversos bairros da cidade. Áreas de proteção ambiental, desvalorizadas para o mercado imobiliário, não raramente são priorizadas para ocupação pela população pobre, seja nas favelas ou nos loteamentos irregulares, abertos sob os olhares da condescendente fiscalização. A 
tolerância pelo Estado, em relação à ocupação ilegal, pobre e predatória de áreas de proteção ambiental ou demais áreas públicas, por parte das camadas populares, está longe de significar, o que poderia ser argumentado, uma política de respeito aos carentes de moradia ou aos direitos humanos, já que a população aí se instala, sem contar com qualquer serviço público ou obras de infraestrutura urbana. (MARICATO, 1995, p. 33-34).

Outros dois fatores que também causaram grandes contradições na área de proteção aos mananciais, ainda relacionados à legislação vigente durante um longo período, foi a criação das próprias leis e a falta de incentivo para que a população que possuía chácaras as mantivessem - um incentivo poderia ser isenção ou, no mínimo, redução de IPTU para aqueles que se ocupassem com produção rural na área.

Grande parte disso foi gerado pela não partição popular durante a elaboração das leis de proteção aos mananciais, uma vez que estávamos nesse período em plena ditadura militar, que castrava todos os direitos sociais. Essa política que visava proteger o meio ambiente, esqueceu-se de incorporar o ser humano como ser social nas suas discussões, como produtor e transformador de espaço.

\subsubsection{A Ocupação Anchieta}

A ocupação Anchieta é uma ocupação muito recente, no bairro do Grajaú, em um terreno contíguo à Cohab Brigadeiro Faria Lima. Ela iniciou-se em 29 de junho de 2013, portanto há apenas três anos.

Figura 32. Ocupação Anchieta

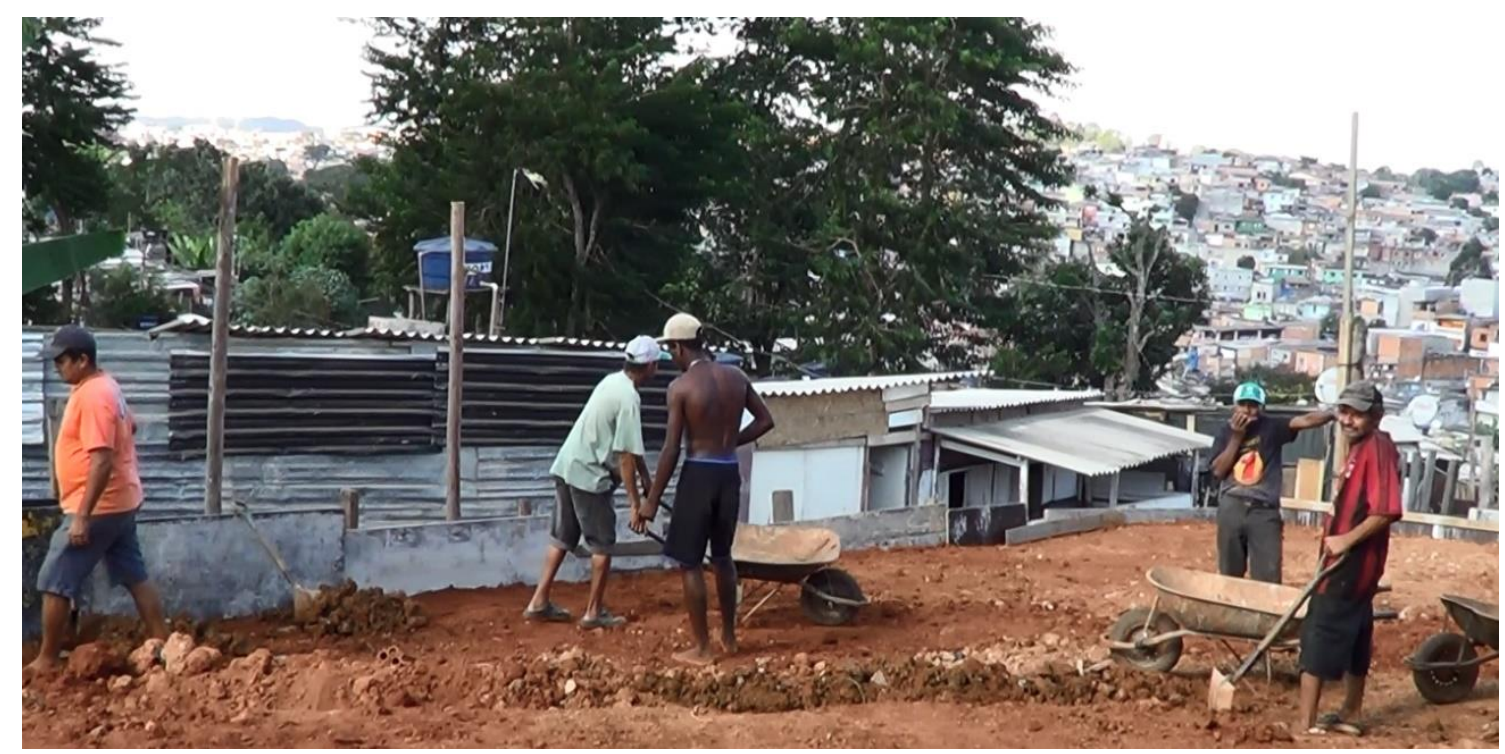

Trabalhadores construindo a sede da Ocupação Anchieta, 29 de maio de 2016. Foto do autor. 
Segundo uma das lideranças da ocupação, Fernando, mais conhecido como Flash:

Essa ocupação aconteceu em um terreno vazio, onde aconteciam depredações contra veículos, e outros vários tipos de violência, então as pessoas resolveram ocupar. No início eram 120 famílias. O pessoal foi porque hoje em dia muita gente não tem moradia, o aluguel está muito caro.

Nesse período ocorreram duas tentativas de reintegração de posse, mas através de várias manifestações, conseguiu-se reverter essas reintegrações. Segundo relato do mesmo entrevistado Fernando Flash:

\begin{abstract}
A maioria das pessoas era no início da própria região, eu cheguei aqui fugindo do aluguel, morava na Cidade Dutra, cheguei aqui na ocupação meio que por acaso. Vi o pessoal que tava encostando as madeiras, eu também tava trazendo umas madeiras, eles perguntaram tá precisando, respondi estou precisando sim de moradia, então pode chegar pra cá. Aí eu encostei umas madeiras. Chegou outro amigo meu que eu já conhecia, e eu fiz um barraco. Daí para a frente chegaram outras pessoas de Guaianases, Itaquera, da M' Boi Mirim, Santo Eduardo (Embu), Tatuapé, de várias regiões, hoje é uma ocupação que já vai para três anos e a região é uma das mais organizadas.
\end{abstract}

Esse fato mostra a solidariedade entre a população mais pobre, já que os diferentes governos ao longo da história ou não tiveram vontade política, ou alguns poucos governos que tiveram algum desejo de encaminhar uma solução para a questão não tiveram condições políticas para tratar dos problemas com relaçãoà questão da moradia. Os trabalhadores viram-se obrigados a resolver esse problema de maneira parcial ou precária para continuar a sobreviver, seja com o modelo de ocupação periférica, casa própria, autoconstrução, loteamento clandestinos, na periferia, seja com o agravamento das questões econômicas e com o desemprego, com a favela, seja mais recentemente em movimentos mais organizados de luta pela moradia que estão espalhados pelas cidade usando a estratégia de ocupação de terrenos na periferia e de prédios nos centros urbanos brasileiros. 
Nos dizeres de Martins, (2011, p. 63), "A tensão daí resultante se mostra na periferia como um embate com a natureza; nos centros com a sociedade e o mercado".

Poderíamos concluir que a população nas periferias ainda enfrenta as restrições a ocupações por causa das leis de proteção aos mananciais, conforme vimos no decorrer deste trabalho.

Um fato que chama a atenção é que o movimento social, segundo Anderson Fernandes:

É um movimento social democrático que luta pela moradia, mas não
apenas pela moradia, pois tem um trabalho social aqui também como o
desenvolvimento de atividade como a capoeira de segunda e quarta feira,
para crianças de $7-17$ anos, e o teatro aos sábados com a tia Ana com
crianças até os 12 anos. Nós estamos evoluindo dessa forma, não só
pensando em moradia, mas em trabalhos sociais e no bem-estar de
nossas crianças.

Esse fato demostra a consciência dos movimentos sociais atualmente, que não basta apenas a casa, é necessário mais que isso. É preciso trazer o urbano, trazer mais vida para essas comunidades por intermédio de atividades artísticas e culturais.

Em relação à questão da consciência das lideranças no que se refere à ocupação de um terreno dentro de uma área de proteção de mananciais, os moradores evidenciam o conflito, porém existe não por culpa deles, e sim devido a toda a problemática da moradia e da questão ambiental. Segundo Anderson Fernandes:

Área de manancial, o governo do Estado quer reflorestar, já a prefeitura pretende construir moradias, aqui onde nós temos bastante pessoas com um refúgio para o aluguel, jovens, homens e mulheres que casam e vivem com a família moram aqui dentro, pessoas que não aguentam mais pagar o aluguel se localizam aqui dentro, essa é a situação que a gente enxerga dessa foram a moradia é primordial aqui dentro, porque não é fácil pagar aluguel.

Esse relato exibe um fato muito importante, bastante diferente do que acontecia até os anos 1970-1980 na área de estudo que era a intervenção estatal com a construção da Cohab, e o modelo de expansão periférico com o sonho da 
casa própria. Isso não significa que esse modelo tenha se esgotado, mas que a situação de parte da classe trabalhadora ainda é tão precária que os trabalhadores não conseguem participar dos programas oficiais de governo, ou devido à demanda não são absorvidos por programas sociais como o Minha Casa Minha Vida (MCMV), mesmo com seus avanços, como pela primeira vez na história haver o financiamento para uma parcela da população a fundo perdido, ou seja, sem retorno de lucro e sem cobrar por isso, nem a Companhia de Desenvolvimento Habitacional Urbano (CDHU) do governo do Estado atende essa demanda por moradias de interesse social, nem a população consegue comprar um terreno em um loteamento irregular ou clandestino em centenas de prestações para construir a casa própria, muito menos as casas para aluguel são capazes de atender essas pessoas extremamente pauperizadas.

E diferentemente das décadas de 1990, o que ocorre agora são ocupações bem mais organizadas, que exigem do governo uma resposta através de uma política habitacional de construção de moradia populares e não simplesmente a permissão para ficar no terreno e construir uma nova favela, o que não parece ser em hipótese alguma o que os movimentos populares querem, neste caso o Movimento da Ocupação Anchieta. Esse pensamento fica claro nas palavras de Flash:

Nós aqui conseguimos negociar a construção de 1.800 moradias, mas no caso, por ser uma área de manancial e ter aqui no terreno duas minas de água, e dos $20 \%$ do terreno para área de compensação ambiental caiu para 1400 moradias, vão ser 15 torres de prédios, cada um com cinco andares. Era para começar em 2016, mas provavelmente não vai começar agora, deve ser feito a partir de 2017 quando a Cetesb aprovar. Há muita burocracia por parte do governo estadual, ele não nos dá apoio e, se você olhar mesmo, eu não vejo moradia nenhuma por parte do governo do Estado que tenha sido construída, quando que o governo Estatual e Municipal tem construído moradia, há mais de vinte anos a gente não vê nada, só tá se construindo ponte, nós a classe pobre não depende só de ponte.

De fato, se observarmos atentamente, os números da produção habitacional do Governo do Estado de São Paulo são pífios, considerando que o Estado de São Paulo possui o segundo orçamento do país, perdendo apenas para a própria União. 
Marques e Rodrigues, utilizando dados de 2009-2013, dão a dimensão do descaso por parte do governo do Estado de São Paulo, que, com o seu programa, o CDHU, comparado-se a produção do mesmo período para a cidade de São Paulo realizada pelo principal programa habitacional do governo federal Minha Casa Minha Vida (MCMV), o CDHU produziu apenas $11,4 \%$ de moradias em relação ao que foi produzido pelo governo federal, corroborando as críticas e a insatisfação dos líderes do movimento da Ocupação Anchieta.

Com efeito, nos últimos quatro anos, o Programa Minha Casa Minha Vida produziu cerca de 105 mil unidades habitacionais $(\mathrm{UH})$, enquanto a CDHU Companhia de Desenvolvimento Habitacional e Urbano, produziu pouco menos de 12 mil unidades habitacionais (UH), parte delas em associação com o próprio governo federal. (MARQUES E RODRIGUES, 2014, p. 337).

Esses números demonstram na verdade que habitação não é uma questão de prioridade para últimos governadores que ocuparam este posto no Estado de São Paulo, e isso se reflete nesse conflito enorme que está ocorrendo nas APMs, em que pese planos de despoluição da represa, remoções, congelamentos, nada disso tem efeito sem resolver a questão habitacional.

A seguir veremos mais uma solução proposta e os seus conflitos gerados nas áreas de proteção aos mananciais, mais especificamente na Península do Ribeirão Cocaia, no bairro Cantinho do Céu.

\subsubsection{O parque linear Cantinho do Céu}

$\mathrm{Na}$ área de estudo, em especial no bairro Cantinho do Céu, ocorreu recentemente uma grande intervenção por parte do Poder Público com a construção do parque linear Cantinho do Céu. Esse parque evidencia uma das maiores contradições que ainda não foram resolvidas pelas políticas públicas: a preservação do meio ambiente e a questão das habitações nesses lugares.

A construção do parque linear prevê que ele seja feito em toda a orla da Península do Ribeirão Cocaia, e por enquanto foi feito uma parte de apenas $1,5 \mathrm{~km}$ da orla da Península. A política possui a ideia de desfazimento, que é um conceito que a prefeitura do município de São Paulo vinha aplicando durante a gestão Kassab, que previa entre outras coisas a remoção de pessoas que encontravam- 
se próximos à borda da represa, conforme foi exposto anteriormente, com as suas consequências, como o que aconteceu na Vila Madeirite, e congelamento de áreas. Entretanto, isso é um pouco difícil, pois como é possível congelar processos sociais e urbanos, que apresentam sempre dinâmicos no espaço sempre em constante movimento? Isso é impossível sem propor alternativas habitacionais, pensando a cidade como um todo e, consequentemente, realizando um amplo debate incorporando as pessoas que moram no lugar onde está sendo feito uma intervenção pontual desse tipo.

A ideia de desfazimento não se demonstrou eficaz, pois não adianta apenas a medida arbitrária de remover as casas. Embora a intenção seja a remoção mínima de população, não foi exatamente isso que aconteceu.

Segundo a líder comunitária Josiane:

\footnotetext{
Foram desapropriadas muitas famílias, que perderam suas raízes, na época do Prefeito Gilberto Kassab, muitas pessoas ganharam qualquer valor e tinham casas grandes e tiveram que comprar casas pequenas de moradias porque foram desapropriados, e muitos hoje moram de aluguel social e muitas vezes atrasam o aluguel, atrasavam muito e os donos pediam as casas e as pessoas tinham que mudar. No governo atual Haddad, não sou de jogar confete, mas deu uma melhorada na questão da moradia, mas o que o governo Haddad fala é que não tem condições ainda de atender com moradia a todo mundo. Está acontecendo invasão em cima de invasão e a coisa está fugindo ao controle social.
}

Corrobora para isso a entrevista de Sandro Mamberti, líder da associação, que disse a respeito das desapropriações para a construção do parque linear, "teve gente que se deu bem que soube negociar, mas teve gente que não soube negociar as desapropriações e se deu muito mal".

Se considerarmos o estudo feito pela própria prefeitura sobre as condições socioeconômicas da população que reside no Cantinho do Céu antes da construção do parque linear, com base nos dados podemos inferir com facilidade que quaisquer intervenções que não fornecessem uma nova residência às pessoas ou condições para que essas podassem comprar outro imóvel, tornaria muitas famílias bem mais vulneráveis do ponto de vista social e ambiental. Basta ver a margem oposta onde 
foi construído o parque onde as casas estão aumentando e chegando novamente dentro das bordas da represa.

Analisando, por exemplo, a renda da população em $2010,74 \%$ da população recebia entre 0-3 salário à mínimos, o que denota uma população com renda muito baixa e que não consegue, historicamente, participar do mercado formal de habitação, portanto quaisquer intervenções teriam que, no mínimo, terem um projeto habitacional com moradias prontas que atendessem a essa parcela da população que foi removida.

Além disso, é em sua maioria predominantemente jovem, $51,71 \%$, conforme mostra a tabela e $82 \%$ da população possui apenas o ensino fundamental completo, e, em qualquer crise, geralmente são os primeiros a serem demitidos devido ao baixo nível de escolaridade e terem mais dificuldade de se recolocarem no mercado de trabalho. Esse cenário faz com que a moradia, mesmo sendo precária e o não pagamento de aluguel, seja a garantia de sobrevivência em momentos mais turbulentos da economia do país, que por vezes acontecem.

Tabela 6. Cantinho do Céu: população segundo faixas etárias

\begin{tabular}{|c|c|c|c|}
\hline \multicolumn{4}{|c|}{ POPULAÇÃO SEGUNDO FAIXA ETÁRIA } \\
\hline Faixa Etária & $N^{\circ}$ Abs. & $\%$ & $\begin{array}{c}\text { \% Jovens, } \\
\text { Adultos e ldosos }\end{array}$ \\
\hline Até 6 anos & 3500 & $12,48 \%$ & \multirow{4}{*}{$51,71 \%$} \\
\hline Entre 7 e 14 anos & 5089 & $18,15 \%$ & \\
\hline Entre 15 e 18 anos & 2248 & $8,02 \%$ & \\
\hline Entre 19 e 25 anos & 3664 & $13,07 \%$ & \\
\hline Entre 26 e 39 anos & 6450 & $23,00 \%$ & \multirow{2}{*}{$43,71 \%$} \\
\hline Entre 40 e 59 anos & 5807 & $20,71 \%$ & \\
\hline 60 anos ou mais & 1017 & $3,63 \%$ & $3,63 \%$ \\
\hline Sem informação & 267 & $0,95 \%$ & - \\
\hline Total & 28042 & $100 \%$ & - \\
\hline
\end{tabular}

Fonte: FRANÇA, E. (Org.); BARDA, M. Entre o céu e a terra: o Cantinho do Céu. Prefeitura Municipal de São Paulo: 2012, p. 111. 
Gráfico 4. Perfil socioeconômico do Cantinho do Céu

Distribuição de Pessoas por Faixa de Idade

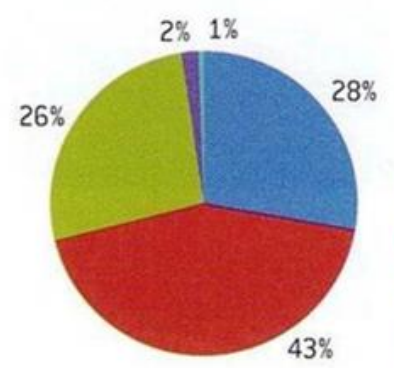

Entre 0 e 14 anos

Entre 15 e 39 anos

Entre 40 e 64 anos

64 anos ou mais

Sem Informação
Renda Familiar Média

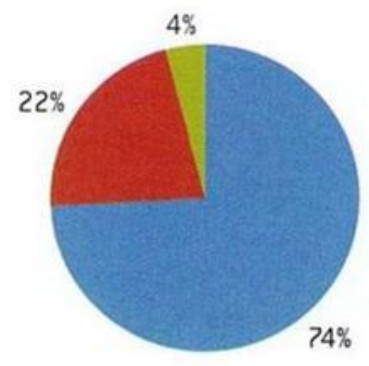

Entre 0 e $3 \mathrm{SM}$

Mais de 3 a 6 SM

Mais de 6 SM

Distribuição de Famílias por $n^{\circ}$ de Componentes

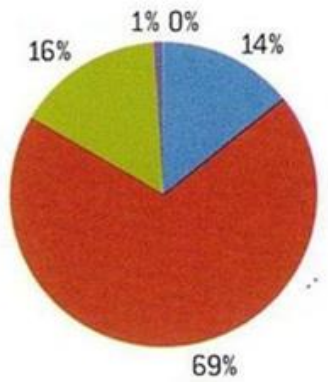

Pessoa só

Familias compostas de 2 a 4 pessoas

Familias compostas de 5 a $?$ pessoas

Familias compostas de 8 a 10 pessoas

Familias compostas de 11 ou mais pessoas

Distribuição de Pessoas por Grau de Escolaridade

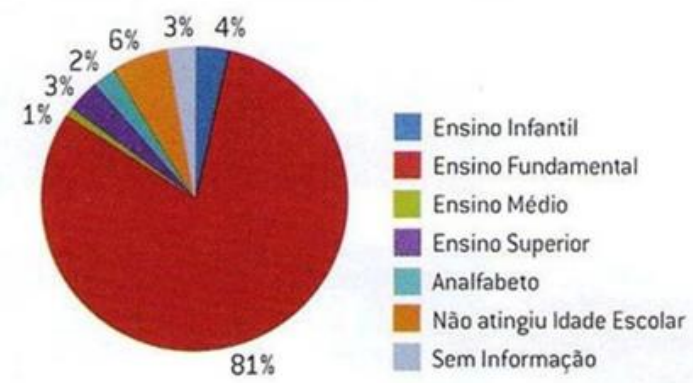

Renda Percapta

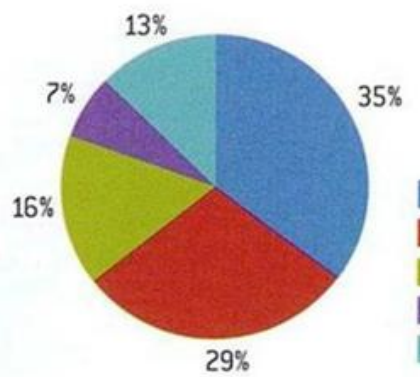

Entre 0 e $0,5 \mathrm{SM}$

Mais 0,5 a $1 \mathrm{SM}$

Mais de 1 a $1,5 \mathrm{SM}$

Mais de 1,5 a 2 SM

Mais de 2SM

Tabela de Distribuição do Chefe da Família X por Sexo

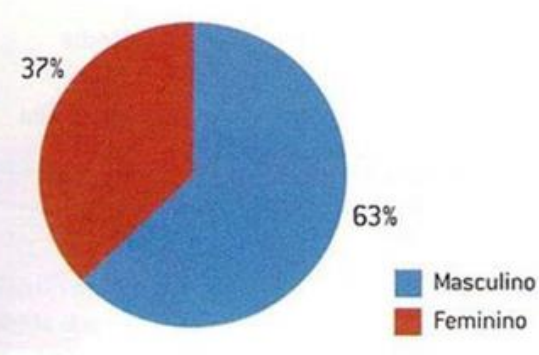

Fonte: PMPS/Sehab, 2010, p. 37.

Fonte: PMSP/Sehab, 2010, p. 37.

O argumento para remoções está baseado na defesa da água e do meio ambiente de uma maneira geral, além da necessidade de áreas de lazer especialmente nas periferias e para as comunidades carentes. 
Figura 33. Parque linear

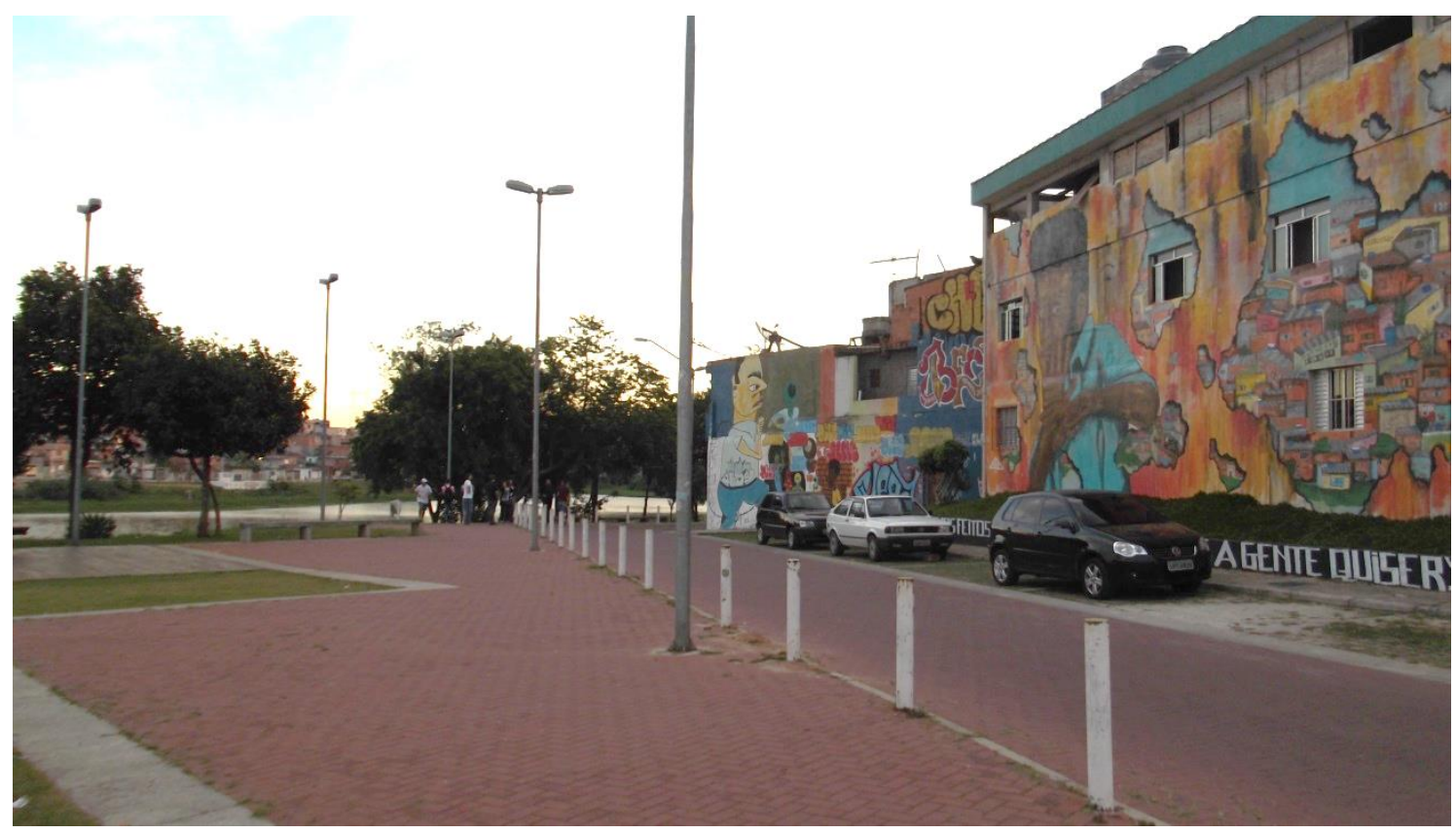

Parque linear, 30 de maio de 2015. Foto do autor.

É evidente que esses argumentos apresentam grande consistência na realidade, mas essa justificativa de proteção ao meio ambiente, de respeito à vida, de necessidade de áreas de lazer serve para remover populações pobres dessas áreas de mananciais, até quando essas possuem a posse da terra, como narrou Ribeiro em um episódio da construção do parque linear na represa Guarapiranga em que foram removidas pessoas de uma área de mananciais já urbanizada, mas muito valorizada, quanto mais na área do Cantinho do Céu em que grande parte das famílias não tem a posse legal da terra.

Podemos, porém, considerar que as consequências dessas ações se realizam ainda mais perversamente àqueles que lutaram por continuar $\mathrm{e}$ uma área mais valorizada, como essa parte da represa do Guarapiranga, já que os esforços contínuos e o enfrentamento da representação do espaço favela foram constantes ao longo da vida daqueles moradores. (Ribeiro, 2015, p. 181).

Além desse primeiro momento da expulsão de moradores com a política de desfazimento, para o desenvolvimento e construção das obras, em um segundo momento, o velho e conhecido processo tão característico do capitalismo, a especulação imobiliária, volta a atuar e a se encarregar de expulsar uma outra parte dos mais pobres. 
Em reportagem do Jornal o Estado de São Paulo, com o título "Depois da Urbanização, imóveis em favelas paulistanas valorizam até 900\%", ao se referir ao processo de urbanização realizado com a construção do parque linear [...]barracos viram "imóveis" e valorizam e os preços disparam em até $900 \%$. No Residencial dos Lagos, que começou o processo de urbanização em 2008, uma casa de três quartos, sala banheiro, que anteriormente era alugada por $R \$ 200$ hoje custa $R \$ 700$. É difícil encontrar aluguel nas favelas por menos de $\mathrm{R} \$ 400$ - valor da bolsaaluguel pago pela Prefeitura para aqueles que são removidos dos barracos em área de risco.

Mas o preço para compra dos imóveis também disparou, chegando a se multiplicar por dez. Casas de quatro a cinco cômodos, que antes da urbanização eram vendidas por $R \$ 15$ mil a $R \$ 20$ mil no Residencial dos Lagos, hoje não são vendidas por menos de $\mathrm{R} \$ 100$ mil, podendo chegar a $R \$ 150$ mil. "E mesmo assim é difícil encontrar quem queira vender porque ninguém vai querer sair daqui”, diz a líder comunitária Vera Lúcia Basilia, integrante do comitê gestor do processo de urbanização local.

Depois da Urbanização, imóveis em favelas paulistanas valorizam até 900\%" Bruno Paes Manso. (Estado de São Paulo, 29/4/2012).

É evidente que houve ganhos, o bairro que é extremamente carente sobre diversos aspectos, como serviços de saúde, de educação, mesmo tendo sido criado um Centro de Educação Unificada (CEU), está unidade chamada CEU Navegantes, pois, segundo a líder comunitária Josiane "embora o CEU tenha sido construído ainda faltam escolas no bairro, pois a demanda é muito grande". Com a construção do parque linear, o bairro ganhou uma grande área de lazer, que, ao que parece, a área foi realmente incorporada por grande parte senão a maioria de seus moradores, inclusive recebe pessoas vinda de outros cantos da cidade para conhecer o parque e a própria represa.

Entretanto, a maior virtude, requalificar áreas de proteção de mananciais para a população, e para a preservação ambiental pode se tornar o seu maior problema, uma vez que os que mais precisam, os mais pobres, acabam sendo expulsos ou pelas obras propriamente ditas, e permanecem sem opção de moradia via mercado formal, ou são expulsos no momento posterior pelo processo de especulação imobiliária, conforme descrito acima. 
Essa é uma das maiores contradições hoje nas áreas de mananciais. Mesmo os projetos que são para melhorar a qualidade de vida da população não conseguem incorporar todas as pessoas pobres residentes do local, e acabam por desencadear outros problemas, entre eles novas ocupações em área tão precárias ou até mais que as anteriores, conforme visto durante a pesquisa.

$\mathrm{O}$ ciclo vicioso de moradia em áreas de fragilidade ambiental repete-se à medida que a verba indenizatória muito baixa e quando muito possibilita apenas a compra da moradia em outra área irregular ou de risco. Essa solução movimenta a máquina da ocupação irregular, das favelas, dos loteamentos clandestinos e da degradação ambiental. Esse tipo de remoção constitui-se um dos principais focos de novas ocupações desmatando novas áreas e ampliando ainda mais a já tão extensa área ocupada por população urbana. A cidade dispersa vai contra os princípios de um urbanismo funcionalista, de cidade compacta, com princípios e preocupações ambientais.

O parque linear em si não é o problema, nem tampouco soluciona o problema. No máximo, ele poderia ser parte da solução, uma vez que desapropriar e fazer o parque pode resolver um problema pontual; porém, sem o encaminhamento adequado para a questão habitacional não há como resolver a situação da área de proteção de mananciais. Também não adianta apenas construir novas casas, conforme nos alerta FERREIRA (2012), ao fazer uma análise profunda sobre os problemas e os avanços do programa do programa Minha Casa Minha Vida, (MCMV), principal programa habitacional do governo em todas as esferas municipal, estadual e, nesse caso, federal desde a extinção do BNH em 1986. Segundo o referido autor, é necessário construir novas cidades no sentido de novas políticas urbanas e, portanto, espaciais, que visem diminuir as injustiças sociais. Não basta construir apenas novas casas, retomando a questão do planejamento urbano-ambiental e que foi abandonado pelos neoliberais, dando lugar aos já tão conhecidos planos de desenvolvimento estratégicos, com soluções pontuais e cirúrgicas para as cidades desconsiderando a sua totalidade. 


\section{Considerações finais}

O problema da ocupação das áreas de proteção de mananciais ainda se apresenta como de difícil solução, dada a conjuntura das mediadas tomadas atualmente. A solução passa, entre outras coisas, por um problema tipicamente geográfico que é a questão das escalas de intervenção, pois são necessárias desde intervenções locais em bairros dentro dos subdistritos até intervenções na cidade e em toda a área metropolitana. Além disso, cabe lembrar as palavras de uma das entrevistadas, Márcia Nascimento, arquiteta da Secretaria Estadual do Meio Ambiente, que afirma: "A palavra-chave para a resolução do problema é integração das políticas metropolitanas", o que nos conduz a uma reflexão de que é necessário haver uma integração entre as políticas públicas entre o Estado e os munícipios, já que quem cria as leis de proteção aos mananciais são as políticas estaduais e quem disciplina o uso e ocupação do solo são os municípios. Entretanto, o que assistimos nos últimos quarenta anos, desde a criação das primeiras leis de proteção aos mananciais no estado de São Paulo, foi um verdadeiro cabo de guerra entre o Estado e o Munícipio de São Paulo.

Apenas a título de exemplo, a área de estudo mostra claramente isso. Concomitantemente à criação das Leis no 896/75 e no 1.172/76 de proteção aos mananciais, erguia-se na Península do Ribeirão Cocaia, no bairro Grajaú, um enorme equipamento habitacional, a Cohab Bororé, que levaria para uma área praticamente vazia do subdistrito do Grajaú com características totalmente rurais cerca de 13 mil pessoas em um distrito que tinha ao todo na época 43.664 no início da década de 1970 e que a população se concentrava a $5 \mathrm{~km}$ antes do local de construção da Cohab, havendo, portanto, um grande vazio entre a área urbanizada e o local de construção deste equipamento habitacional. Para levar essa população para um setor do distrito em que não havia praticamente nada foi necessário implantar infraestrutura e melhorar as estradas de acesso à região, abrindo campo fértil para o processo de especulação imobiliária que já atuava na região, construindo loteamentos clandestinos à revelia da lei.

Atualmente, o uso do solo na área é extremamente complexo, com diversos padrões de ocupação do espaço, como favelas, loteamentos clandestinos, loteamentos regularizados, conjuntos habitacionais, ocupações recentes como a 
Anchieta, e apresenta uma gama de conflitos. As soluções propostas, como a do parque linear, apresentam avanços, tais como a criação de uma área de lazer para uma população extremamente carente; melhora nas condições de urbanização em parte do bairro, organizando ruas e praças. No entanto, apresentou diversos problemas que não foram sanados, pois retirou diversas pessoas da área, conforme a entrevistada Josiane, líder comunitária, que nos relatou: "a comunidade negociou indenização, porém, nem todos conseguiram se realocar no mesmo bairro, desfazendo laços antigos de amizade".

Outro problema foi a grande valorização dos imóveis, o que torna muito difícil para que parte da população se mantenha no local, especialmente quando $74 \%$ da população ganhava em 2009 entre 0-3 salários mínimos. O resultado disso são novas ocupações em áreas ambientalmente tão frágeis quanto a área de que foram removidas. Assim, a construção de parques lineares não são as soluções para áreas de proteção de mananciais, no máximo podem significar parte da solução, na medida em que fizesse parte da composição de uma política maior integrada com outras ações.

Da mesma maneira, também construir habitações apenas também não resolveria o problema, uma vez que habitações sem infraestrutura apenas remetem a processos anteriores como as construções das Cohabs, que agravaram os problemas na cidade ao invés de ajudar a resolvê-los.

O entrevistado Renato Rossetti da Cetesb se opõe severamente a projetos habitacionais em área de proteção de mananciais, "Pode construir em qualquer lugar menos lá, porque não constroem nos jardins", quando perguntado sobre se fosse feita as construções de habitações de interesse social (HIS), em área de mananciais, mesmo se fosse colocada toda infraestrutura, como saneamento básico, diminuindo os efeitos da urbanização, ele levanta outro problema: "Nesses locais são necessárias áreas de recarga, áreas para a água infiltrar, para manter os mananciais vivos, quanto mais impermeabiliza, mais os mananciais vão perder a sua capacidade de recarga e mais difícil vai ser para recuperá-los".

Num quadro de grave crise econômica recente, a questão habitacional que nunca foi resolvida tende a se agravar novamente, consequentemente a tendência é a de aumentar a pressão sobre as áreas vazias e menos valorizadas que em 
geral estão em certas partes da periferia e, em especial, dentro das áreas de mananciais.

A solução para o problema, como foi dito, não está exatamente no lugar, no sentido de intervenções pontuais apenas no local, mas sim no enfrentamento da questão que até agora nenhum governo criou os instrumentos e as condições políticas para esse enfretamento, que é questão fundiária nas grandes cidades brasileiras, em especial São Paulo, onde se localiza a área de estudo.

Ao longo da história, o governo pouco ou nada interviu no mercado de terras, considerando tanto as esferas federal, estadual e municipal, a propriedade privada da terra sempre serviu como instrumento de poder e instrumento de retirada de mais-valia através da renda fundiária em desacordo com a sua função social.

Essa retenção de terras, por parte do mercado privado, "levou à escassez da terra urbanizada e à falta de acesso aos pobres ao mercado imobiliário formal" (GONDIN, 2012, p.115). Nesse sentido, não existe um crescimento desordenado da cidade, que atingiu as áreas de proteção de mananciais, o que existe é o resultado de uma lógica de uma cidade, excludente que até o momento tem apresentado enorme espoliação urbano-ambiental, para a maioria da população.

Resumidamente, a lógica de ocupação da Península do Ribeirão Cocaia foi a lógica de uma metrópole estruturada para atender aos interesses de grandes indústrias, "a industrialização com base em baixos salários determinou muito do ambiente construído" (MARICATO, 2001, p. 41), ao não contabilizar, ou seja, incluir os gastos com habitação nos salários. Essa política condenou parte da população a condições de vida muito precárias em termos de habitação.

Dessa forma, a cidade foi organizada pelo poder público, seja via Estado, seja via Município para a realização do lucro das empresas, e da classe rentista paulistana que vive da especulação imobiliária.

Os resultados espacialmente na área de estudo foram diferentes. No Grajaú, a lógica da ocupação foi comandada pela principal política de habitação estatal dos anos 1970 que foi a construção de conjuntos habitacionais da Cohab, por isso não dá para falar que não houve política pública habitacional para a Península do Ribeirão Cocaia. 
O Parque Residencial Cocaia foi fruto da pura especulação imobiliária através dos loteamentos clandestinos que começaram o seu arruamento já na década de 1970, mas que tiveram seu auge durante os anos 1980 quando foram comercializados, já o resultado espacial no Cantinho do Céu foram as ocupações e a formação de favelas, durante o final dos anos 1980 e especialmente nos anos 1990, quando do agravamento da situação econômica do país e da cidade de São Paulo, com o alto desemprego e o enorme vácuo deixado pelo $\mathrm{BNH}$, que teve a sua extinção em 1986.

As soluções que vieram após essa data, ou seja, o Minha Casa Minha Vida, pelo governo federal, o CDHU, por parte do governo do Estado de São Paulo, e os Cingapura e outros projetos da esfera municipal também se apresentaram ineficientes diante da elevada demanda.

A solução real passa em repensar a cidade como um todo, em combater o processo de especulação imobiliária, em repovoar o centro da cidade - não com lofts, ou flats, que privilegiam moradias individuais, ou que sirvam para aluguel de uma classe mais abastada, privilegiando baixa densidade em uma área dotada de toda infraestrutura e que pode receber mais pessoas - mas com moradia de interesse social, o que Nabil Bonduki chama de "crescer para dentro", adensar áreas que já possuem boa infraestrutura, com quem realmente precisa mais desses serviços por estar muito distante deles e não tem acesso, a população mais carente, tributar com valores cada vez mais altos os imóveis vazios, especialmente os terrenos vazios.

É necessário discutir abertamente com a população em diferentes instâncias a cidade que nós queremos. A primeira possibilidade é continuar com o que temos atualmente, que é uma cidade global, que serve cada vez mais aos interesses do mercado, como tem ocorrido desde a estruturação da metrópole corporativa, que foi modelada para a realização dos lucros e para a fluidez da mercadoria para o grande capital, e que hoje continua a atender a esse capital articulando um espaço para a fluidez da informação das grandes corporações na época da metrópole informacional. Por outro lado, podemos ter uma cidade includente para a realização da vida, dos encontros das pessoas, para a realização pessoal e social do cidadão, com espaços públicos que possam absorver todas as manifestações de cultura da 
metrópole, espaços de moradia dignos em que as pessoas não percam sua vida dentro de ônibus, ou automóveis nos grandes congestionamentos, não habitem em condições sub-humanas, como os cortiços no centro e favelas nas periferias e principalmente nas áreas de proteção de mananciais, em terrenos sem infraestrutura e sem condições de salubridade.

Esse é o debate que se tem que fazer, qual o tipo de cidade que nós queremos. Isso, no limite, significa questionar o modo de produção capitalista, a organização e a produção dos espaços da cidade. Em um sentido mais profundo, questionando esses pressupostos estamos questionando a própria vida presente $\mathrm{e}$ futura que desejamos para nós e para a existência dentro da maior obra humana de todos os tempos, nos dizeres de Lewis Mumford (1965), que é a cidade. 


\section{Referências bibliográficas}

ACSELRAD, Henry. A duração da cidade: sustentabilidade e risco nas políticas urbanas. 2. ed. Rio de Janeiro: Lamparina, 2009.

ALVES, Glória Anunciação. O papel do patrimônio nas políticas de revalorização do espaço urbano. Sripta Nova. Revista Electrónica de Geografia Y Ciencias Sociales, Barcelona, 2008.

ALVES, Humberto Prates da Fonseca. Vulnerabilidade socioambiental na metrópole paulistana: uma análise sócio demográfica das situações de sobreposição espacial de problemas e riscos sociais e ambientais, Revista Brasileira de Estudos de População, São Paulo, v. 23, n. 1, p. 43-59, jan./jun. 2006.

ASSOCIAÇÃO DE MORADORES DO GRAJÁU. Portfólio. São Paulo: s/d.

ASSOCIAÇÃO DE MORADORES DO PARQUE RESIDENCIAL COCAIA INDEPENDENTE. Portfólio. São Paulo: s/d.

AZEVEDO, Aroldo de. A cidade de São Paulo: estudos de geografia urbana. vol II - A Evolução Urbana. São Paulo: Companhia Editora Nacional, 1954.

BARBOSA, M. C. B. Tudo como dantes no quartel de Abrantes: práticas da produção do espaço na cidade de São Paulo, 1890-1930. São Paulo: FAUUSP, 1987.

BERARDI, Maria Helena Petrillo. Santo Amaro. São Paulo: Secretaria Municipal da Cultura, 1984.

BOLTANSKY, Luc; CHIAPELLO, Ėve. O novo espírito do capitalismo. São Paulo: Martins Fontes, 2009.

BONDUKI, Nabil. Origens da habitação social no Brasil: arquitetura moderna, Lei do Inquilinato e difusão da casa própria. 2. ed. São Paulo: Fapesp, 2004. 
. O modelo de desenvolvimento urbano de São Paulo precisa ser revertido. In. Revista de Estudos Avançados, v. 25, n. 71, p. 23-36. São Paulo, 2011.

BRANT, Vinicius. São Paulo: trabalhar e viver. Comissão de Justiça e Paz em São Paulo. São Paulo: Brasiliense, 1989.

BRASIL. Constituição (1988). Constituição da República Federativa do Brasil. Brasília, 1998.

BUENO, Laura Machado de Melo. O saneamento na urbanização de São Paulo. Dissertação de mestrado. São Paulo: FAU-USP, 1994.

BUENO, L. M. M. O Modelo de desenvolvimento urbano processo a ser revertido. Revista de Estudos Avançados, publicada pelo Instituto de Estudos Avançados da Universidade de São Paulo. São Paulo, 2011.

CARLOS, Ana Fani Alessandri. Espaço-tempo na metrópole: a fragmentação da vida cotidiana. São Paulo: Contexto. 2001.

CETESB. Termo de referência para a recuperação ambiental da bacia Billings: consolidação de informações disponíveis e propostas de encaminhamento. São Paulo, 1997.

CHOAY, Françoise. Destinos da cidade europeia: séculos XIX e XX. Revista de Urbanismo e Arquitetura, Salvador, v. 4, set. 2008.

COHN, Amélia. Previdência Social e processo político no Brasil. São Paulo: Moderna. 1981.

DENALDI, Rosana. Políticas de urbanização de favelas: evolução e impasses. Dissertação de Doutorado. São Paulo: FAU-USP, 2003.

FERRARA, L. N. Projetos de reurbanização nas áreas de mananciais em São Bernardo do Campo: a lei específica da Billings possibilita novas soluções urbano-ambientais?. In: II Seminário Nacional sobre Áreas de Preservação Permanente em Meio Urbano: abordagens, conflitos e 
perspectivas nas cidades brasileiras - Anais e Textos completos, v. I, 2012.

. Descompassos entre saneamento e habitação e suas implicações na área de proteção aos mananciais da metrópole paulistana. In: III Seminário Nacional sobre o Tratamento de Áreas de Preservação Permanente em Meio Urbano e Restrições Ambientais ao Parcelamento do Solo, 2014, Belém. Anais APP Urbana 2014: a dimensão ambiental da cidade, 2014.

FERREIRA, João Sette Whitaker (Coord.). Produzir casas ou construir cidades?: desafios para um novo Brasil urbano. São Paulo: Fupam, 2012.

FIX, Mariana. Parceiros da exclusão: duas histórias da construção de uma "nova cidade" em São Paulo: Faria Lima e Água Espraiada. São Paulo: Boitempo, 2001.

. Uma ponte para a especulação - ou a arte da renda na montagem de uma "cidade global", Caderno CRH, Salvador, v. 22, n. 55, p. 41-64, jan/abr. 2009.

FRANÇA, Elizabete (Org.); BARDA, Marisa. Entre o céu e a terra: o Cantinho do Céu. São Paulo: Prefeitura Municipal de São Paulo, 2012.

FUNDAÇÃO SEADE SÃO PAULO. Demográfico: resenha de estatísticas vitais do estado de São Paulo, jan. 2014, ano 14, n. 1.

GONDIM, Linda M. P. Meio ambiente urbano e questão social: habitação popular em áreas de preservação ambiental. Cad. CRH. Salvador, v. 25, n. 64, jan./abr. 2012.

GROSTEIN, Marta Dora. Metrópole e expansão urbana: a persistência de processos "insustentáveis". São Paulo em Perspectiva, São Paulo, v. 1, n. 15, jan./mar. 2001.

HARVEY, D. A liberdade da cidade. Revista Geousp - espaço e tempo. São Paulo, 2009, n. 26, p. 9-17. 
JORNAL DA TARDE. A dúvida os mananciais serão protegidos?. São Paulo. 19 out. 1983.

KOWARICK, Lúcio. Produção do espação urbano e lutas sociais: escritos urbanos. 2. ed. São Paulo: Ed. 34, 2009.

LAGENBUCH Jurgen Richard. A estruturação da Grande São Paulo. Rio de Janeiro: IBGE, 1971.

LEITE, Fabio; AKEL, Stefânia. Sabesp vai investir 55\% menos em esgoto.

Exame.com. 1 o abr. 2015.2 Disponível em:

<http://exame.abril.com.br/negocios/sabesp-vai-investir-55-menos-em-esgoto>.

Acesso em: 28 abr. 2015.

LENCIONI. Mudanças na metrópole de São Paulo (Brasil) e transformações industriais. Revista do Departamento de Geografia da USP. v. 12, 1998.

MANSO, Bruno Paes. Depois de urbanização imóveis em favelas paulistanas valorizam 900\%. Estado de S. Paulo, 29 abar. 2012. Disponível: <http://saopaulo.estadao.com.br/noticias/geral,depois-da-urbanizacao-imoveis-emfavelas-paulistanas-valorizam-ate-900-imp-,866668>. Acesso em: 12 abr. 2014.

MARICATO, Ermínia. Metrópole na periferia do capitalismo: ilegalidade, desigualdade e violência, 1995.

MARICATO, Ermínia. Cidades: alternativas para a crise urbana. Petrópolis: Vozes, 2001.

MARICATO, Ermínia. As ideias fora do lugar e o lugar fora das ideias. In: Arantes, O.; Vainer, C.; Maricato. E. A cidade do pensamento único. 3. Petrópolis: Vozes, 2002.

MARQUES, Eduardo Cesar; BICHIR, Renata Mirandola. Investimentos públicos em infraestrutura urbana e produção da periferia em São Paulo In: Revista Espaço e Debates, n. 42, 2001. 
MARQUES, Eduardo (Org.). A metrópole de São Paulo no século XXI: espaços, heterogeneidades e desigualdades. São Paulo: Unesp, 2014.

MARTINS, Maria Lucia Refinetti. São Paulo, Centro e periferia: A retórica ambiental e os limites da política urbana. In. Revista de Estudos Avançados, v. 25, n. 71, p. 59-72. São Paulo, 2011.

MARTINS, Maria Lucia Refinetti. Lei Federal do Parcelamento do Solo - Tensão e diálogo entre o direito à cidade e o direito urbanístico e ambiental. Revista Fórum de Direito Urbanístico e Ambiental, v. 31, p. 83-91, 2007.

MARTINS, Maria Lucia Refinetti. Moradia e mananciais: tensão e diálogo na metrópole. São Paulo: Fapesp, 2006.

MATOS, Odílon Nogueira de. São Paulo no século XIX: a cidade de São Paulo, vol. 2. São Paulo: Associação dos geógrafos do Brasil,1958.

MOREIRA, Clarice da Costa. A cidade contemporânea entre a tabula rasa e a preservação: cenários para o porto do Rio de Janeiro. São Paulo: Unesp, 2004.

MUMFORD, Lewis. A cidade na história. Belo Horizonte: Itatiaia, 1965.

NOBRE, Eduardo Alberto Cuscé. O ideário urbanístico e a legislação na cidade de São Paulo: do Código de Posturas ao Estatuto da Cidade. IX Seminário de História da Cidade e do Urbanismo. São Paulo: FAU-USP, 2006.

OLIVEIRA, Edílson Luiz de. Projeto Interlagos- $A$ "praia" que faltava a São Paulo: contradições e significado da Inserção de Santo Amaro/Zona Sul na Formação Socioespacial Metropolitana. Tese de Mestrado do Departamento de Geográfica da FFLCH-USP, 1996.

OLIVEIRA, Francisco de. Crítica à razão dualista: o ornitorrinco. São Paulo: Boitempo, 2008. 
OLIVEIRA, Mariana. Veja evolução do salário mínimo desde sua criação, há 70 anos. In Portal G1. Disponível em: <http://g1.globo.com/economia/noticia/2011/02/veja-evolucao-do-salario-minimo-desde-sua-criacao-ha-70anos.html>. Acesso em: 14 de julho de 2015.

OLIVEIRA, Francisco de. O vício da virtude: autoconstrução e acumulação capitalista no Brasil. Novos Estudos. Cebrap, São Paulo, n. 74, 2006. Disponível em: <http://novosestudos.uol.com.br/v1/contents/view/1259>. Acesso em: 10 jan. 2014.

POLLI, Simone Aparecida. Moradia e meio ambiente: os conflitos pela apropriação do território nas áreas de mananciais em São Paulo. Rio de Janeiro: UFRJ/IPPUR, 2010.

PONCIANO, Levino Bairros paulistanos de A a Z. São Paulo: Editora Senac, 2001.

RIBEIRO, Fabiana V. Produção contraditória do espaço urbano e resistências. In Carlos, A. F. A (Org.). Crise urbana. 170-185, São Paulo: Contexto, 2015.

RODRIGUES, Arlete Moyses. Moradias nas cidades brasileiras. 3. ed. São Paulo: Contexto, 1990.

RODRIGUES, Arlete Moyses. SEABRA, Manuel. Habitação e espaço social na cidade de São Paulo. In Boletim Paulista de Geografia, São Paulo, n. 64, 2o semestre de 1986 .

ROSS, Jurandyr; CANIL, Kátia; MOROZ, Isabel. Problemas ambientais nas Áreas de Proteção aos Mananciais na Região Metropolitana de São Paulo. Revista do Departamento de Geografia. São Paulo, n. 7, 1994.

SACHS, Céline. São Paulo: Políticas e habitação popular. São Paulo: Edusp,1999.

SAMPAIO, Ruth Amaral de; PEREIRA, Paulo Cezar Xavier. Habitação em São Paulo. Revista de Estud. Av., vol. 17, n. 48. São Paulo, maio/ago. 2003.

SANTOS, Milton. Pobreza urbana. São Paulo: Hucitec, 1979. 
O espaço do cidadão. São Paulo: Nobel, 1987a.

Metamorfoses do espaço habitado. São Paulo: Hucitec, 1987b.

. Metrópole corporativa fragmentada: O Caso de São Paulo. São Paulo: Nobel, 1990.

. A urbanização brasileira. São Paulo: Hucitec, 1998.

. Técnica espaço e tempo. São Paulo: Hucitec, 2004.

SCARLATO, Francisco Capuano. Revitalização do Centro Antigo: o Espaço da Memória de São Paulo. In. CARLOS, Ana Fani Alessandri; CARRERAS, Carles. (Org.). Urbanização e mundialização: estudos sobre a metrópole. São Paulo: Contexto, 2005. v.1, p. 130-136.

SEABRA, Odete. Os meandros dos rios nos meandros do poder: o processo de valorização dos rios e das várzeas do Tietê e do Pinheiros na cidade de São Paulo. São Paulo, 1987. Tese de doutoramento apresentada à FFLCHUSP.

SEMPLA. São Paulo: Crise e mudança. São Paulo: PMSP. Sempla/Brasiliense,1990.

SICSÚ, João. Salário mínimo na ditadura e hoje. In Carta Capital, 29 abr. 2014. Disponível em: <www.cartacapital.com.br/economia/salario-minimo-naditadura-e-hoje-643.html>. Acesso em: 12 de junho de 2015.

SILVA, Fabiano Leite da. As transformações urbanas e os problemas ambientais em uma área de mananciais: o Parque Residencial Cocaia e o Parque Recanto Cocaia. (Trabalho de Graduação Individual) São Paulo, FFLCH-USP, 2001.

SILVA, Eliane Alves da. Governar o ingovernável: gestão da irregularidade urbana em áreas de mananciais em São Paulo. 2011.

SILVA, M. O. da. S. Política habitacional brasileira: verso e reverso. São Paulo: Cortez Editora, 1989. 
SILVA, Vanildo Luís da. Cingapura: a espacialidade do Programa Habitacional do Município de São Paulo na década de noventa do século XX. Tese de Mestrado. São Paulo, 2003.

SILVEIRA, MARIA LAURA. Concretude territorial, regulação e densidade normativa. Revista Experimental. n. 2. São Paulo: Laboplan, 1997.

SÓCRATES, Jodete; GROSTEIN, Marta; TANAKA, Marta. A cidade invade as águas: qual é a questão dos mananciais?. São Paulo: FAU-USP, 1985.

SPÓSITO, MARIA DA ENCARNAÇÃO. Cidade e campo: relações e contribuições entre o urbano e o rural. São Paulo: Expressão popular, 2006.

UEMURA, Margareth Matiko. Programa Guarapiranga: alternativa para a proteção dos mananciais?. Campinas, 2000 (dissertação de mestrado).

VENTURI, Luiz Antônio Bittar. Tristes Mananciais. In CARLOS, Ana Fani Alessandri; OLIVEIRA, Ariovaldo Umbelino de (Org.). Geografias de São Paulo: a metrópole do século XXI. São Paulo: Contexto, 2004.

WHATELY, Marussia; SANTORO, Paula; DIAS, Telma Stephan. Os mananciais são menos urbanizados do que se imagina. In: WHATELY, Marussia; SANTORO, Paula Freire; FERRARA, Luciana Nicolau; BAJESTEIRO, Fernanda Blauth (Orgs.). Mananciais: uma nova realidade?. São Paulo: Instituto Socioambiental, 2008, p. 129-158.

WHATHELY, Marussia.; FERRARA, Luciana Nicolau.; SANTORO, Paula Freire. Mananciais: diagnóstico e políticas habitacionais. São Paulo: Instituto Socioambiental, 2009.

VILAÇA, Flávio. São Paulo: segregação urbana e desigualdade. Revista de Estud. Av., abr. 2011, v. 25, n. 71, p. 37-58. 


\section{Anexos}

Leis de proteção aos mananciais

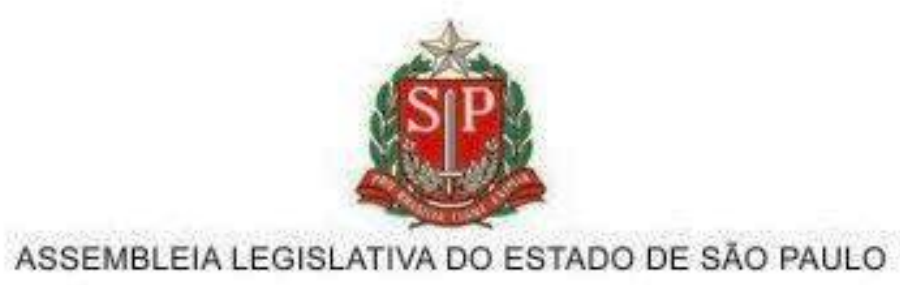

\section{LEI № 898, DE 18 DE DEZEMBRO DE 1975}

Disciplina o uso do solo para proteção dos mananciais, cursos e reservatórios de água e demais recursos hídricos de interesse da Região Metropolitana da Grande São Paulo.

\section{O GOVERNADOR DO ESTADO DE SÃO PAULO;}

Faço saber que a Assembléia Legislativa decreta e eu promulgo a seguinte lei:

Artigo $1^{\circ}$ - Esta lei disciplina o uso do solo para a proteção dos mananciais, cursos e reservatórios de água e demais recursos hídricos de interesse da Região Metropolitana da Grande São Paulo, em cumprimento ao disposto nos incisos II e III do artigo $2^{\circ} \mathrm{e}$ inciso VIII do artigo $3^{\circ}$ da Lei Complementar n. 94, de 29 de maio de 1974.

Artigo $2^{\circ}$ - São declaradas áreas de proteção e, como tais reservadas, as referentes aos seguintes mananciais, cursos e reservatórios de água e demais recursos hídricos de interesse da Região Metropolitana da Grande São Paulo:

I - reservatório Billings;

II - reservatórios do Cabuçu, no rio Cabuçu de Cima, até a barragem no Município de Guarulhos;

III - reservatórios da Cantareira, no rio Cabuçu de Baixo, até as barragens no Município de São Paulo;

IV - reservatório do Engordador, até a barragem no Município de São Paulo;

V - reservatório de Guarapiranga, até a barragem no Município de São Paulo;

VI - reservatório de Tanque Grande, até a barragem no Município de Guarulhos;

VII - Rios Capivari e Monos, até a barragem prevista da SABESP, à jusante da confluência do rio Capivari com o Ribeirão dos Campos, no Município de São Paulo;

VIII - Rio Cotia, até a barragem das Graças, no Município de Cotia;

IX - Rio Guaió, até o cruzamento com a Rodovia São Paulo-Mogi das Cruzes, na divisa dos Municípios de Poá e Suzano;

X - Rio Itapanhaú, até a confluência com o Ribeirão das Pedras, no Município de Biritiba Mirim;

XI - Rio Itatinga, até os limites da Região Metropolitana;

XII - Rio Jundiaí, até a confluência com o rio Oropó, exclusive, no Município de Mogi das

Cruzes;

XIII - Rio Juquerí, até a barragem da SABESP, no Município de Franco da Rocha;

XIV - Rio Taiaçupeba, até a confluência com o Taiaçupeba Mirim, inclusive, na divisa dos 
Municípios de Suzano e Mogi das Cruzes;

XV - Rio Tietê, até a confluência com o rio Botujuru, no Município de Mogi das Cruzes; XVI - Rio Jaguari, afluente da margem esquerda do rio Paraíba, até os limites da Região

Metropolitana;

XVII - Rio Biritiba, até a sua foz;

XVIII - Rio Juquiá, até os limites da Região Metropolitana.

Artigo $3^{\circ}$ - As áreas de proteção de que trata esta lei corresponderão, no máximo, às de drenagem referentes aos mananciais, cursos, reservatórios de água e demais recursos hídricos especificados no artigo $2^{\circ}$.

Parágrafo único - Nas áreas de proteção, os projetos e a execução de arruamentos, loteamentos, edificações e obras, bem assim a prática de atividade agropecuárias, comerciais, industriais e recreativas dependerão de aprovação prévia da Secretaria dos Negócios Metropolitanos e manifestação favorável da Secretaria de Obras e Meio Ambiente, mediante parecer da Companhia Estadual de Tecnologia de Saneamento Básico e de Defesa do Meio Ambiente - CETESB, quanto aos aspectos de proteção ambiental sem prejuízo das demais competências estabelecidas na legislação em vigor para outros fins. Artigo $4^{\circ}$ - As atividades mencionadas no parágrafo único do artigo anterior, se exercidas sem licenciamento e aprovação da Secretaria dos Negócios Metropolitanos, com inobservância desta lei, ou em desacordo com os projetos aprovados poderão determinar a cassação do licenciamento, se houver, e a cessação compulsória da atividade ou o embargo e demolição das obras realizadas, a juízo da Secretaria dos Negócios Metropolitanos, sem prejuízo da indenização, pelo infrator, dos danos que causar.

Artigo $5^{\circ}$ - As áreas de proteção referidas no artigo $2^{\circ}$ serão delimitadas por lei, que poderá estabelecer, nos seus limites, faixas ou áreas de maior ou menor restrição, conforme o interesse público o exigir.

Parágrafo único - As faixas ou áreas de maior restrição, denominadas de primeira categoria, abrangerão, inclusive, o corpo de água, enquanto que as demais denominadas de segunda categoria, serão classificadas na ordem decrescente das restrições a que estarão sujeitas.

Artigo $6^{\circ}$ - Nas áreas de proteção, o licenciamento das atividades e a realização das obras, referidos no parágrafo único do Artigo $3^{\circ}$ desta lei, ficarão sujeitos às seguintes exigências: I - destinação e uso da área perfeitamente caracterizados e expressos nos projetos e documentos submetidos à aprovação;

II - apresentação, nos projetos, de solução adequada para a coleta, tratamento e destino final dos resíduos sólidos, líquidos e gasosos produzidos pelas atividades que se propõem a exercer ou desenvolver nas áreas;

III - apresentação nos projetos, de solução adequada, relativamente aos problemas de erosão e de escoamento das águas, inclusive as pluviais;

$\S 1^{\circ}$ - O licenciamento das atividades hortifrutícolas independerá de projetos, desde que o documento submetido à aprovação contenha os demais requisitos previstos neste artigo. $\S 2^{\circ}$ - O licenciamento de atividades e a aprovação de projetos por quaisquer outros órgãos públicos dependerá de aprovação prévia da Secretaria dos Negócios Metropolitanos e manifestação da Secretaria de Obras e Meio Ambiente, mediante parecer da Companhia de 
Tecnologia de Saneamento Básico e de Defesa ao Meio Ambiente - CETESB, relativamente ao cumprimento dos incisos I a III e $\S 1^{\circ}$ deste artigo.

$\S 3^{\circ}$ - Dos documentos de aprovação constará, obrigatoriamente, que o uso da área só será admitido em conformidade com esta lei.

Artigo $7^{\circ}$ - Os órgãos e entidades, responsáveis por obras públicas a serem executadas nas áreas de proteção, deverão submeter previamente, os respectivos projetos à Secretaria dos Negócios Metropolitanos que estabelecerá os requisitos mínimos para a implantação dessas obras, podendo acompanhar sua execução.

Artigo $8^{\circ}$ - Nas áreas ou faixas de maior restrição denominadas de primeira categoria, somente serão permitidas atividades recreativas e a execução de obras ou serviços indispensáveis ao uso e aproveitamento do recurso hídrico, desde que não coloquem em risco a qualidade da água.

$\S 1^{\circ}$ - As faixas de primeira categoria, observadas as normas desta lei, poderão ser computadas no cálculo das áreas reservadas para sistemas de recreio em loteamentos. $\S 2^{\circ}$ - Vetado.

Artigo $9^{\circ}$ - Na elaboração, implantação e adequação dos planos de urbanização e desenvolvimento, a serem executados na Região Metropolitana da Grande São Paulo, a Secretaria dos Negócios Metropolitanos observará o disposto nesta lei.

Artigo 10 - Em cada área de proteção, a Secretaria dos Negócios Metropolitanos aplicará as medidas necessárias à adaptação das urbanizações, edificações e atividades existentes às disposições desta lei.

Parágrafo único - As urbanizações, edificações e atividades, existentes ou exercidas anteriormente a esta lei, gozarão de prazo adequado para se adaptarem às suas exigências ou procederem à sua transferência para outro local e, na impossibilidade de o fazerem, poderão ser suprimidas mediante indenização ou desapropriação.

Artigo 11 - As restrições a serem estabelecidas em lei e correspondentes as áreas de proteção a que se refere o Artigo $2^{\circ}$, sem prejuízo da legislação em vigor para outros efeitos, constarão de normas relativas a:

I - formas de uso do solo permitidas e as características de sua ocupação e aproveitamento; II - condições mínimas para parcelamento do solo e para a abertura de arruamentos; III - condições admissíveis de pavimentação e impermeabilização do solo;

IV - condições de uso dos mananciais, cursos e reservatórios de água, obedecidos a classificação e o enquadramento previstos em leis e regulamentos;

$\mathrm{V}$ - formas toleráveis de desmatamento nas áreas de proteção;

VI - condições toleráveis para a movimentação de terras nas áreas de proteção;

VII - ampliação e aumento de produção dos estabelecimentos industriais, localizados nas áreas de proteção que possam oferecer riscos à qualidade dos recursos hídricos;

VIII - exigências a serem cumpridas pelas indústrias existentes ou em construção nas áreas de proteção, e o plano de remanejamento das que nelas não puderem permanecer; IX - emprego de defensivos e fertilizantes e prática de atividades hortifrutigranjeiras, que deverão ser limitadas às formas que não contribuam para a deterioração dos recursos hídricos;

$\mathrm{X}$ - condições, e limites quantitativos de produtos nocivos que poderão ser armazenados 
nas áreas de proteção, sem riscos para a qualidade dos recursos hídricos;

XI - condições de passagem de canalizações que transportem substâncias consideradas nocivas às áreas de proteção;

XII - condições de coleta, transporte e destino final de esgotos e resíduos sólidos, nas áreas de proteção;

XIII - condições de transporte de produtos considerados nocivos.

Artigo 12 - As restrições a que se refere o artigo anterior serão fixadas em conformidade com as normas desta lei e com base em critérios de proteção ao meio ambiente, fornecidos pela Secretaria de Obras e Meio ambiente, através da Companhia Estadual de Tecnologia de Saneamento Básico e da Defesa do Meio Ambiente - CETESB, e de uso do solo, fornecidos pela Secretaria dos Negócios Metropolitanos.

Artigo 13 - Os infratores das disposições desta lei e respectivos regulamentos ficam sujeitos à aplicação das seguintes sanções, sem prejuízo de outras estabelecidas em leis especiais:

I - advertência, com prazo a ser estabelecido em regulamento, para a regularização da situação nos casos de primeira infração, quando não haja perigo iminente à saúde pública; II - multa de Cr\$100,00 (cem cruzeiros) a Cr\$ 5.000,00 (cinco mil cruzeiros) por dia, tendo-se em vista o patrimônio do agente infrator, localizado na área de proteção, se não efetuada a regularização dentro do prazo fixado pela Administração:

a) pela execução de arruamento, loteamento, edificação ou obra, sem aprovação prévia da Secretaria dos Negócios Metropolitanos;

b) pela prática de atividades agropecuárias, comerciais, industriais e recreativas, sem aprovação prévia da Secretaria dos Negócios Metropolitanos;

c) pela execução de arruamento, loteamento, edificação ou obra e pela prática de atividades agropecuárias, comerciais, industriais e recreativas em desacordo com os termos da aprovação ou com infração das disposições desta lei e respectivos regulamentos; III - interdição, nos casos de iminente perigo à saúde pública e nos de infração continuada; IV - embargo e demolição da obra ou construção executada sem autorização ou aprovação, ou em desacordo com os projetos aprovados, quando a sua permanência ou manutenção contrariar as disposições desta lei ou ameaçar a qualidade do meio, ambiente, respondendo o infrator pelas despesas a que der causa.

$\S 1^{\circ}$ - As medidas previstas neste artigo serão aplicadas pela Secretaria dos Negócios Metropolitanos.

$\S 2^{\circ}$ - As penalidades de interdição, embargo ou demolição poderão ser aplicadas sem prejuízo daquelas objeto dos incisos I e II deste artigo.

$\S 3^{\circ}$ - O valor da multa prevista no inciso II deste artigo será de Cr\$100,00 (cem cruzeiros), a Cr\$500,00 (quinhentos cruzeiros) por dia no caso de atividades hortifrutícolas.

$\S 4^{\circ}$ - O valor da multa prevista no inciso II deste artigo e em seu parágrafo $3^{\circ}$ será automaticamente reajustado mediante a aplicação dos coeficientes de atualização monetária de que trata o Artigo $2^{\circ}$ da Lei Federal n. 6.205, de 29 de abril de 1975. Artigo 14 - A aplicação de sanções às infrações ao disposto na presente lei, quando ocorrer poluição também do meio ambiente, não impedirá a incidência de outras penalidades por 
ação da Companhia Estadual de Tecnologia de Saneamento Básico e de Defesa do Meio Ambiente - CETESB, nos termos da legislação estadual sobre proteção do meio ambiente do Estado de São Paulo, contra agentes poluidores.

Artigo 15 - O produto da arrecadação das multas decorrentes da infração previstas nesta lei constituirá receita do Fundo Metropolitano de Financiamento e Investimento, quando aplicadas pela Secretaria dos Negócios Metropolitanos, cabendo a responsabilidade pela cobrança à instituição do Sistema de Crédito do Estado, encarregada de administrá-lo. Artigo 16 - Da aplicação das sanções previstas nesta lei caberá recurso ao Secretário dos Negócios Metropolitanos.

Artigo 17 - Esta lei será regulamentada dentro de 180 (cento e oitenta) dias, contados de sua publicação.

Artigo 18 - Esta lei entrará em vigor na data de sua publicação.

Palácio dos Bandeirantes, 18 de dezembro de 1975.

PAULO EGYDIO MARTINS

Francisco Henrique Fernando de Barros

Secretário de Obras e do Meio Ambiente

Roberto Cerqueira Cesar

Secretário Extraordinário dos Negócios Metropolitanos

Publicada na Assessoria Técnico-Legislativa, aos 18 de dezembro de 1975.

Nelson Petersen da Costa

Diretor Administrativo - Subst. 


\section{LEI № 1.172, DE 17 DE NOVEMBRO DE 1976}

Delimita as áreas de proteção relativas aos mananciais, cursos e reservatórios de água, a que se refere o artigo $2^{\circ}$ da Lei Estadual $n^{\circ} 898,18$ de dezembro de 1975, estabelece normas de restrição do uso do solo em tais áreas e dá providências correlatas

\section{O GOVERNADOR DO ESTADO DE SÃO PAULO:}

Faço saber que a Assembléia Legislativa decreta e eu promulgo a seguinte lei:

Art. $1^{\circ}$ - Ficam delimitadas, como áreas de proteção, as contidas entre os divisores de água a que se refere o artigo $2^{\circ}$ da Lei Estadual $n^{\circ}$ 898, de 18 de dezembro de 1975, conforme lançamento gráfico constante de coleção de cartas planialtimétricas, em escalas de 11:10.000, do levantamento aerofotogramétrico do Sistema Cartográfico Metropolitano, efetuado em 1974, registrado no Estado Maior das Forças Armadas, sob no 5/74, e cujos originais serão autenticados e depositados na Secretaria dos Negócios Metropolitanos.

Art. $2^{\circ}$ - Nas delimitações de que trata o artigo anterior, constituem áreas ou faixas de $1^{\circ}$ categoria ou de maior restrição:

I - os corpos de água:

II - a faixa de 50 metros de largura, medida em projeção horizontal, a partir da linha de contorno correspondente ao nível de água máximo dos reservatórios públicos, existentes e projetados;

III - a faixa de 20 metros de largura, medida em projeção horizontal, a partir dos limites do álveo, em cada uma das margens dos rios referidos no artigo $2^{\circ}$ da Lei Estadual $n^{\circ} 898$, de 18 de dezembro de 1975 , e das de seus afluentes primários, bem como em cada uma das margens dos afluentes primários dos reservatórios públicos, existentes e projetados;

IV - as faixas definidas no artigo $2^{\circ}$ e sua alínea "a" da Lei Federal n 4.771, de 15 de setembro de 1965, referentes ás margens dos demais cursos de água;

$\mathrm{V}$ - as áreas cobertas por mata e todas as formas de vegetação primitiva;

VI - as áreas com quota inferior a 1,50 metros, medidas a partir do nível máximo dos reservatórios públicos existentes e projetados, e situados a uma distância mínima inferior a 100 metros das faixas de que tratam os incisos II e III deste artigo; 
VII - as áreas onde a declividade média for superior a $60 \%$, calculada a intervalos de 100 metros a partir do nível de água máximo dos reservatórios públicos existentes e projetados, e dos limites do álveo dos rios, sobre as linhas de maior declive.

Parágrafo único - Consideram-se afluentes primários:

1. os cursos de água diretamente tributários dos reservatórios públicos, existentes e projetados, e dos rios citados no artigo $2^{\circ}$ da Lei Estadual $n^{\circ} 898$, de 18 de dezembro de 1975.

2. O curso de água diretamente tributário, resultante da confluência de dois ou mais rios, considerando-se, também, seu prolongamento, o rio formador que tiver maior área de drenagem.

Art. $3^{\circ}$ - Constituem áreas ou faixas de $2^{\circ}$ categoria, ou de menor restrição, aquelas situadas nas áreas de proteção delimitadas no artigo $1^{\circ}$ e que não se enquadrem nas de $1^{\circ}$ categoria, discriminadas no artigo $2^{\circ}$.

Art. $4^{\circ}$ - As áreas ou faixas de $2^{\circ}$ categoria são assim classificadas:

I - áreas ou faixas de Classe A;

II - áreas ou faixas de Classe B;

III - áreas ou faixas de Classe C;

Art. $5^{\circ}$ - São áreas ou faixas de Classe A:

I - as áreas arrudas e ocupadas com densidade demográfica bruta superior a 30 habitantes por hectare, estabelecidas com base nas fotos e cartas planialtimétricas do levantamento aerofotogramétrico do Sistema Cartográfico Metropolitano, mencionado no artigo $1^{\mathrm{o}}$;

II - as demais áreas arrudas, constante do levantamento aerofotogramétrico, contíguas ás áreas ou faixas definidas no inciso I.

$\S 1^{\circ}$ - O cálculo das densidades a que se refere o inciso I será feito considerando-se:

1. com base territorial mínima de cálculo, as quadrículas com área de 1 hectare, resultantes da subdivisão em 100 partes iguais, das quadrículas formadas pelas coordenadas topográficas representadas nas cartas planialtimétricas em escalas 1:10.000 do Sistema Cartográfico Metropolitano, mencionado no artigo $1^{\circ}$;

2. a ocupação média de 4,3 ocupantes equivalentes por edificação. 
$\S 2^{\circ}$ - Para efeito do disposto nos incisos II e III, são consideradas contíguas as áreas cujos pontos mais próximos distem, entre si, de no máximo 100 metros.

Art. $6^{\circ}$ - São áreas ou faixas de Classe $\mathrm{B}$ as contíguas às de Classe $\mathrm{A}$, delimitadas mediantes a aplicação dos critérios constantes do Quadro I, anexo a esta lei.

Art. $7^{\circ}$ - Constituem áreas ou faixas de Classe $\mathrm{C}$ as não compreendidas entre as Classe $\mathrm{A}$ e B.

Art. $8^{\circ}$ - As águas dos mananciais, cursos reservatórios de água e demais recursos hídricos a que se refere o artigo $2^{\circ}$ da Lei Estadual $n^{\circ}$ 898, de 18 de dezembro de 1975, destina-se, prioritariamente, ao abastecimento de água.

$\S 1^{\circ}$ - permitida a utilização das águas para o lazer, sob controle, desde que não seja prejudicado o uso referido no "caput" deste artigo.

$\S 2^{\circ}$ - As águas poderão ainda ser utilizadas para irrigação de hortaliças e geração de energia, desde que não sejam prejudicados os usos de que tratam o "caput" e o $\S 1^{\text {o desde }}$ artigo.

Art. $9^{\circ}$ - Nas áreas ou faixas de $1^{\mathrm{a}}$ categoria ou de maior restrição, somente são permitidos os seguintes usos e atividades

I - pesca;

II - excursionismo, excetuado o campismo;

III - natação;

IV - esportes náuticos;

$\mathrm{V}$ - outros esportes ao ar livre, que não importe em instalações per manentes e quaisquer edificações, ressalvado o disposto no artigo 10.

Art. 10 - Nas áreas ou faixas de $1^{\text {a }}$ categoria ou de maior restrição somente são permitidos serviços, obras e edificações destinados à proteção dos mananciais, à regularização de vazões com fins múltiplos, ao controle de cheias e à utilização de águas prevista no artigo $8^{\circ}$.

Parágrafo único - permitida, observado o disposto no parágrafo único do artigo $3^{\circ}$ da Lei Estadual $n^{\circ} 898$, de 18 de dezembro de 1975, a construção de ancoradouros de pequeno 
porte, rampas de lançamento de barcos, praias artificiais, pontões de pesca e tanques para piscicultura.

Art. 11 - Nas áreas ou faixas de $1^{\text {a }}$ categoria ficam proibidos o desmatamento, a remoção da cobertura vegetal existente e a movimentação de terra, inclusive empréstimo e botafora, a menos que se destinem aos serviços, obras e edificações mencionadas no artigo 10 .

Art. 12 - Nas áreas ou faixas de $1^{\text {a }}$ categoria não permitida a ampliação de serviços, obras e edificações já existente, que não se destinem às finalidades definidas no artigo 10, bem como a ampliação ou intensificação dos processos produtivos de estabelecimentos industriais existentes.

Art. 13 - Nas áreas ou faixas de $2^{\circ}$ categoria são permitidos, observadas as restrições desta lei, somente o seguinte usos:

I - residencial;

II - industrial, de acordo com a relação das indústrias permitidas pela Companhia Estadual de Tecnologia de Saneamento Básico e de Defesa do Meio Ambiente - CETESB, para exercer atividades nas áreas de proteção dos mananciais da Região Metropolitana;

III - comercial, com exceção do comércio atacadista;

IV - de serviços e institucional, com exceção de hospitais, sanatórios ou outros equipamentos de saúde pública, ressalvados os destinados ao atendimento das populações locais e desde que não sejam especializados no tratamento de doenças transmissíveis;

V - para lazer;

VI - hortifrutícola;

VII - para florestamento, reflorestamento e extração vegetal.

Art. 14 - Nas áreas de Classe A, somente serão admitidos parcelamento, loteamento, arruamento, edificação, reforma, ampliação de edificações existentes, instalação de estabelecimentos, alteração de uso ou qualquer outra forma de ocupação, se satisfeitas as seguintes exigências:

I - quota ideal de terreno por unidade residencial, comercial, industrial, de serviços e institucional de, no mínimo, $500 \mathrm{~m}^{2}$;

II - máxima Densidade Bruta Equivalente (Dbeq) de 50 ocupantes equivalentes por hectare; 
III - índices urbanísticos constantes do Quadro II, anexo a esta lei.

$\S 1^{\mathrm{o}}$ - O inciso II não se aplica, isoladamente, a imóvel destinado a uma residência unifamiliar, bem como a estabelecimentos comerciais e industriais.

$\S 2^{\circ}$ - Na ocupação de qualquer lote de terreno, deve permanecer obrigatoriamente sem pavimentação e impermeabilização uma extensão de terreno não inferior a $20 \%$ da área total do lote.

Art. 15 - Para efeito desta lei, o cálculo da Densidade Bruta Equivalente (Dbeg) será feito mediante a aplicação das fórmulas constantes do Quadro III, anexo.

Parágrafo único - Na aplicação das fórmulas constantes do Quadro III, anexo, o número de empregos industriais será calculado com base nas quotas da área construída por emprego, constantes do Quadro IV, anexo.

Art. 16 - Nas áreas de Classe B e C, ressalvado o disposto no artigo 17, somente serão admitidos parcelamento, loteamento, arruamento, edificações, reforma, ampliação de edificações existentes, instalação de estabelecimentos, alteração de uso, ou qualquer outra forma de ocupação, se satisfeitas as seguintes exigências:

I - índices urbanísticos constantes dos Quadros V e VI, anexos;

II - Densidade Bruta Equivalente (Qbeq) constante do Quadro VII, anexo;

III - Quota Bruta Equivalente (Qbeq) de terreno por unidade de uso residencial, constante do Quadro VIII, anexo.

$\S 1^{\circ}$ - O cálculo da Densidade Bruta Equivalente (Qbeq) será feito na forma artigo anterior.

$\S 2^{\circ}$ - O cálculo da Quota Bruta Equivalente (Qbeq) de terreno por unidade de uso residencial, será feito mediante a aplicação das fórmulas constantes do quadro IX, anexo.

$\S 3^{\circ}$ - Na ocupação de qualquer lote de terreno, as percentagens da área do lote que devem permanecer sem pavimentação e impermeabilização serão, obrigatoriamente, não inferiores a:

1 - 30\% nas áreas e faixas de Classe B;

2 - $40 \%$ nas áreas e faixas de Classe C.

Art. 17 - Os parcelamentos, loteamentos, arruamentos, edificações, reformas, ampliações de edificações existentes, instalações de estabelecimentos, alterações de uso ou quaisquer 
outras formas de uso em glebas ou terrenos que compreendam área de $2^{\circ}$ categoria, Classe $\mathrm{C}$, e de $1^{\circ}$ categoria de que tratam o inciso $\mathrm{V}$ do artigo $2^{\circ}$, gozarão de bonificações, sendo a máxima Densidade Bruta Equivalente (Dbeq) admissível, calculada multiplicando-se os valores, constantes do Quadro VII, pelo fator de bonificação «f», determinado com a aplicação da expressão constante doe Quadro III.

$\S 1^{\circ}$ - Os valores mínimos de Quota Bruta Equivalente (Qbeq) por unidade de uso residencial para esses empreendimentos serão obtidos dividindo-se os valores constantes do Quadro VIII, pelo fator de bonificação «f» referido no «caput» deste artigo.

$\S 2^{\circ}$ - Nos empreendimentos a que se refere a que este artigo o valor máximo admissível do coeficiente de aproveitamento será o menor dentre os dois seguintes:

1. o valor dado pela aplicação da expressão constante do Quadro VI;

2. 4,9 (quatro inteiros e nove décimos).

$\S 3^{\circ}$ - O valor máximo do índice de elevação 4 (quatro).

$\S 4^{\circ}$ - A aplicação das bonificações previstas no "caput" deste artigo fica condicionado à prévia adequação das áreas cobertas de mata e de todas as formas de vegetação primitiva a um dos seguintes regimes:

1. vinculação obrigatória aos empreendimentos correspondentes, limitado o seu uso às restrições referentes à área de $1^{\mathrm{a}}$ categoria;

2. doação ao Estado, sob condição de destinação específica;

3. doação ao Estado, ficando este autorizado a conceder, com a anuência do doador, o direito real de uso sobre as áreas, nos termos artigo $7^{\circ}$ do Decreto-Lei Federal $n^{\circ} 271$, de 28 de fevereiro de 1967 , e obedecidas as restrições referentes às áreas de $1^{\circ}$ categoria.

Art. 18 - Nas áreas de exploração hortifrutícola, de florestamento, reflorestamento e nas destinadas à extração vegetal deverão ser, também, observadas as normas de proteção e conservação do solo definidas pela Secretária da Agricultura.

Art. 19 - A remoção indispensável da cobertura vegetal somente será permitida, obedecida a legislação em vigor e mediante aprovação da Secretaria da Agricultura, após prévia manifestação favorável da Secretaria dos Negócios Metropolitanos, nos seguintes casos:

I - para implantação das obras e serviços admitidos nesta lei; 
II - para a exploração hortifrutícola, florestamento, reflorestamento e extração vegetal, em regime de utilização racional, ou para substituição por vegetação com finalidades estéticas, recreativas ou de proteção.

Art. 20 - As obras que exijam movimentação de terra deverão, sem prejuízo de outras exigências, se executadas seguindo projeto, que assegure a proteção dos corpos de água contra ou assoreamento e a erosão, a ser aprovado pela Secretaria dos Negócios Metropolitano.

Parágrafo único - Os locais preferenciais de escoamento de águas pluviais deverão ser adequadamente protegidos por obras contra a erosão.

Art. 21 - A alteração, ampliação intensificação dos processos produtivos de estabelecimentos industriais, relacionados entre os permitidos pela CETESB em áreas de proteção de mananciais, despedem da prévia aprovação prevista no parágrafo único do artigo $3^{\circ}$ Lei Estadual n ${ }^{\circ}$ 898, de 18 de dezembro de 1975.

Art. 22 - Os sistemas públicos de abastecimento de água e de esgotos sanitários atenderão somente às áreas e faixas de Classe $\mathrm{A}$ e $\mathrm{B}$, ressalvados os existentes até a data da publicação desta lei.

Art. 23 - Os efluentes dos sistemas públicos de esgotos sanitários deverão ser afastados das áreas de proteção.

$\S 1^{\circ}$ - Quando na bacia receptora não houver sistema de esgotos adequados, os efluentes a que se refere este artigo deverão ser previamente tratados, de acordo com as exigências da CETESB.

$\S 2^{\circ}$ - Nos casos em que o afastamento e o tratamento forem inviáveis, somente será permitida a disposição de efluentes de sistemas públicos de esgotos nas áreas de $2^{\mathrm{a}}$ categoria e desde que recebam o tratamento mais conveniente dentre um dos dois seguintes:

a) tratamento biológico e desinfecção do efluente;

b) tratamento a nível primário, no mínimo, seguido de infiltração ou irrigação subsuperficial, assegurada a proteção do lençol freático.

$\S 3^{\circ}$ - Nos casos referidos no item 1 do parágrafo $2^{\circ}$, o número mais provável de coliformes o fixado pelos padrões de balneabilidade estabelecidos pelo órgão federal competente.

$\S 4^{\circ}$ - A CETESB poderá estabelecer limites à concentração de nutrientes nos efluentes, nos casos em que o manancial manifeste tendências à eutrofização acelerada, caracterizada por 
desenvolvimento de vegetação macro ou microscópica prejudicial à utilização da água, conforme referido no artigo $8^{\circ}$.

$\S 5^{\circ}$ - Na eventualidade de o órgão responsável deixar de atender ao disposto neste artigo, poderá o Estado assumir os sistemas de saneamento básico para adequá-los às normas desta lei.

Art. 24 - Os sistemas particulares de esgotos não ligados ao sistema público deverão ser providos, pelo menos, de fossas sépticas, construídas segundo normas técnicas em vigor, com seus efluentes infiltrados no terreno através de poços absorventes ou irrigação subsuperficial, assegurando-se a proteção do lençol freático.

$\S 1^{\circ}$ - Nas áreas não servidas por sistemas públicos de esgotos sanitários ou de abastecimento de água, a distância mínima entre o poço ou outro sistema de captação de água e o local de infiltração do efluente de fossa séptica será, no mínimo, de 30 metros, independentemente da consideração dos limites das propriedades.

$\S 2^{\circ}$ - Os projetos de loteamentos, edificações e obras, bem como os documentos para licenciamento de atividades hortifrutícolas, de florestamento, reflorestamento e extração vegetal, deverão indicar a localização das captações de água e das fossas sépticas.

$\S 3^{\circ}$ - Os projetos de edificações e obras deverão ainda conter os projetos detalhados da fossa séptica ou de outro processo de tratamento, desde que aprovado pela CETESB, e do sistema de infiltração do seu efluente.

Art. 25 - Nas áreas de proteção delimitadas no artigo $1^{\circ}$ não será permitida a disposição de resíduos coletados por sistemas de limpeza pública, bem como do lado resultante dos processos de tratamento dos sistema público e particular.

$\S 1^{\circ}$ - Nas áreas onde não existem sistemas públicos de coleta de lixo:

1. os resíduos sólidos decorrentes das atividades industrial, comercial ou de serviços deverão ser removidos para fora das áreas de proteção;

2. os resíduos sólidos decorrentes da atividade residencial, desde que não removidos para fora das áreas de proteção, deverão ser enterrados.

$\S 2^{\circ}$ - Nas áreas de $1^{a}$ categoria não serão permitidos a disposição e o enterramento de resíduos sólidos:

Art. 26 - No pedido de licenciamento das atividades hortifrutícolas, a ser apreciado nos termos do parágrafo único do artigo $3^{\circ}$ da Lei Estadual nº 898, de 18 de dezembro de 1975, 
o interessado deverá identificar e caracterizar a área a ser cultivada, fornecer a relação dos fertilizantes e defensivos agrícolas a serem empregados, especificar os meios a serem utilizados para o descarte de resto de formulações e de embalagens e os meios de disposição dos efluentes líquidos da lavagem dos equipamentos e recipientes usados. $\S 1^{\circ}$ - As dosagens admissíveis de fertilizantes agrícolas serão fornecidas pelo órgão competente da Secretaria da Agricultura.

$\S 2^{\circ}$ - Não serão permitidas as culturas que exijam uso intensivo de defensivos agrícolas, a critério da Secretaria da Agricultura.

Art. 27 - A CETESB poderá exigir do usuário a redução da área cultivada, se as condições dos mananciais assim o impuserem, em razão dos níveis de eutrofização, toxidez e nocividade.

Parágrafo único - O uso de defensivos agrícolas deverá se restringir ao mínimo indispensável, podendo a CETESB, de comum acordo com a Secretaria da Agricultura, proibir o uso de tais defensivos, se os níveis de contaminação verificados no corpo de água atingirem limites inaceitáveis.

Art. 28 - Nas áreas de proteção não será permitido, para a distribuição de defensivos agrícolas, uso de aeronaves ou de equipamentos que utilizem correntes de ar a altas velocidades.

Art. 29 - As quantidades, armazenáveis nas áreas de proteção, de quaisquer produtos químicos que possam colocar em risco a qualidade das águas, serão determinadas segundo os critérios estabelecidos pela CETESB.

$\S 1^{\mathrm{o}}$ - O transporte, o armazenamento e a manipulação dos produtos referidos neste artigo obedecerão às normas de segurança a serem fixadas pela CETESB.

$\S 2^{\circ}$ - Os órgãos de segurança pública, responsáveis pela operação de canalizações ou equipamentos de transportes nas áreas de proteção, comunicarão à Secretaria dos Negócios Metropolitanos e à CETESB acidentes que envolvam dispersão de produtos químicos.

Art. 30 - As instalações particulares de tratamento e disposição de esgotos, a que se refere o artigo 24, deverão estar em operação no prazo máximo de 3 (três) anos, a partir da data da publicação desta lei.

Art. 31 - Os hospitais, sanatórios ou outros equipamentos de saúde pública existentes na área de proteção, que efetuem tratamento de doenças infecto-contagiosas, deverão ser transferidos para fora das áreas de proteção, no prazo máximo de 5 (cinco) anos, a partir da data da publicação desta lei. 
Art. 32 - Os imóveis existentes nas áreas ou faixas de $1^{a}$ categoria poderão ser desapropriados, caso fique demonstrada a inexistência ou insuficiência de sistema público de esgotos para receber seus efluentes líquidos, conforme o disposto no artigo 23.

Art. 33 - As indústrias localizadas nas áreas de proteção deverão apresentar à CETESB, no prazo máximo de 1 (um) ano, a partir da data da publicação desta lei, projetos de disposição de seus efluentes líquidos que prevejam, prioritariamente, o seu afastamento para sistemas de esgotos de bacias não protegidas.

$\S 1^{\mathrm{o}}$ - Na impossibilidade de afastamento referido neste artigo, os projetos deverão prever tratamento aprovado pela CETESB, assegurada a disposição dos efluentes nas áreas

$\S 2^{\circ}$ - As obras de disposição dos afluentes a que se refere este artigo deverão estar concluídas no prazo fixado pela CETESB para cada caso, após a aprovação, por esta, do respectivo projeto.

$\S 3^{\circ}$ - Na hipótese de ficar demonstrada a impossibilidade de serem implantados os sistemas de tratamento e disposição de que trata este artigo, a CETESB poderá recomendar à Secretaria dos Negócios Metropolitanos a desapropriação da indústria.

Art. 34 - Vetado

Art. 35 - Vetado

Art. 36 - A Secretaria do Negócios Metropolitanos utilizará os serviços técnicos da Empresa

Metropolitana de Planejamento de Grande São Paulo S/A - EMPLASA, unidade técnica dos Sistema de Planejamento e Administração Metropolitana, nos termos da Lei Estadual Complementar $n^{\circ}$ 94, de 29 de maio de 1974, para o desempenho das atribuições que lhe são conferidas por esta lei.

Art. 37 - A execução das normas desta lei se fará sem prejuízo da observância de outras, mais restritas, previstas em legislação municipal.

Art. 37 A - Acrescentado pela Lei Estadual n 11.216, de 22 de julho 2002

Art. 38 - Esta lei entrará em vigor na data de sua publicação.

Palácio dos Bandeirantes, 17 de novembro de 1976.

PAULO EGYDIO MARTINS 
A ASSEMBLÉIA LEGISLATIVA DO ESTADO DE SÃO PAULO, decreta e eu, Natal Gale, na qualidade de seu Presidente, promulgo nos termos do $\S 4^{\circ}$ do artigo 26 da Constituição do Estado, os seguintes dispositivos da Lei n ${ }^{\circ} 1.172$, de 17 de novembro de 1976, da qual passam a fazer parte integrante:

Art. 34 - Mantido o veto.

Art. 35 - O Governador do Estado, através da Secretaria dos Negócios Metropolitanos, reservará, mediante as medidas administrativas cabíveis, segundo um programa a ser fixado por decreto e a iniciar-se em 1977, em cada uma das áreas de proteção de que tratam o artigo $2^{\circ}$ da Lei Estadual $n^{\circ} 898$, de 18 de dezembro de 1975, e o artigo $1^{\circ}$ desta lei, no mínimo $0,5 \%$ de suas respectivas áreas de proteção para implantação de parques metropolitanos situados junto aos corpos de água principais e destinados ao esporte, ao lazer e à recreação da população.

Assembléia Legislativa do Estado de São Paulo, aos 30 de março de 1977.

NATAL GALE, Presidente 